\title{
BLANCAN MAMMALS FROM HAILE XVA, ALACHUA COUNTY, FLORIDA
}

By

JESSE STEADMAN ROBERTSON, JR.

\begin{abstract}
A DISSERTATION PRESENTED TO THE GRADUATE COUNCIL OF THE UNIVERSITY OF FLORIDA

IN PARTIAL FULFILLMENT OF THE REQUIREMENTS FOR THE DEGREE OF DOCTOR OF PHILOSOPHY
\end{abstract}

UNIVERSITY OF FLORIDA

1970 


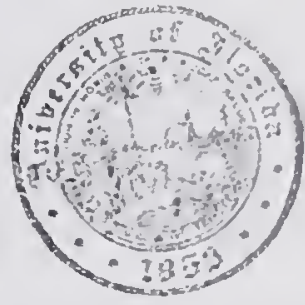

UNIVERSITY OF FLORIDA

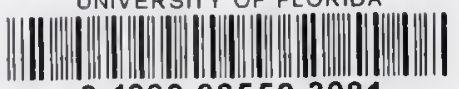

31262085523081 
To Shirley 


\section{ACKNOWLEDGMEINTS}

Fossil material was examined from the Amurical liusumi of Natural History, the university of californja Museum of palcontologý, the Plorida state Musem, and the university of Kansas. I wish to thark the persons in cluruge of these collections for the opportunjty to study the retexjas in their care, and to adrnowledge the excellent work of Mr. Russcll parks in preparing the plates.

I also wish to thank Dr. S. David Wob?, Dr. I. Y. Patton, and Dr. H. K. Brooks for liejr encouragement aud help during the course of this study. 
THBLE OF CONIFNTS

Pric

ACKNOWLEIGMENIS . . . . . . . . . . . . . . . ili

IIST GE MABTES. . . . . . . . . . . . . . . Vi

ITSI OF FTGURES • • • . . . . . . . . . . . . . viii

ABBREVIATTONS . . . . . . . . . . . . . . . $x$

ABSTRACT. . . . . . . . . . . . . . . . . . . xi

INTRODUCTION。 . . . . . . . . . . . . . . . . . 1

GEOIOGY . . . . . . . . . . . . . . . . . . . 6

SYSTIMATIC PALEONTOTOGY . . . . . . . . . . . . . . . î

Oräer isectivora

Eryptois parva............ io

Scalopus agnacicus. . . . . . . . . . . J

Oraer Ecientata

Glossolnerium cherpaomalessis. . . . . . . 13

Krogitevichia paranersis. . . . . . . . . $\$ 1$

Review of the chamythexinde. . . . 55

Prolution of the ciliamytheses. . . . 60

Dasrpus gellus. . . . . . . . . . . . 68

Order tragomirpha

SyIvilagus sp. . . . . . . . . . 78

Order Rodentia

Petauria sp. . . . . . . . . . . 79

Castor canaderisis . . . . . . . . . . . 87

Signodon medius . . . . . . . . . . . 88

Order canivora

Cantalars.................. 90

peronima s!. . . . . . . . . . . 96

Smícoon gracitis . . . . . . . . . . 95 
Page

Orcier Prohoscjaca

Gomphotherjicise . • . • . . . . . . . 97

Order perissocactỹa

Namnippn phterrn . . . . . . . . . . . . 99

plesippus simpljicidens. . . . . . . . . . 99

Equus (1Dinus) sp. . . . . . . . . . 109

rapirus $\mathrm{sp}$.

oxder Arsiogaciyla

Mylohyus floridanus . . . . . . . . . 11 l.

Iemjauchenia CI macrocephala. . . . . . . 117

ociocoi?eus virginjanus. . . . . . . . 122

AGE AND CORRETATION . . . . . . . . . . . . . . 127

PALEOLCOLOGI. . . . . . . . . . . . . . . . 135

ZOOGEOGRAPIY. . . . . . . . . . . . . . . . 140

SUMMARY • . . . . . . . . . . . . . . . . . 14

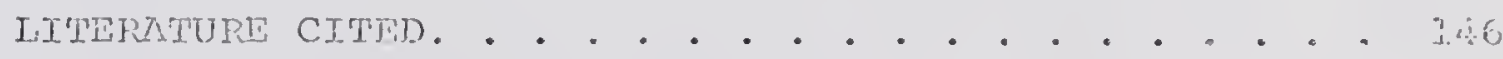

BIOGRAPHICRT, SITTTCII . . . . . . . . . . . . 15\% 


\section{LIST OF TABLES}

Table

Page

I Nammalian Faunal List and Minimum Number

of Individuals . . . . . . . . . . . 1 l.

2 Measurements (in mu) of the Lower Deritition

and Mandible of UI I7466 aid Other Fowsil

and Recent Cryptolis parvą....... . 12

3 Measurements (in ma) ot the Uppex ard Loivi:

Dentitions of Three Species of GJosso--

therjum. . . . . . . . . . . . . 24

4 Limb Measurements (in nm) of Glossothexium

chapadmalensis and Glossotherium FarIoni. 26

5 Measurements (in mm) of the Bones of the

Manus and Pes of Glossothcrium chaparmalcns:

From Haile XVA and Glossotherim hanlani . 28

6 Cranjal and Dental Measurement: (in mn) of

Kraglievichia and Chlamytieniun. . . . . . 39

7 Measurements (in mn) of i.imb jements of

Kragijcvichia paranensis, U1: 30902.

Haile XVA. . . . . . . . . . . . . 16

8 Measurements (in mm) of timb Elemants of

iracilevichia paranensis Prom Various

Florida Localities . . . . . . . . . . 53

9 Dental Measurements (in mu) of Dasypis

bellus . . . . . . . . . . . . . 3

10 Mocurements (in mm) of the Femora of

Fosil and recent rastor canadensis. . . = 89

11 Dental Measurenents (in mm) of Sionodon

merane arri sigmodun minor. . . . . . . . 9j 
Iable

Page

Measurcments (in min) of the Mumerus of

Fossil and Recont ptcronusa anci Recent

Intra. . . . . . . . . . . . . 96

13 Measurcments (in won) of the Astragali of

Smilodon gracilis From llaile $x V A$ and

Port kennedy . . . . . . . . . . . 98

14 Measuremonts (in mm) of Nannippus phlegon

Cranial and Postcranial Matcrial Irrom

Haile XVA. . . . . . . . . . . . 102

15 Measurements (in $\mathrm{mm}$ ) of the Upper Dentition

of Plesippus simpljcidens From Haile $X V \lambda$. . 106

16 Measurements (in mm) of Plesippus simpiciaens Postcranial Material From Iajle XVI . 107

17 Measuremonts (in mu) of Equus (Asinus) sp.

Cranial and Postcranial Material From

Hajle XVA. . . . . . . . . . . . 110

18 Measurements (in mm) of the ventition of Mylohyus floridanus. . . . . . . . . 1]6

19 Measurements (in $\mathrm{mm}$ ) of the Upper Dentitjon of Hemiauchenia cf macrocephala From IIajile XVA. . . . . . . . . . . . . 12.2

20 Measurements (in mm) of Postcranial Elements of Odocoilcus virginianus From Scveral Florica Pleistocone Localities . . . . . . 125

2] Faunal Comparjsons or maile XVA and olher P.lancan Localities . . . . . . . . . . 129 
LIST OP FTGURES

Figure

Page

1 Geologic Sectjon at Haile XVA. . . . . . . 8

2 Glossotherium chapadmalensis Upper bentition. . . . . . . . . . . . 16

3 Glossotherium chapadmalensis Right Mandible, Lateral View . . . ..... 19

4 Glossotherium chapacmalensj.s Right Mandible, Occlusal View. . . . . . . . 21

$5 \quad$ Kraqlievichia paranensis Cranial Materiai. . 34

6 Kraglievichia paranensj.s Front Iimb

Elements............... 42

$7 \quad$ Kraglievichia paranensis Himd Ij.mb

Elements............... 48

8 Kraglievichia and Chlamytherium Calcanea . \$1

9 Kraglievichia and Chlamytherjum Femora. . . 62

10 Kraglievichia and Chlomytheriun Dermal Plates........... . . 64

11 Dasypus bellus Mandible. . . . . . . . . .

12 Dasypus bellus Astragali . . . . . . . 75

13 Petauija sp. Right Mandible. . . . . . 8?

14 Petauria sp. Kight $M_{3} \cdot$. . . . . . . . 84

15 Ptcronura Humerns. . . . . . . . . . 94

16 Namijpiss pli egon Upper Volar....... 101 $v i \dot{i}$ 


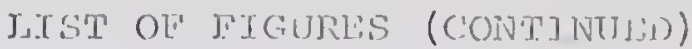

Fiquire

17

18

19

20

Plesippus simplicians Upjer Jentition . . 105

My Johyus floridanus Manaibulatr Ramus . . . 113

Mylohyus florjaanus Mandjbular Symphysis . 115

Iremianchenia of ruacrocephatiz Upper

Dentition. . . . . . . . . . . . . 11? 


\section{ABBREVIAITONS}

Abbreviations of institutions and collections useä throughout this work are as follows:

AMNH: American Museum of Natural History

U.C.M.P.: University of CaIifornia Nuseum of Paleortology

UF: University of Florida collections

UK: University of Kansas

H.C.T.: University of Houston Collection 
Abstiact of Disscrtation presented lo the Graduale Council of the University of Jior.ica in partial fulfillment of the Recuironents for the Degrec of Doctor of philosophy

BIANCAN MAMRAJS FROM HATLE XVA, ALACLUZA COUWTY, FIORTDA

\section{BY}

Josse Steadman Robortson, Ir.

Jecember, 1970

Chairman: Dr. S Davia Webb

Major Department: Zoology

The IIaile XVA fauna is the first GuJf Cocel=1 Plain Blancan

fauna to be described. Amoug the mamais, winich are represented by 8 orders, 17 families, and 18 genera, arc two edentates which are new to the North American fauna. Grissotherjum shapadmalensis (Kraglierich), a small souih

American ground slotin species, is reported from North America for the first time. This species was provious? Knoin from tlı Chapadmalalan (early pleistocene) taruna of Argenitia. It is proposed that this form may be ancostril

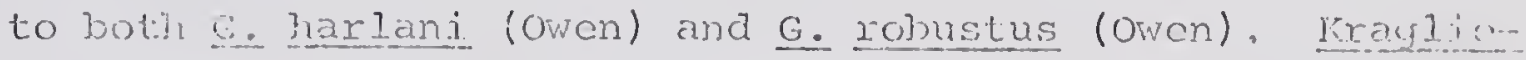
vichir paranchsis (Kragliovich), a giant, extinct ainasila previously Janorns only from Miocene and Pliocene deposits of South imcriec, is reported for the fijst: time in Nowh Amorica. The naije XVA spocimen is ciescuiber. as a now sub-

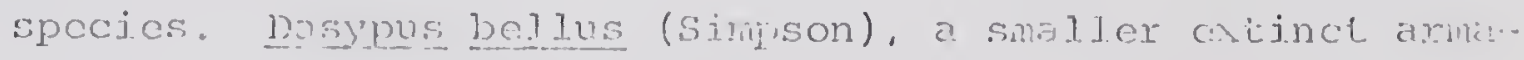
diljo, is reloutech roy the fjust time in the Blancan, maxk-

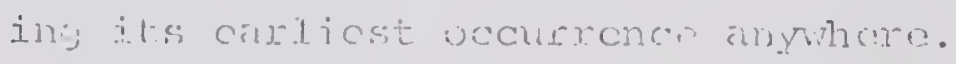


A brief review of the Subfamily chlamytheriinae is presented, and it is suggested that plaina (Castellanos) is a synonym of Kraglievichia (Castellanos) and that Hoffstetteria (Castejlanos) is a synonym of Chlamythexiun (Iund). Chlamytheres are shown to have been present in North Anerica continuously since the re-establishment of the late cenozoic land bridge between North and South America, and it is proposed that the pleistocene evolution of these forms occurred simultaneously on both continents.

Whe old world flying squirrel petauria is reported for the first time in the New world. It was previously known only from carly Pleistocene deposits of Bavaria.

Several of the Hajle XVA taxa are closely allied with

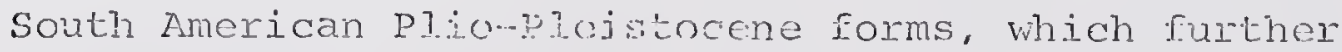
strengthens the previcus?y established correlation between the Chapadmalalan stage of South America and the Blancan stage of North America.

The abundance of acjuatic non-maninalian vertebrates inaicates that the environment of deposition was probabiy an open stream. The mammalian members of the terrestrial communty include the tropical or subtropical indicators Kraglievichia and Dasypus. Forcst indicators include Mychyns, Castor, Petaujja, and Glossotherium. The zoogeography of the more exolic foms is discussed. 
T.NTRODUCI:AON

Furida has long been famous for its pleistocone fossil vertebritc deposits. Most of these sjtes have yjelded faunas representing the later stages of the plojstocene. Classical cxamples of these are Vexo, Injian Rivor County (Sellaxds, 1917; 11ay, 1917; 1928; Wiegel, 1962), Melbourne, Brevard Comty (see Ray, 1957, for numerous references), and Scminole Field, pinellas County (Simpson, 1930) which are all of late Rancholabrean age. Among the slightly carlier Rancholabrean famas are Haile VIIIA, Alachua County, and Brajenton, Manatee County (Robertson, in press). An Irvingtonian site, Coleman IIA, Sumter Couriy, has recentiy been described by Martin (in pyess). To date, thjs is the enxliest Florida Pleistocene famna to be fully described. Another excellent Irvingtonian fauna, Inglis IA, Citrus county, is present]y being described by Mr. Jean rlein, a gradiaic student in geology at the Univexsjly of Floxiáa. The Sonte Fe T locality, Gilchrist county, has long buen considereh to be of s? arcan age, blit the famna is is

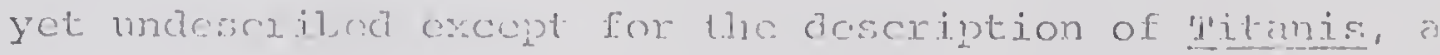


giant, flightless birá (Broblsorb, 1963). A faunal list fnr this locality is provided by Weblo (in pressa). Other Florida deposits which are considered to be of Blancan age, but which have not been studied, are Santa Fe IV and Santa Fe VITI, Gilchrist County.

Correlatjon of Florida Pleistocene deposits is diffi-cult at best, because of their mode of deposition. The two most common types of Florida Pleistocene fossil vercebraie deposj.ts are filled sinkholes in limestone and river bottom deposits. The various fissure fillings have trapped sediments representing many stages of the pleistocene, and adjacent sintholes may contain faunas which vary greatly in age. River bottom deposits are usually heterochronous accumulations of bones which have exoded out of fossilfeious strata and setiled at low energy areas of the stream. This lack of oxderly stratigraplite sequences for most of the Florida fossjl vertebrate deposits necessitates the use of faunal correlation.

Usually, a reasomably accurate age assignment can be made pasca upon tha presence or absence of certain genera and srecies. The prosence of Bison, for erample, indicatos a Rancholabrean arje (Savage, 1951). Further refinement of the age could be made by detcrmining the species of Bison prescni. The jockence of De Iotifrons would represent early 


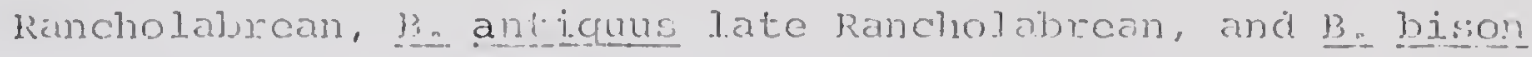
sub-Recenti OI Receni (Rcherison, in press).

In adcition to fimma]. corredation, line effects of sco level changos due to Ploistocone glaciculion mey be cuployed as an aid to dating Plorida Plcistocene deposjts. Giacial eustatic fluctuatjons of sea leve? have causcd "tomraces" or "abandoned shore lines" which are dorainant geonnglyi" features of the Florida landscape (Cocke, 1945; macheil, 1949; White, 1958; Alt and Brooks, 1965). The Iocation of a doposit relative to thesc structures can be quite helpful in age detemination. If, for cxample, a coastal terrestrial deposit is presently lying at or below sea levej, tren it must represent a time when sea level was as low or. lower than it is now. This would be an indication that dre de. posit was laid down during glacial times, as these vere tre times of low sea level. Once this is detcrmineà, fammit. clenonts will juricate whirh glacial stage is representex.

Inland deposits of hjghcr elevations present a probinn in thai they could have been deposileci during ojiber a glacial. or intorglacial stage. If, however, ji can he show lidel a paticular inland coposit was coastal at its time of dejositim, then it mint represent in interglanial stegs,

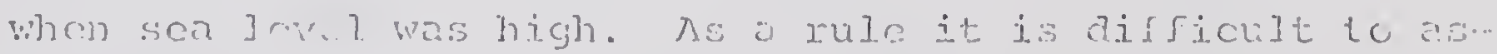

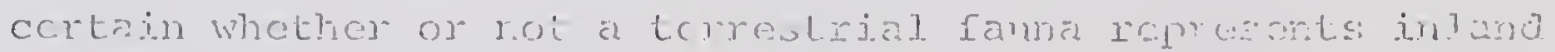


or near-shore condjtions. Auffenberg (1953), however, has been able to do this for certain aeposits. Working with fossil Termapene carolina, he has shown that particular intergradient populations of this species reflect nearshore conditions. If members of these intergradient populations are present in an inland deposit of higher elevation, the acposit probably represents an interglacial stage. Evidence for near-shore conditions is not a lways this conclusive, horvever, and sometimes one is forced to rely upon more tenuous means.

of particular interest among the plorià fossil vertebrate deposits are those near the settlement of Haile. Alachua County, convenientiy located only 15 miles from the University of Florida campus. In a radius of only a mile sue clustered numerous vextebrate localities, traditionaly designated by roman numerals in the university of Florida vertebrate palcontology collections. Most of the Haile localities have procluced fossils of Rancholabrean age. Notable exceptions to this are localities $V$ and VI which are considered to be Pliocene (Auffenberg, 1955) and locality גith which is regarded as Blarcan. The fossil vertebrate assemislage recovered fron the Jaile XVA locality constitutes the subject jor this dissertation.

The Haile yin locality is situated on the property of 
pátzc. Broincis's Jimestono Prociucts, Inc., neax llaile, Rl7k, T95, S25, Mlachua County, Florjada. It was discovered in 1964 by Mr. Phillip Kinsey of Jacksonville Beach, florida. who has long becn a friend of, and a contributor te, the Florida Statc Muscum. Mr. Kinsey did extensive collecting at Haile XVA, and, upon recognizing it as an umusual locality, brought it to the attention of the museum staff. Further crcavations wcre corricd out in the same year by Dr. S Duvid Webb, Mr. Robert Allen, and the present author, with the support of NSI Grant GB 3862. The resulting collections, in addition to the large quantity of bones so generously donated by Mr. Kinsey, are now housed in the University of Florida collections.

In addition to the mammalian fauma described in tis is report, tive locality has also contributed extensive fisl anc? reptjie faunas. A fair anount of amphibian and aviin remoins is also proscrt. Among the reptiles are the type and abundant miterial of Chrysemys platymarginata (Weaver and Roberison, 1967 ). 


\section{GLOLOGY}

The faile XVA deposit, lying at an elevation of about 90 feet above sea level, is a filled sinkhole in the ocala (Eocene) Limestone. The deposit extends approximately 30 feet along its east-west axis; its north-south aimension is narrower and irregular in width.

Underlying the fossil-bearing matrix is a layer of darli brown, unfossiliferous hardpan which begins at a depth of approximately 20 feet and extends to a depth of at least six feet from its upper margin (Figure 1 ).

'the fossiz-bearing matrix extends from about five to 20 feet below present ground level, and consists of two units: an upper laycr of heavy, greenish clay; and an underlying layer of coarse, poorly sorted, graveliy sandstone, containing lenses of clay. Where these two units merge, an alternation of clay and sand lenses occurs. The lowermost massive sand is the most productive part of the fossilifcrous sequence. It contains much calcareous cement and calcareous cemented concretions. Many of the larger bones were cmrusted with cemented sand and gravel. The 


\section{Figure 1}

Geologic Section at Haile XVA

A. Sandstone alternating with gray clay

B. Heavy greenish alay

c. Coarse, poorly sorted, jraveliy sand... stone

D. Dark broviri hardpan

F. Ocala Iincstone (Eoccre) 
8

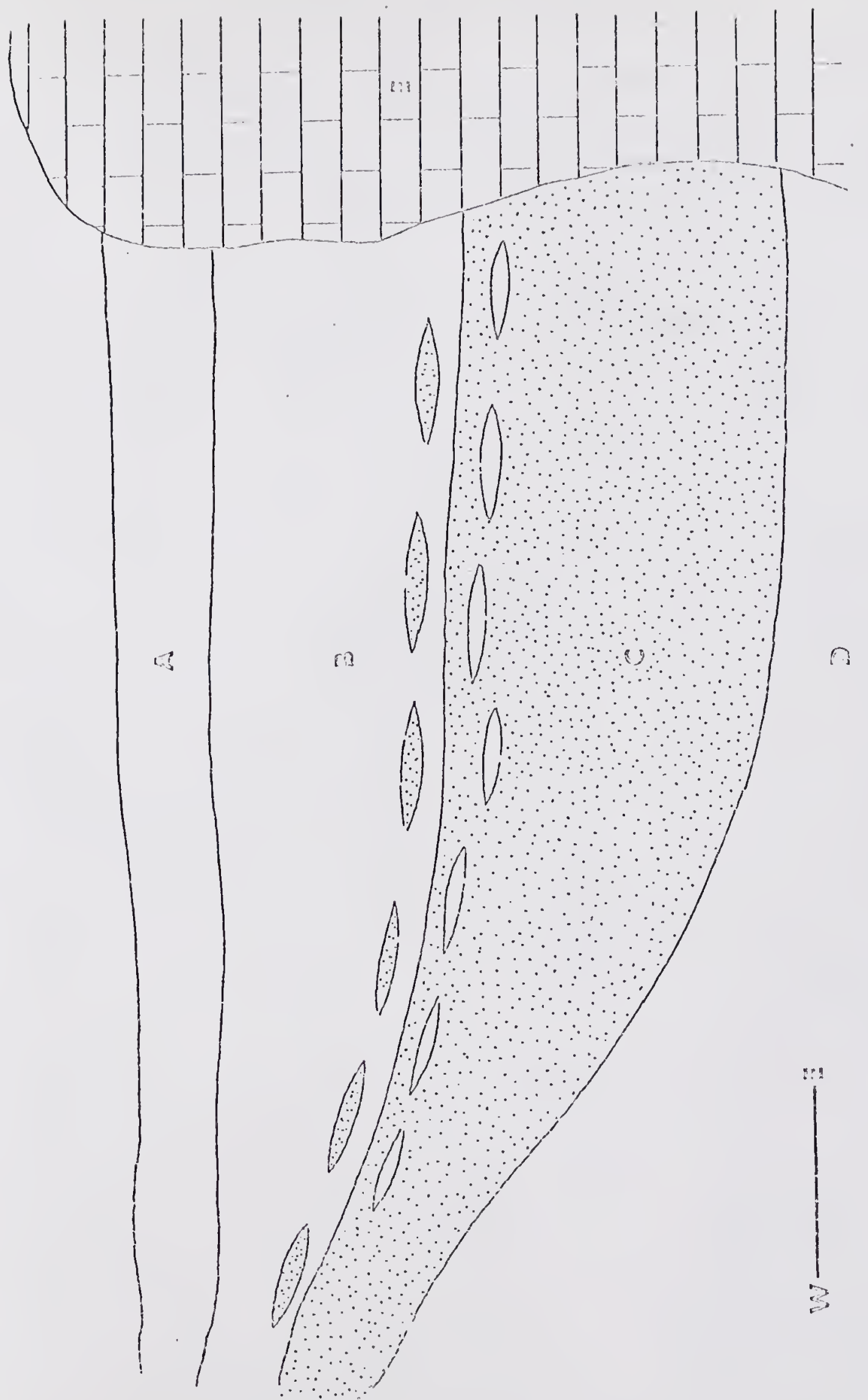


sandstone and clay were shown to be cssculially contempouaneous by the occurrence of fossils which extended from the sandstune up into the clay.

overlying the fossiliferous sand and clay seguence j.s a layer of thin, brown sandstome alternating with gray clay. This layer is unfossilj.ferous.

Since the original collections were nade, mining activities have scattcred the remaining matrix over a wide area. On a recent trip, for example, a tooth of Glossotherium belonging to the associated skeleton taken fron: the original deposit in 1964 was found on one of the adijacent piles of matrix. The sjte is presently covered by several seet of sand washed in from the cverhanging limc... stone ledge. There is little, if any, of the matrix remainjing in the original site. 


\section{SYSTEMATTC PATEONTOLOGY}

There are 20 taxa representing a minimum numer of 34 indiviariils in the Haile XVA fauna (Table 1). These are considered on the following pages.

Order Insectivora

Family Soricidae

\section{Cryptotis parva say}

Material: UF 17466, right mandible with $\mathrm{M}_{4}-\mathrm{M}_{3}$.

This specimen js morphologically indistinguishable fom specimens of C. parva from the Irvingtonian Coleman IIA and from recent specimens. The Haile XVA specimen is sligltiy larger than the previously mentioned specimers (Table 2), but not significantly so. T'he only other Blancan record of Cryptotis is tire Rexroad fauna (Hibbard, 1937, 1941), Meade County, Iezas。

Family raipidae

Scalopus acuaticus timnaeus 1758

Matexial: UF 37466,2 left $M^{2}$; If 17465. xight humerus. A comparison of the three Haile XVA specimens with corresponding modern is. aquaticus from the southeasterr. 


$$
\text { Talo?e } 1 .
$$

Manmalian Fambal List and Minimum Numbes: of Incividuals

Cryplolis parva

Scalopus aquatj.cus

Glossothexium chapadmalensis

Graqlievichia paranensis

Dasypus be]lus

Sylvilagus sp.

Petauria sp.

Castor canadensis

Sigmodon medius

Canidac

pteronura sp.

Smilodon gracilis

Gomplotheridiae

Nannippus phlegon

PICsippus simpljciciens

Equus (As.izus) sp.

Tapirus sp.

Mylohyus rloridarus

Memiauchenja cf macroccphala 


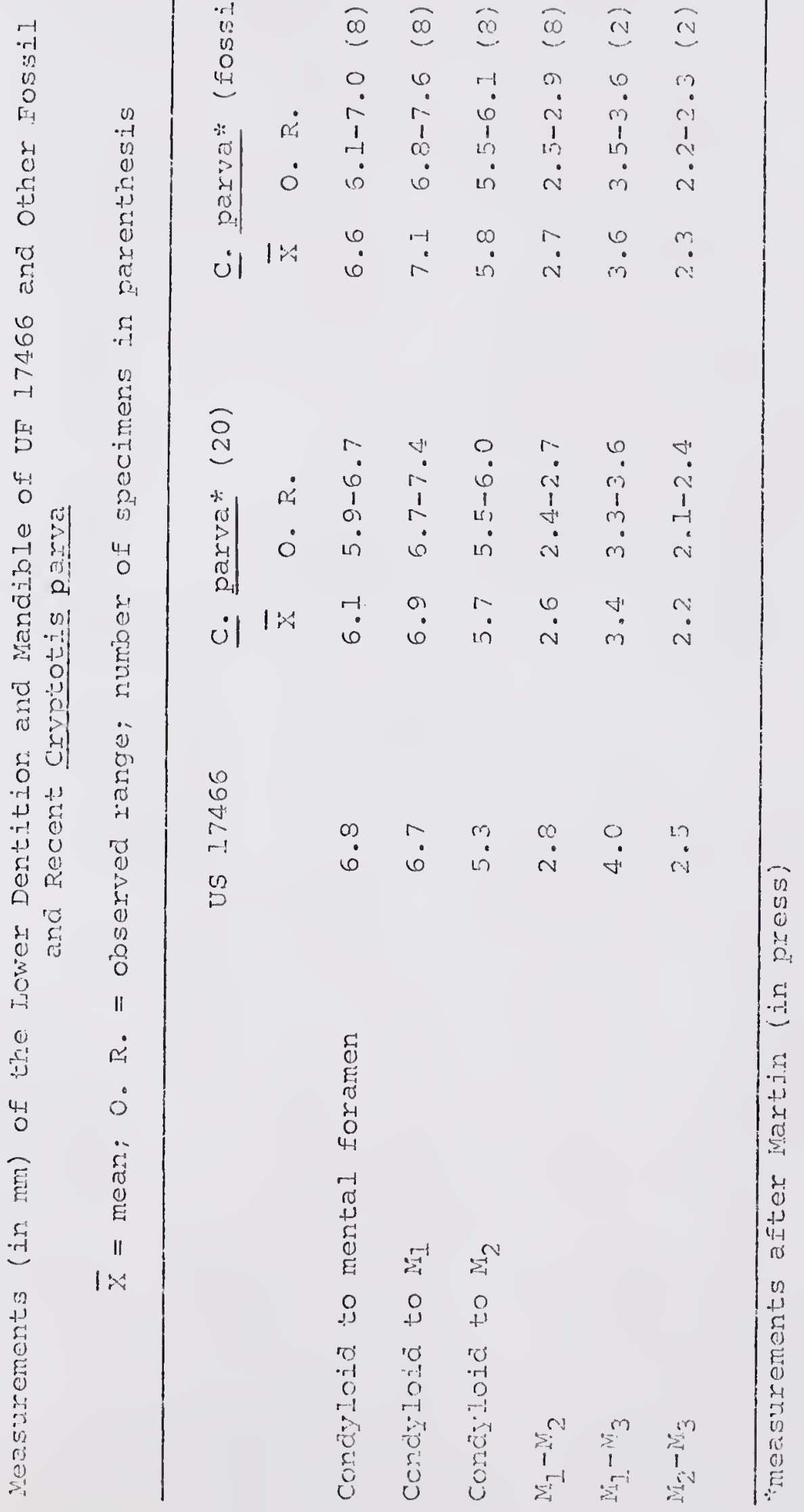


United stales roved ls no significant differmens in size or morpholegy.

Scalopus is also present in the Blancan Rexroad fauma of southwest kansas (Hibbard, 1941). The only other mole from the Rexroad fauma is Ilesperoscalops. Which is based upon a partial lowes dentition. A direct comparison could not be made with tris genus as only uppex tceth are known from Haile XVA. As Hibbard (194.L) points out, however, mole humeri of various genera can be distinguished from cne another, so it would be illogical to assume that a Scalopuslike humerus would belong to another genus. Because of this, and sjuce Scalopus is known from other Blancan and Irvingtonian deposits, it seems reasonable to ascribe this marLerial to the living species.

order Edentata

Family Mylodontidac

Glossothorium chapadmalensis

Kraglievich 1925

Naterial: Un 10922, partial skelcton

There is no donbt that the Haile XVA specimen represents one indiridual as there is no duplication of clements, and the left and right cloments agree very closely in all micosurcinonts. Parts of thiss specimen were collected by sevoral proic civer a mumer of years, but the bulk of the 
specimen was token from the sand layer of the fossiliferous sequence and was semi-articulated.

In the following discussion, terminology regarding sloth dentitions will be based upon that used by Hirschfeld and Weblo (1968): the first tooth (upper and lower) will be referred to as the caniniform; all the rest of the teeth will be referred to as molariform. No homologies are implied.

Upper dentition: The upper dentition of the Haile XVA specimen (Figure 2) is complete except for the left upper caniniform. The caniniform is triangular in cross-section and well developed. As in the Argentine specimen of $\mathrm{G}$. chapadnalensis, this stoutness of the caniniform is rew flected by the expansion of the anterior portion of the maxilla. The anterior portion of the maxilla is very much reduced in G. harlani, which tends to have a reducce or lost coniniform.

The first upper molariform tooth is large and oval in cross-section. As in G. harlani and G. robustus it is the longest anteroposteriorly of all the upper tectir, but j.s relatively narcow in transvelse diameter. Due to the very well-developed lower caniniform which in part occludes with this tooth, the anterior oblique vear surface is much more acentuater thit in $\underline{G}$ harlani. In several specinens of 
Figure 2

Glossotherium chapadnalensis Upper Dentition $\mathrm{X} 1.13$ (Iinear; 


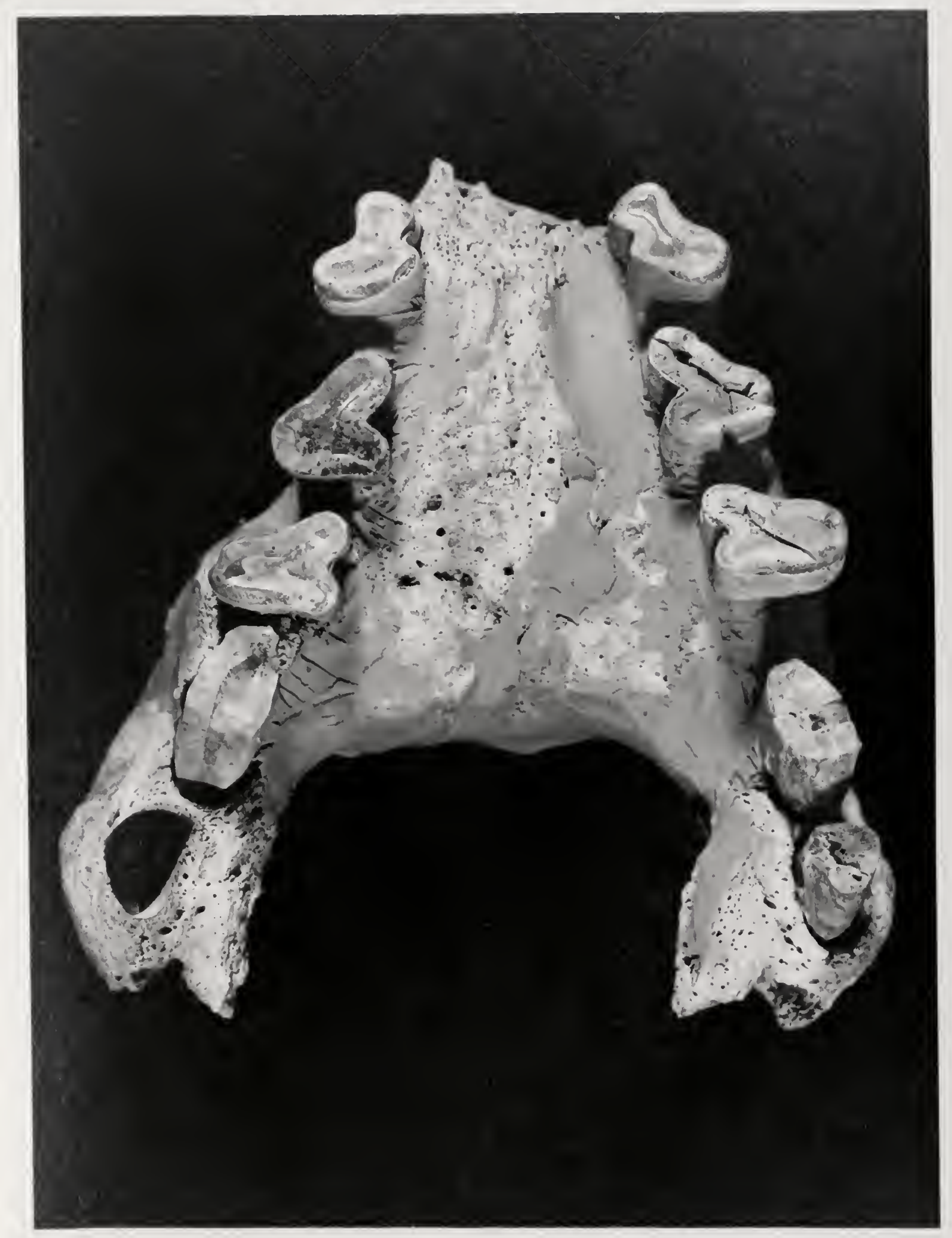


G. Mobustus obscrved, this tooth was worn ofe smoothly just above the alveolus. A very short diastema scparatcs the caniniform from the first molariform tooth in the ilaile m $_{\text {. }}$ specimal: .

Tle second upper molariform tooih of Jf 10922 is triangular in cross-sectjon, wjth the base of the triangle placed lingually. The anteroposierjor distance is less iran the transverse diameter in this species, while the oppositc is true in G. harlani. Of the two specinens of G. roburtus: for which measurements are provided, one agrees with $G$. chapadmalensis wile the other is nearly equal in bot? diameters. The third upper molariform tooth of Ur 1092\% is similar in shape to the second and agreos morphologice? Iy with tle corresponding teeth in both $\mathrm{G}$. harlani and $\mathrm{G}$. robistus. The fourth molariform tooth is relatively small compared to the Axgentine specimen of G. chapdamalensis although the shape is the same.

The matate is very much conetricted in the area of the last uppor teeth and very much expandeci at the anterjor ond of the maxilia. Both of these characters are more extreme in vJ: 10922 than in tre chapadmalalan spoaimon, or in specimens of $(-$ harlani and G. robustus.

Iower detition: The lorar caninjerm or UI 10922

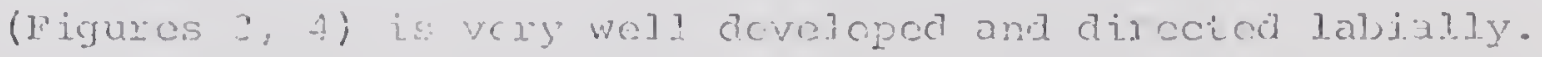


Figure 3

Glossotherium chapadmalensis Right Mandible, Lateral View X 0.82 (Iinear) 


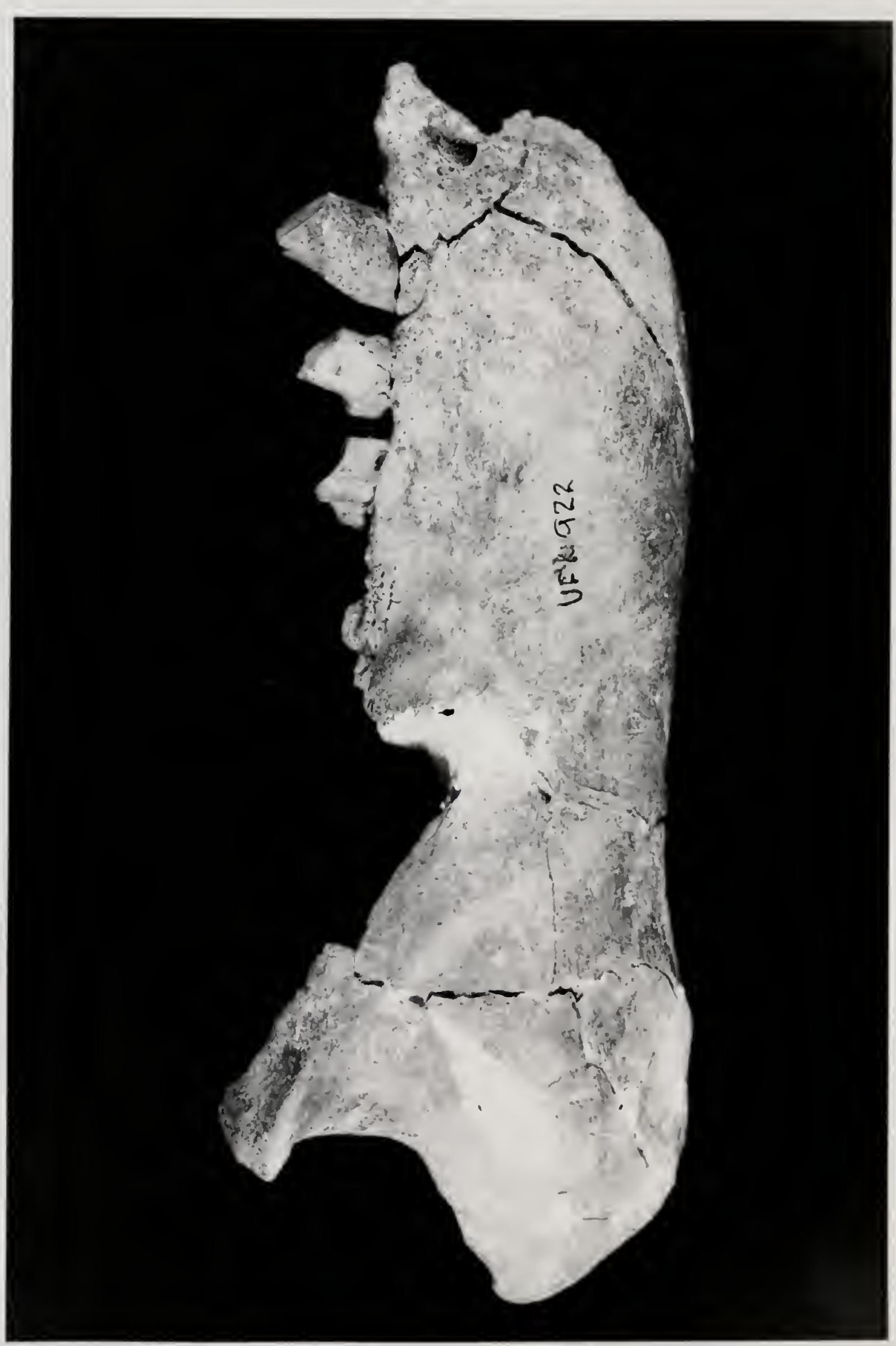


Figure 4

Glossotherium chapadmalensis Right Mandible, Occlusal Vici X 0.82 ( 1 inear) 


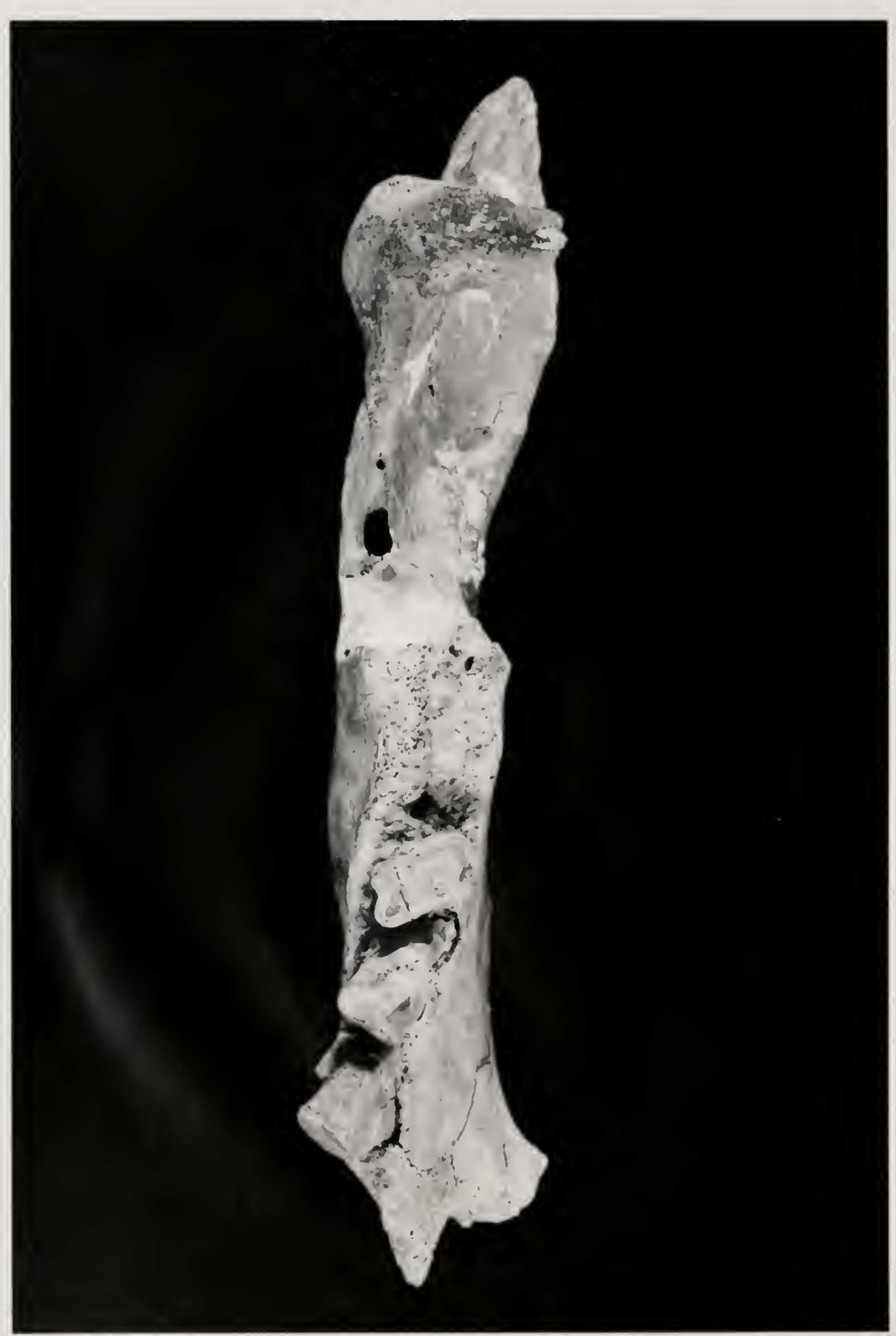


This tooti is relatively slightly larger than the curresponding tooth in the South Amexican specimen of G. chareubiensis. The tooth is pointed when vicwed laterally due to the dual occlusion with the ripper caniniform and the first molariform tooth.

The first lower molaxiform tooth is also redatively robust. It is somewhat triangular in cross-section and protrudes fairly high above the alveolus. Win tooth is also turned slightly to the outside and closely resembles the lower caniniform.

The second molariform tooth is rectangular and is turned lingually, so that its long axis does not parallel the tooth row. Stock (1925), in discussing this tooth, used the long axis as the arteroposterior length whi]e Kraglievich (1025) used the shorter axis of the tooth for this measurement. For comparison. Kraglievich's method of measuring is used here for the Haile XVA specileen and Stock's methoi for measuring G. robustus. It was necessary to reverse the measurements of $G$. robustus provided by Kraglievich (1928) so they would be consistent with the other material considered. Thus, the secmingly greai difference in the measurements of the second molariform teeth is actually an expression of the fact that the orientation of the teeth is different in ile species and does not indicate gross morphologica? jifferences tin the tenth. 
The thisd lower molariform tooth is of a slightly different shape in G. chapadmalensis. The two main colmms are scparated by a thin bridge, while in G. harlani and $\underline{G}$. robustus this briage is thicker.

Mandible: Unfortunately, the mandibujar symphysis is not preserved in the Haile XVA specimen. The portion of the mandible prescnt agrees in morphology with the other two species. Measurements of the upper and lower dentitions are presented in Table 3 .

Cranial matcrial: The remainder of the Haile XVI cranial material consists of part of the occipital bone and portions of the left and right periotic bones. The occipital fragment contains the left condyle and a portion of the otic region. The hypoglossal canal, jugular formen, and auditory meatus show no observable differences from those of G. harlani and G. robustus. A portion of the left suruamosal is attachcd to the occipital. Part of the right squamosal is present including the zygomatic process. Vortebrae: The atias of UF 10922 is well preserved. Accoraing to stock (1925) this element differs in G. harlani and G. robustus. The posterior portion of the laterai. process does not extend as far forward in G. harlani. The location of the dorsal foramina also varies: In G. harlani they alo glite fur ipart while in G. robustus they are 


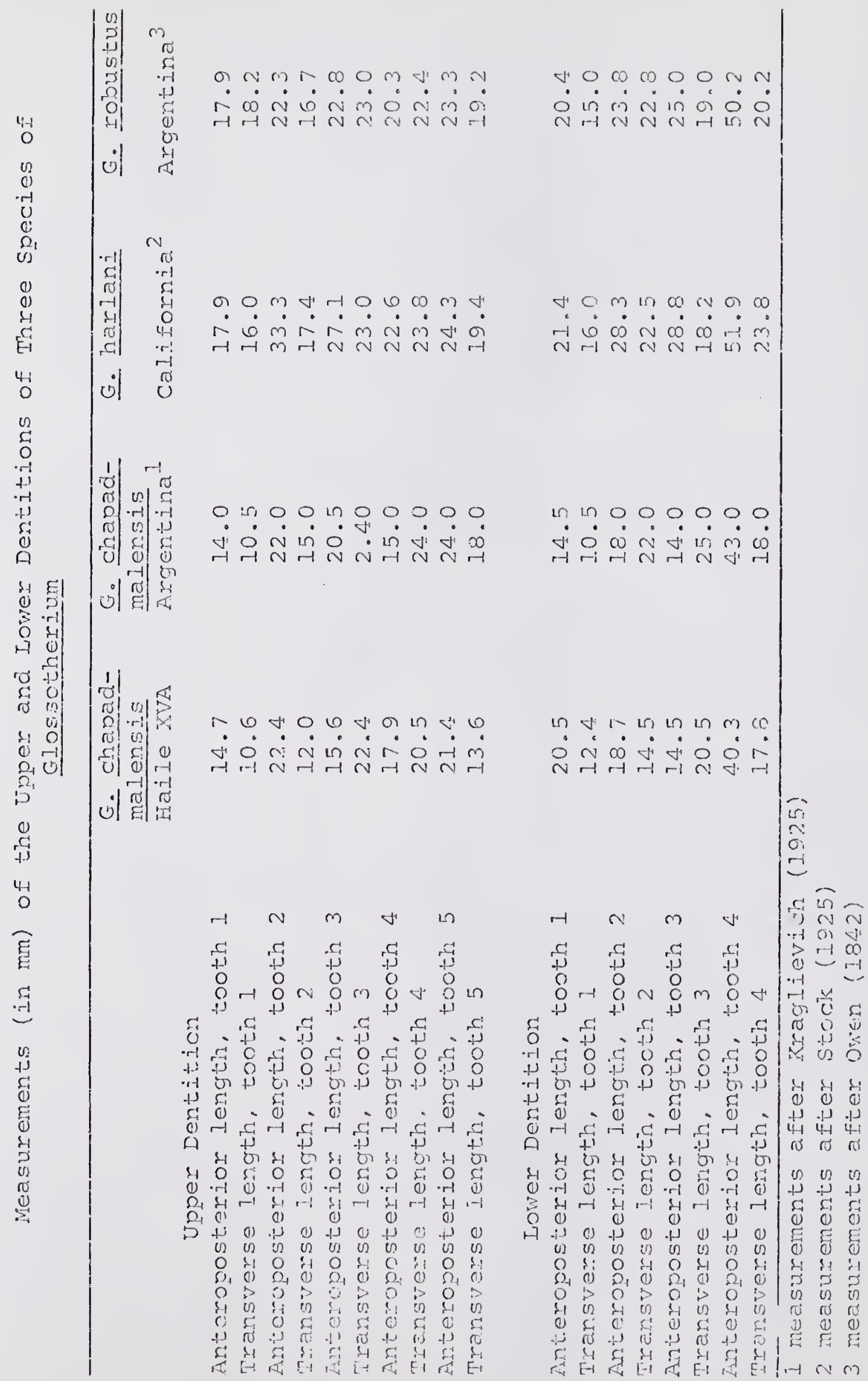


close togchex. Ur 1092? definitcly agrecs with G. harlini in the expression of these two characters.

The remainder of the vertebrac preserved are, for tho most part, ir poor condition, and as a jesult their posjtions in the vertebral column could not be actermined accurately.

Front Iimbs: Neither scapula of UF 1092\% is present. The right humerus is present. Neither radius is preserred, although both ulnae are present. The left ulna is so poorly preserved that: it could not be removed from the plastex: jackel in which it was collected.

Several bones of the manus are present in the Haile xi\% material. The cunejform appears to be somewlat differcnt in G. chapadmalensis than in G. harlani. This elemens in UF 10922, when viewed from the palmer aspect, is square in apparance as opposed to being rectangular in the figure of G. hariani provided by stock (1925, rigure 720). These differences are reflected by tine measurcments of this elcment in Table: 4. In UF 10922, tle pjoxima1-distal distance j.s greater than the distance acioss the winar articular surface while the opposite is truc for 39 specimens measured by stock. The cunciform atppears to be a derpes elcment in G. chapadmalensig than jis G. har whi. ghe remairder of the

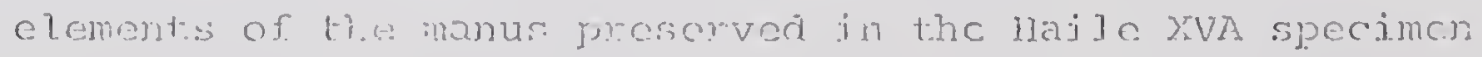


Table 1

Limb Measurements (in mm) of Glossotherium chapacmalensis and Glossotherium harlani.

Humerus

$$
\begin{aligned}
& \text { G. chapadmalemsis G. harlani } \\
& \text { UF 10922. Maile XVA Rancho La Brea } \\
& \text { left right }
\end{aligned}
$$

Greatest anteroposterior

distance of head

Greatest wiath of shaft

at deltoid ridge

width of distal articular surface

$$
\text { UInत }
$$

Greatest length

wiath of distal articular surface

\section{Femur}

Total length

Transverse diameter of head

Least width of shaft

Greatest wiath across distal tuberosities

width of distal

- condyles

wiath of intercondyloid space.

Width of inner condyle

Vertical exient of inner condyle

$$
\text { Tijia }
$$

Total length

Greatest width, proximal end

Greatest width, distal end

Anteroposterior distance, distal end

$$
\text { Fibula }
$$

Total length

width, proximal end

wiati distal end

*Afier stock (1925). The measurements represent the mean of iaxge samp?as. wito number of specimens varied from clenent to elument mol ju seme cises was not givon.

123.8

122.6

133.2

395.9

55.0

546.4

127.8

164.6

234.8

188.5

$27.1 \quad \ldots \ldots \quad 47$

$\begin{array}{lll}47.2 & 47.2 & 88.7\end{array}$

$\begin{array}{lll}67 & 69.8 & 120\end{array}$

$\begin{array}{lll}181 & 176 & 247.3\end{array}$

$114 \quad 185.2$

$\begin{array}{lll}90 & 88 & 142.5\end{array}$

$\begin{array}{lll}64.8 & 66.6 & 101.9\end{array}$

$183 \quad 263$

$50.5 \quad \ldots 103.6$

$39.5 \quad \cdots 3.5$ 
are the ]eft scaphoid, right pisiform, left metacarpal I11, and left phalanx II, digit TIT.

Ilind Jimus: The pelvis is missing in UE 10922. The left fomur is complote while the right is badly tragmented. Both tibiae, and the left fibula are well preservec.

Several clements of the pes are prescut. These axe the right calcancum, right astragalus, left and right metatarsal. III, left and right phalanx II, digit III, and an ungual phalānx, digit III.

A comparison of the limb elements of the Haile XVA specimen with those of G. harlani from various Rancholabrean deposits of Florida and with the figures of G. harlani provided by stock (1925) ind figures of G. robustus (Owen: 1842) shows, for the most part, no great morphological differences. Mll three of those species appear to be vory similar postcranially. Comparative measurements of Uf: 10922 and stock's (1925) Rancholalyean material show the Haile XVI material to be significantiy smaller (Tables 4,5 ). Glossotherium rolustus is larger, ahout the size of 6 . $\underline{\text { harlanj. }}$

Discussion: There has becn much confusion concerning the taxunomy of the gencra Mylodon and Glossotherium. Kragi.iovich (1928) his presentad a thorough revicw of the

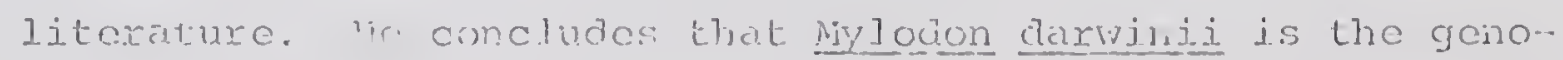




\section{Table 5}

Measurcments (in mm) of the Bones of the Manus and Pes of Glossotherium chapadmalensis From Haile XVA and Glossotherium harlani.

scaphoid

Greatest distance across articular surface cuneiform

Greatest distance across dorsal surface from inner side to outer

Greatest proximal-distal distance

Distance across articular. surface for ulna pisiform

Greatest length

Greatest depth

Greatest width Metacarpal III

Grcatest length

width, proximal end

Wiath, aistal. end

Depth, proximal end Phalanx II, digit III

Jength

Depth, inner conayle

vidtu, proximel end

calcaneum

Greatest width, anterior end

Greatest depth

Astrragalus

Arteroposterior diancter

Metatarsal IV

seagth

Width, proximal end

Depth, proximal. ena

widtin, aistal end

lepth, distal end G. chapadmalensis $\frac{\text { G. harlani* }}{\text { Jight }}$

46.2

$75.3(39) * *$

42.1

$68.5(42)$

34.3

50.5

31.2

$-\cdots$

E. 3

$\begin{array}{ll}\ldots \ldots & 25.3 \\ \cdots \ldots & 18.9 \\ \cdots- & 20.9\end{array}$

$55.6(22)$

36.4

34.7

71.7

51.9

$103.1 \quad(30)$

30.5

75.2

50.9

42.0

66.0

40.5

23.5

48.9 (4.2)

26.2

39.9

47.9

$\begin{array}{rrrr}\ldots \ldots & 57.4 & 91.8 & (21) \\ \ldots & 83.4 & 125.4 & \\ & & & \\ & 76.1 & 140.2 & (41) \\ 84.3 & \ldots \ldots & 119.3 & (29) \\ 41.2 & 41.5 & 60.7 & \\ 34.3 & 37.1 & 45.5 & \\ 38.5 & \ldots \ldots- & 50.1 & \\ 35.3 & \ldots \ldots- & 43.5 & \end{array}$


Table 5 (continued)

Phalanx II, digit III

Length

Depth, inner condyle

width, proximal end

Ungual phalaix, digit I.II

Iscngth

proximal-djstal distance of

$$
\text { ungual base }
$$

G. Chapadmalensis G. harlani*

width, proximal cnd

$\begin{array}{lll}30.2 & 31.0 & 35.4(32) \\ 20.4 & 21.5 & 21.8 \\ 22.6 & 22.5 & 35.1\end{array}$

104.4

174.1

:measurcments after stock (1925)
$\therefore$ number in parentheses refers to the sample size from which
the mean (the numbers in the right-hand colum) was
calculated 
type of Mylodon, and that what Owen (1840) described as Mylodon robustus more correctly belongs to a distinct genus, Glossotherium. However, Kraglievich retains Paramylodon (Brown, 1903) as a valid genus even though stock (1925) showed that the type of paramylodon merely represented a vari-ation of what was then called Mylodon harlani. Simpson (1945) argues that if the North and South American forms (latc Pleistocene) are not generically aistinct, then they all belong to the genus Glossotherium. This view is followed here. Hoffstetter (1952) retains paramylodon as a subgenus of Glossotherium, recognized by its tenacncy to lose the upper caniniform tooth, and because of their narrow muzzles and long sizulls.

The partial, associated skeleton from Haile XVA is clearly a meinber of the Subfamily Mylodontinae as indicateci by tre single astragalar facet for articulation with the. calcaneum. Pollowing the above system of classification, it is a member of the genus Glossotherium. This speciner so closcly resembles Eumylodon fGlossotheriuni) chavadmalen-sis thot it is herc ascribed to that species. Glossotherium chapadmalers.is is an early pleistocene ground sloth from the Chapadinalal fauna of Argontina and is here reported from North Anerica for the first time. It is a small species which apposos to be very closely related to both G. harlani 
and G. rolmslus, differing from these two forms in the nature of the anterior centition and in overall size. It agrees with these two species in the morphology of most of the postcranjal elements witl the possible exception of some of the bunes of the manus and pes.

As this species is known from the eâly plejstocenc of Argentina and Floxidà it is thus temporally, geographically, and morphologically, a plausible ancestor of both G. harlani and $\mathrm{G}$. rojustus.

Family Dasypodidac

Kraqlievichia paranensis new subspecies

Holotype: UF 10902, partial skeleton collected by P. E. Kinsey, S. D. Weub, R. R. Allcn, and J. S. Robertcoil in 1964.

Type Locality and Horizon: Haile XVA, RI7E, T95, S25, Alachua County, Florida, Flancan.

Sulsocific Diagnosis: A member of the species Kraglievicita paranensis on the basis of all major morphological characteristics. Differs from the only other subspecies, represcnted by the South American members of the specics, in that the fourth tooth is reniform rather than peg-like and is not turned lingually, hut is nearly parallel with the iontli row.

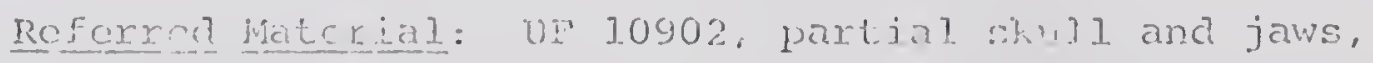


and associated skeleton, Haile XVA (holotype); Ur 17474, right ulna, also from Haile XVA; UF 10432, right hume:us, Sanie Fe I; UF 9354, right humerus, Santa Fe I; [T: 10449, lefi ulna, Santa Fe I; UF 10830, right radius, Sania fie I: Uj: 16371, left metatarsal IV, Waccasassa River; UP 27175 , rjght metatarsal IV, Santa Fe II; UF 17472., right metatarsal III, Santa pe II; UF 17476, right femir, Haile XIII; UF 17568, and U1: 17569, right naviculars, Haile XVA.

Description: The discovery of the Haile XVA skeleton, as well as isolated postcranial material from several other sites in Florida, affords an excelient opportunity to expand the description of this species. Heretofore, postcranial material of this speaies has been scarce.

ine followjing description is based for the most part on the Hailc XVA specimen. In some cases matorial from the other localitjes is used if corresponding elements are lacking in the Haile XVA material.

Comparisons are made with North American specimeris of Chiamytherium, as well as with descriptions and figures (particujarly Winge, 1915) of South Mmerican chlamytheres. Cranjun: The nasals (Figure 5b) of UF 10902 compare favoxauly in sime and morphology with the South American specimai: $c E K$. paranensis described by Casleilanos (1927). rhoy cirrer, hovever, in the prescnce of tiny protubcranecs 


\section{Figure 5}

Kraglivichia paranensis Cranial Materiai

A. Riglnt premaxillary

B. Nasal

c. Pallctal portion of maxiliavy

D. Zygomà, ventral view

E. Zygoma, laterial view

F. Right mandible, occlusal. view

G. Right mandible, lateral view

H. First lower tooth

I. Fourth lower tooth

Anbreviations: iof, inframplitil. foramern;

ju, jugal; nux, maxillaxy; mi-px, maxillaxy. premaxillary suture; uns: promillaty:

12, lasals; numbers refor to tooth siontonge. 

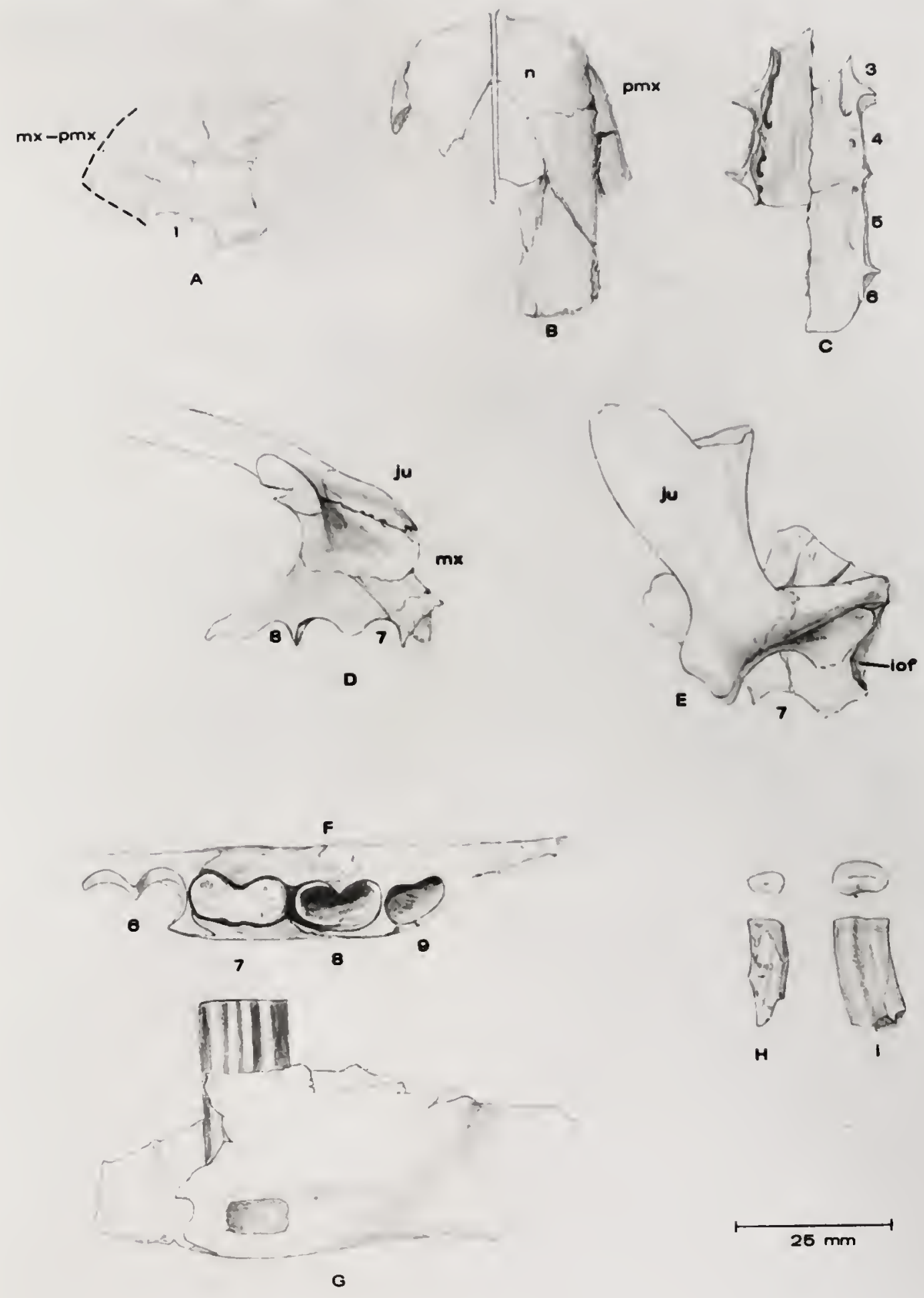
on the anterion crids of the nasals ucar the medial surficc. These structures are not preseni on any of the other chlamytherium or Kraglievichia specimens or figures studied. Only the anterior halves of the nasals are present in Un 10902, as the skuil had been exoded away, and only parts of it: were recovered.

The premaxillary (Figure 5a) contains only one alvoolus. The premaxillary-maxillary suture forms the posterici border of the first alveolus, as is the case in chlamytherium. In Holmesina (=Chlamytherjum), one of the dj.stinguishing features was supposediy the presence of one tooth in the premaxillary. Two teeth were supposcaly present in the premaxillary of Chlarnytherium. "The neotype of "Iolmesing" (AMNI 26856, Simpson, 1930) as well as UF 889 (C. Eeptonirionalis from Iornsby Springs, Bader, 1957) illustrates this conation. James (1957) states that in his specjmen of C. scpteririonalis (H.C.R. 4) there appears to be a suture both herore and after thu second tooth. A Chlamytherium skiull collected in South America by Dr. Gordon Edmund, Royal Ontario Muscum, has only one tooth in the premaxillary (limunce, pessonal communication). Thus, evon if this character slicula be found in some skull. not now linown, it would not scric to sejarate the Nolth and South American forms. 
The major foatures of the maxillary compare favorabiy with those in Chlanytherium. the infraorbital foramen (Figure 5e) is Iocated airectly above the sixth tooth in both genera. The anterior palatal foramina (Pigure 5u) are located between the posterior edges of the fourth teeth in the uaile xVE specimen, while their position is somewhat variable in chlanytherium. The maxillary process of the zygomatic arch is directly above the serenth tooth in both genera.

Only a portion of the zygomatic arch is present in Uf: 10902 (pigure 5d, e). The zygomatic process of the maxil-lary turns posteriorly and downward as it leaves the skul. The anterior portion of tle jugal, which borders the zygomatic process laterally, then turns upward and expands posteriorly to accept the aquamosal process. I welldeveloped suture present at the posterior end of the jugai indicates that in Kraglievichia, as in Chlamytherium, the zygomatic arch is complete. The base of tre zygomatic process of the maxillary is cxpanded by sinuses, as in Chlamytherium.

Upper dentjtion: There are nine upper and nine lower teeth in each jaw of Kraglicvichia. one upper tooth is located in the premaxillaxy. Because the incisors of most mamals ocur in the promaxillary, it is temptirg to refer 
to the rirst tooth in Kragljevicl!ia as an incisor. IIowever, the terminology "tnoth one" through "tooth nine" is coninnued in this report.

A conspicuous difrerence hetween the Haile XVA specimen and previously described specimens of Kraglievichia and Chlamytherium is secn in the nature of the anterior upper. dentition. In tine South American specimens of Kraglievichia, the first four tecth are oval in cross-section rather than renifoxm and have their long axes turned lingualiy. In Chlamyiherium, the first three teeth show this condition, yul the fourth is usually bilobate and parallel with the rest of the tooth row. This character is considered to be inportant in the evolution of the chlamytheres (castellanos, 3937; Simpson, 1930). It is obvious, however, that tisis trait is variable. In James' (1957) specimen the first Enur teeth are oval, but the fourth tooth is parallol with the rest of the tooth row, rather than being canted lingually. The peg-like nature of the fourth tocth may represent a pintivis condition, assuming rraglicvichia is the ancestor of chlamythexim. Vassallia, another even nore primitive chlanythere, with its first five teeth being peg-like and canted lingually, also shows tilis evolutiondiy trend. Costchlanos (19.37) secs the aro?ution of chlamythere tecth proigressing from the hack of ho tooth row io the front, 
with the teeth tonding to become bilobate and the tooth rows becoming parallel. The Haile XVA specimen appears to be intermeaiate between Iragljevichia and Chlamytherium in this character. The fourth alveolus shows that this tooth was noderately bilobate and nearly parallel with the posterior teeth. That this could represent individual variation should not be overlooked, especially when one considers the Iimited number of Kraglievichia specimens known; but when all the chlamythere specimens known are cor... sidered, the trend toward bilobate and parallel toeth seems evident. Cranial and upper dentition measurements are providea in Table 5.

Mandilole and lower dentition: Partjal left anc right mandibles are preserved in UF 10902. In the right mardibie (Figures 5f, g) the seventh tooth is complete while the eighth is broken off below the level of the alveolus. Alveoli for the sixth and ninth teeth are present. The fragmentary nature of the two jaws makes them difficult to compare in detail. The major aifferences between the mandibles of Iraglievichia and ChIamytherium, accoraing to previous worters, are in the shape and orientation of the arterior teeth. Unfortunately, this portion is lacking in both manaibles of UF 10902. wherc appear to be ro differ. cuces in ije poterior portion of the randibles excopt for 


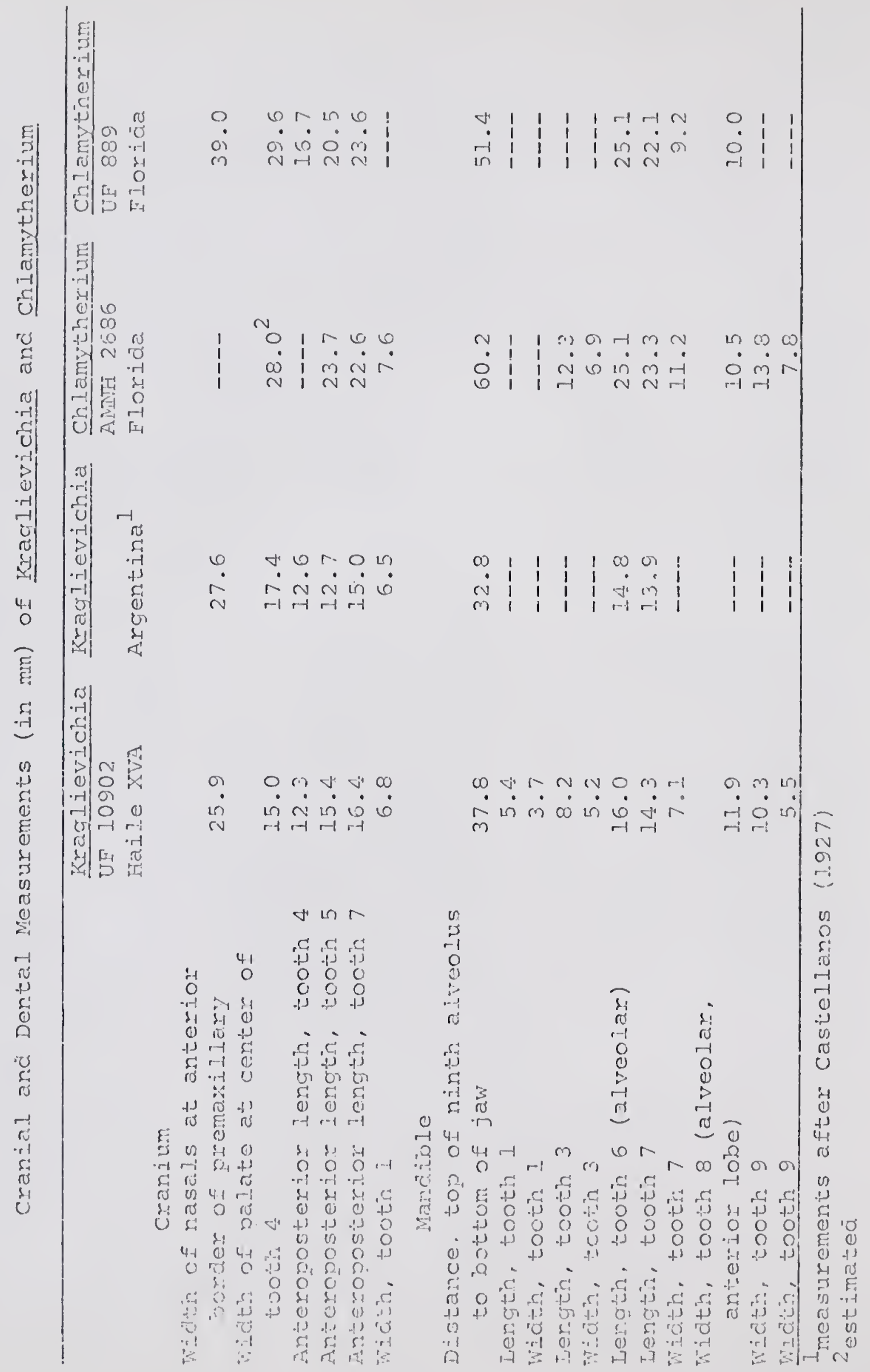


size. Measmements ot the lower dentition ase provided in Table 6.

Vertebrac: The vertebral material from the Haile XVh sliejeton consists of seven thoracic, five lumbar, and four. caudal vertebrac. Five of the thoracic veriehrae are cemented together in the proper sequence by a cuarse, large grained sandstone. Comparisons of these specimens with the vertebrae of an excellent chlamylherium skeleton from Branford IA, Suwannee County (Rancholabrean), show no significant morphological differences except for size.

Front limbs: In discussion of the major limb elements, a comparison is also made with Dasyrus. Kragievichia is approximately the same size as Rancluolabrean specimens of Dasypus bellus, a large extinct pleistocene armadillo. Conceivably, limb bones of the two could be confused. The right humerus of Ut 10902 is well preserved except for the idstal. end (Figure 6a, b). The humerus of Kraglievichia is greatly expanded lateraliy (as seen in the specinens from Santa FC I), The supracondylar foramen is relatively larger than in Dasypus. The articular surface for the radjus is concave in Krälievichia, whercas it hais a slight converity in Dasypus. The supinator ricige is relatively narrower in Kraglievinhia, and the deltoid riage is wilier. phe proximal end of the hmerus is similar in the 


\section{Figure 6}

Kragljevichia paranensis Front Limb Elements

A. Right humerus, mecial view

B. Right humerus, anterior view

c. Left ulna, medial view

D. Left ulna, anterior viev

k. Left radius, posterior vicw

F. Left racius, anterior view

$\mathrm{X} 0.60$ (linear) 


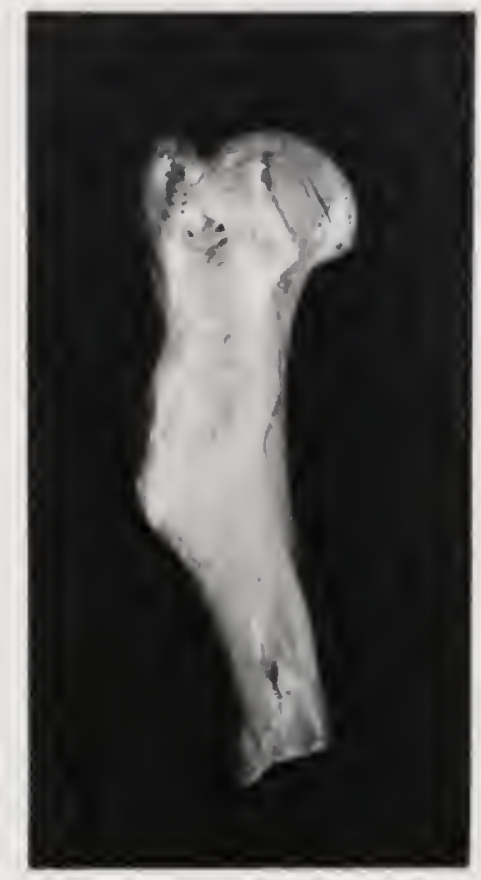

A
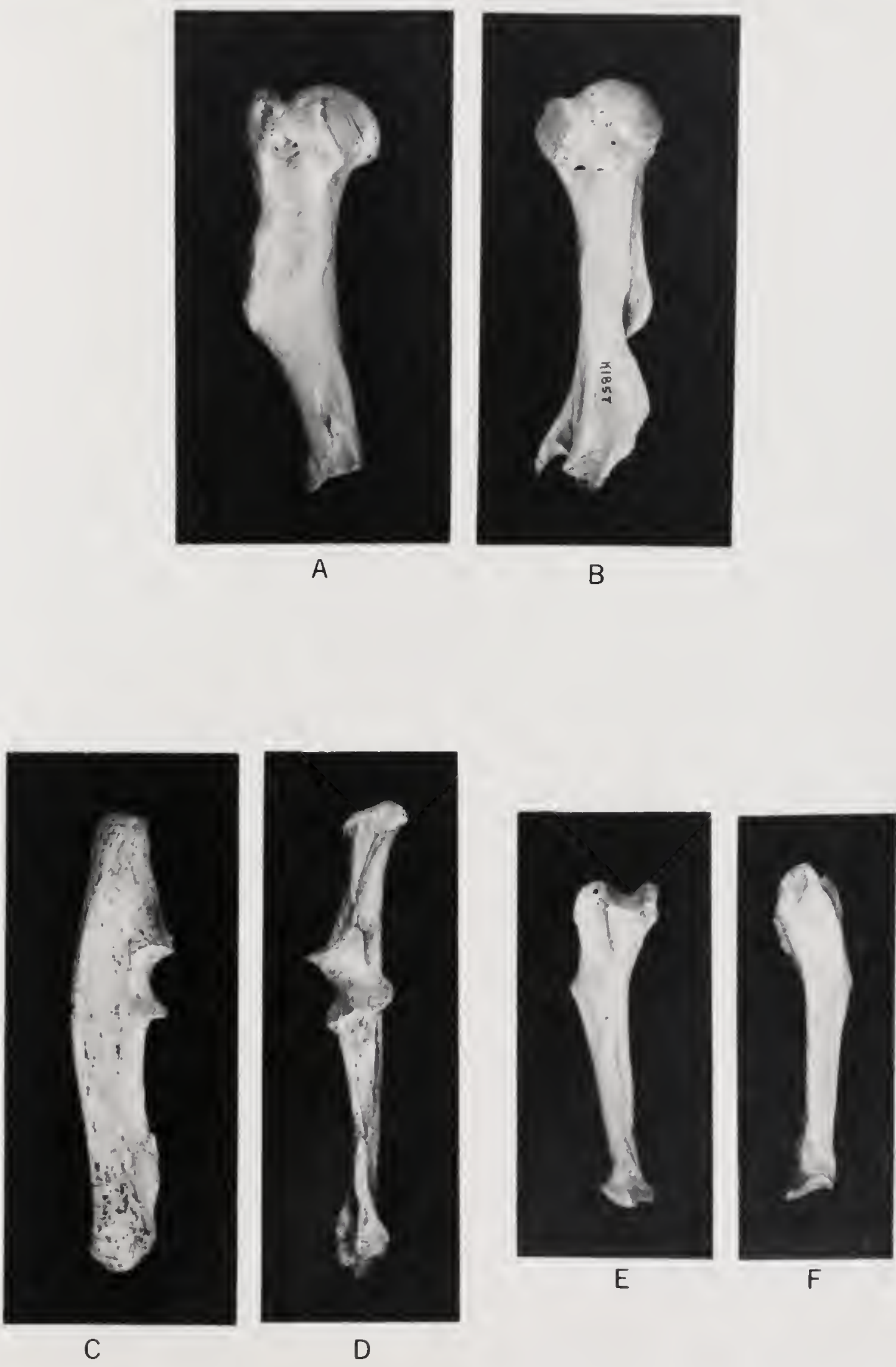

C

D 
two gencra. Comprison between Kraglievichia and Chlamy= thes:um shows no distinct differences in this element excepi for size.

Therc are three unae from the Haile XVA sj.te. n'wo of these specimens appeax to be from the same individual as they are similarly preserved, are of opposite sides, and agree very closcly in measuroments (Iabie 7). Tlie ulna of Kraglievichia (Figure $6 c, d$ ) is laterally flattened and possesses a long olecranon process. The articular faccts for the radius and medial condyle of the humejus are a single structure in this form, while in Dasyous they are partially divided. Another striking difference is a lateral groove which runs the entire length of the ulna in Dasypu:s, but which terminates at the upper border of the semilunar notch in Kraglievichia. Size appears to be the only difference between the unae of Kraglierichia and Chlamytheriuri.

As in Dasyous, the distal end of the radius is massive compared io the proximal end although it is less flattened in Kraglievichia (Figure 6e, r). The proximal portion of the shafe is rolatively thicker and hess curved in Kragli.evichia. Comparison with chlamytherium shows only a size aifference.

The Jeft mescarpal It is prescrved with the Haile XVA

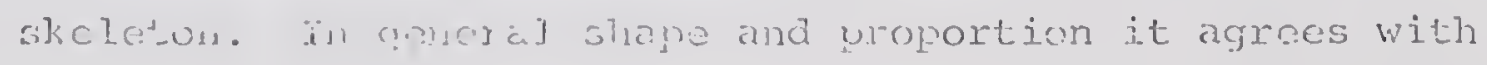


Measurcments (in mm) of I,imb Elenent: of Kraglievichia paranensis. UI 10902, ITaije XVA

\section{ITumerus}

laceral width, proximal cid

Anteroposterior width, proximal end

Greatest anteroposteriur diameter of shart

Jateral widit oi shaft at same location

Distance from proximal enci to top of

entepiconaylar foramen

Left Right

Ulna

Total length

Lateral width, proximal end

Lateral width, distal end

Lateral width at semilunai notch

Anteroposterior width at semilunar notch

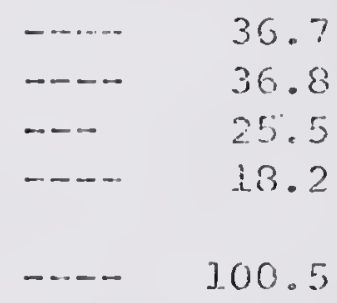

Radius

'Iotal length

Lateral. width, proximal end

Anteroposterior widtin, proximal end

Lateral wjath, aistal end

Anteroposterior width, distal end

$\begin{array}{rr}129.0 & \ldots- \\ 17.2 & -\cdots- \\ 16.1 & -\cdots . \\ 25.5 & 25.7 \\ 29.4 & 30.5\end{array}$

Metacarpal IT

Total length

Width, proximal end

32.8

Depth, proximal end

10.9

1.4. 5

Width, distal end

Depth, distal end

$\begin{array}{ll}89.2 & 8 \% .2 \\ 22.6 & ? 2.3 \\ 11.7 & 7.7 .1 \\ 23.0 & 22.3 \\ 17.4 & 76.5\end{array}$

Metacarpal III

Total length

wiath, proximal end

10.5

11.2

Depti, proximal end

width, distal end

Depth, distal end

$\begin{array}{ll}34.4 & 36.3 \\ 13.8 & 14.5 \\ 12.8 & 13.0 \\ 12.6 & 13.4 \\ 10.5 & 11.0\end{array}$

UnguaI Thalanx, Digit V

Total Iength

widtin, proximal end Jepth, ploximal end 


\section{Pemux}

l'otal length

Lateral wiath, proximal end

Anteroposterior thicknoss of yreater

trochanter

Iateral width of shaft at third trochanter

Anteroposterior thickness of shart at same point

Greatcst lateral wiath of articular facets

Greatest anteroposterior width, distal end

Tibia and Fibula

Total length

Lateral width, distal end

Anteropostexior width, distal end

Calcaneum

Total length

wictin of articular facets for astragalus

Depth of racet for cuboja

width of facet: for cuboid

Navicular

Greatest lateral width

Greatest anteroposterior distance

Greatest depth

\section{Metatarsal II}

Total lengih

Width, proximal end

Depth, proxjnitl end

Width, djstai end (articular surface)

Depth, cistal cnd (articulir surface)

\section{Metatarsal JII}

Total length

widith, proximal end

Denth, proximal end

width, distal cnd (articular surface)

jepth, distal ond (articular surface)
Left Right

$\begin{array}{rr}\ldots & 193.5 \\ \ldots \ldots & 60.9 \\ \ldots \ldots & 41.7 \\ \ldots & 41.3 \\ \ldots- & 23.7 \\ \ldots \ldots & 48.4 \\ \ldots & 51.5\end{array}$

$\begin{array}{rr}\ldots & 121.0 \\ \ldots \ldots & 46.7 \\ \ldots- & 25.1\end{array}$

-.. 63.3

-... 280

-.- 12.2

-.. J1.5

… $\quad 39.5$

23.3

22.5

33. 32.8

$12.2 \quad 1.2 .5$

$13.8 \quad 1.1 .3$

$13 . ? \quad 13.7$

$11.3 \quad 10.2$

$36.5 \quad 34.5$

$15.0 \quad 14.9$

14.7 1.4.4

13.2 i2. 3

1.1. $3 \quad 11.5$

\section{Ungुนal Pla Ian\%, Digit V}

jotal i enst? 
the same element of chlamytherium. The facet for articulation with the trapezoid, however, is quite different. When viewed laterally, this facet is a smooth curve in Chlamytherium, while in Kraglievichia it forms a sharp, V-shaped indention. The facet for articulation with the magnum $\dot{t}$ s oblong in Chlamytherium, while it is round in Kraglievichial. The facet for articulation with the trapezoid is wider dorsal.ly in Chlamytherium. This extra width gives the facet for metacarpal III a different shape. In Chlamytherium it bulges out proximally to form a quarter diameter for the facet whici articulates with the trapezoid. It appears that less of the trapezoid articulates with metacarpal III in Kraglievichia.

Left and right metacarpals III are preserved in UF 10902. In this element the facet for articulation wjth metacärpas. II and the trapezoid shows a relatively greater association with the trapezoid than with the adjacent metacarpal. The facet for the magnum in both Chlanytherium and Kraglievichia is convex dorsally and concave ventrally. In Kraglievichia the greater portion of the facet is corves, while the opposite is true in chlamytherium. The ventral portion of this facet, when viewed from the ventral aspect, is parallel in a line at righi angles to the long axis of the bone in Chlamytherium whilo in kraglievichia it is oblique.

Hing limbs: The fernus (Fiçure 7o, b) and the tibia and 
Figure 7

Kraglicviclia paranensis Hind Jimb Elemenis

A. Right fomur, anterior view

B. Right femur, lateral view

C. Right tibia and fibula, anterior view

D. Right tibia and fibula, laceral view

X 0.60 (Iinear) 

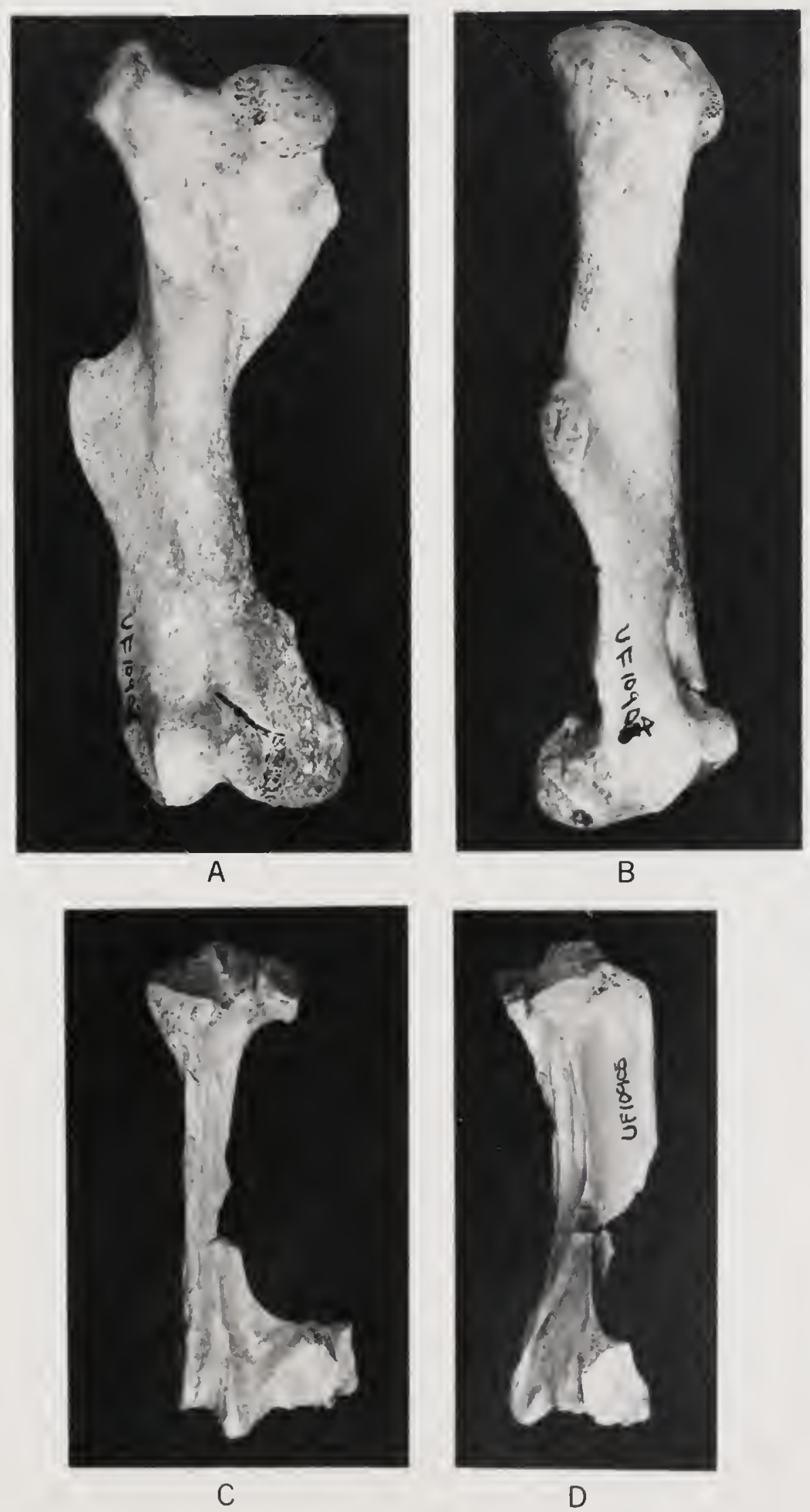
fibula (Eigure 7i. d) show no morplologicaj differcices fiom those of Chlcmythexium creept for sizc.

The calcaneum of liaglicuichia is relatively less ex-pandea at tire distal end, and is a relitively less robust. element than that of Chiamytherjum (Figure 8). The facets for articulation wit? tie astragalus are quite aifferent. In Kraglievichia the facets are connected, forming a double facet, whilc in Chlamytherium they are separated by a central valley. The relative proportions of the two facets also differ. In Chlamytherium, the lateral facet is much larger than the medial facet, while in Kraglievichia they are nore nearly the sane size.

The navicular of Kraglievichia shows no appreciable differences from that of Chlamytherium. A comparison of. the three right naviculars from Haile XVA with one another sin: only a slight variation in the relative shapes and sizes of the facets for articulation with the cunciforms.

Regaiding the metatarsal. II, the facet for articulation With the mesocuncifoim is relatively nexrower ventrally in Kraglicyichia than in Chlamytherium. In Chlamytherium the medial. border cf metatarisal II forms an unkroken ?ine, while in reasijevichia these is an indentaijor at the proximal onc to accept the pioximat. chri of metatarsal I. Therc must

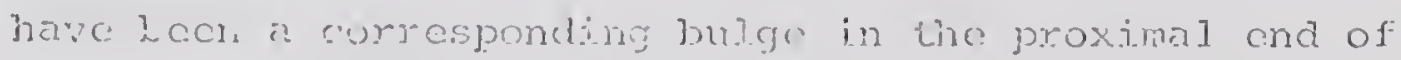


Figure 8

Kraglievichia and Chlamyherium Calcanea

I. Kuaglievichia paraiensis xight calcàneum, Hajle XV

B. ?Kraglievichia sp. right calcanem, Inglis IA

C. Chlamytherium septentrionalis right calcaneum, Branfora IA

All appros. natural size 

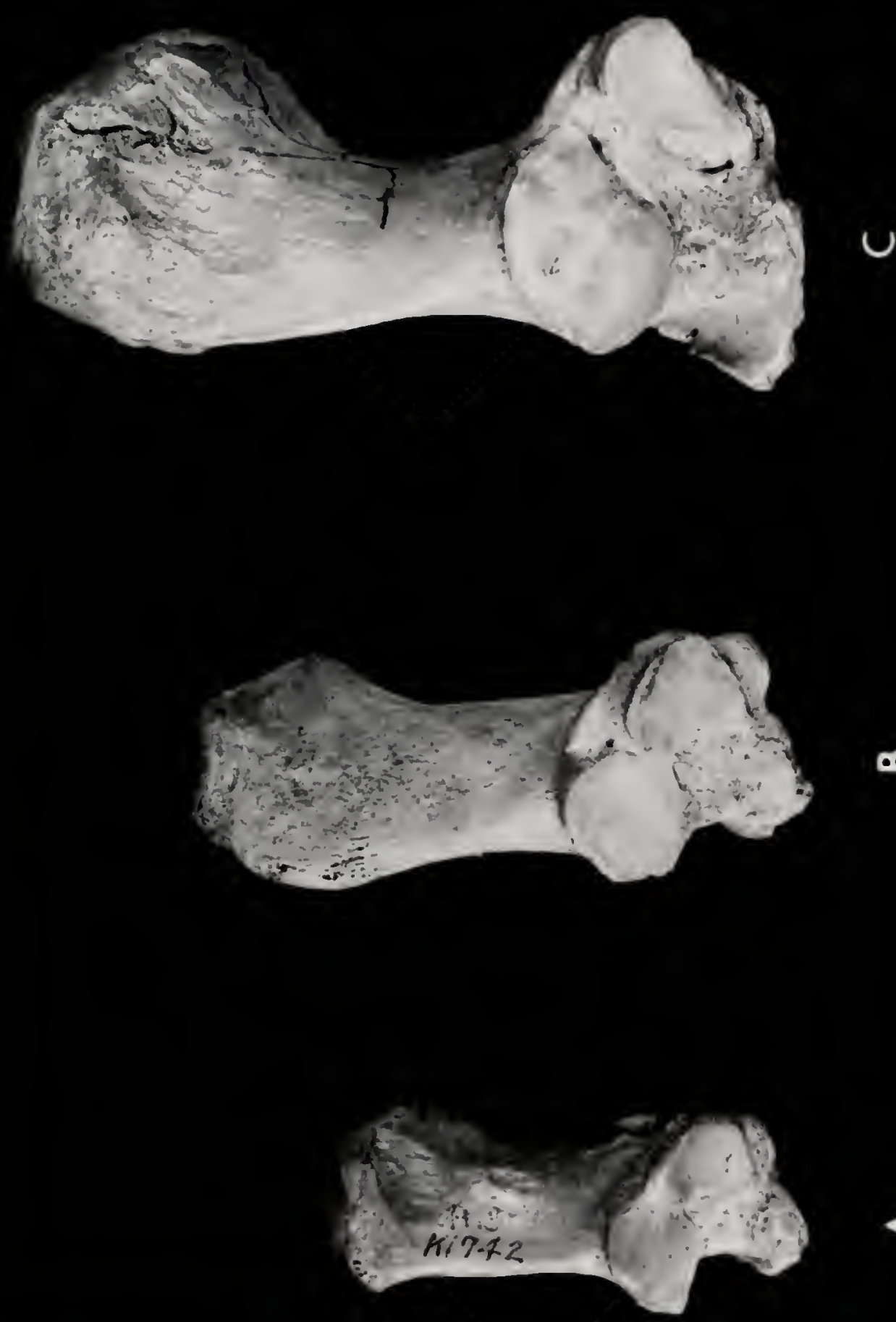
metatarsal I of Kraglievichia; no such feature occurs in metatarsal I of Chlamytherium.

Whel viewed laterally, the proximal alticular surface of metatarsal III appears rounded in Kraglievichia while in Chlamytherium it forms a straight line, perpendicular to the long axis of the element. Due to the rounding of the proximal end of this element in Fraglievichia, the articular surface can be seen when the element is viewed from above; this is not the sase for Chlamytherium. This would appear to permit more dorsoventral movement of the toes of $\mathrm{Krag}$ Iievichia.

Regarding metatarsal IV, the facets for articliation with metatarsal III and the cuboid are a single structure in Kraqlievichia, while they are two separate structures in

\section{Chlamytherium.}

Two ungual phalanges of UF 10902, both from aigit $V$, have been recoverea from Haile XVA. One is ratheir nartow and pointed, and the other is blunt and broad. Apparanty the ungual phatanges of the front feet were pointed, while those of the hind feet were olunt. The same is true in Chlamytherium. Measuremonts of limb elemerts of other examples of Kraglievichia from various florida localities are presented in rabie 8. 
Talbje 8

Moasurements (in nunj of Jimb Elements of Kragljevichia paranensis From Various torida Jocalities

UF 10432 (right) UF 9354 (right)
Santa FC I
Santa Fe I

Grcatest anteroposterior

diameter of shaft

Lateral. wicth of shaft at

same point

Latelal width, distal cna

Greatest wiath of distal

articular surface

28.8

19.5

$60.2 \quad 54.2$

Ulnä

37.8

36.3

Total length Sante Fe I

116.5

1.7.6

10.4

Lateral width, distai end

Lateral width at semilunar notch

20.5

25.1

Anteroposterior width at

scrilunar notch

23.4

31.8

Radius

Total length

'I'ransverse width, proximal end

Anteropostcrior width, proximal end

Transverse width, dista]. end

Anteroposterior width, distal end

Femu1

UF 10830 (richt)

Sante Fe I.

105.2

24.5

13.3

23.1

20.6

rateral wilith, proximal end

Anterojosterior width, proximal end

Jateral widih of shaft at third trochanter

Anteroposterior wjoth of shait at same point

CaI cancum

UF 17476 (ieft)

Hai.le XII B

55.3

34.2

38.8

16.5

UF 17473 (Ieft)

Santa $\mathrm{Fe} I \mathrm{I}$

64.1

24.5

14.9

10.6 
Table 8 (continued)

\section{Navicular}

Greatest lateral wiath

Greatest anteroposterior

distance

Greatest depth

Metatarsal II

Total length

Width, proximal end

Deptin, proximal end

width, distal end (articular surface)

Depth, distal enà (articular surface)

\section{Wetatarsal III}

Total length

Width, proximal end

Depth, proximal end

Width, distal end (articular surface)

Depth, distal end (articular surface)

Nietatarsal IV

Total Iength

Width, proximal end

Depth, proximal end

width, dista]. end (articular surface)

Depth; distal end (articular surface)
UE 17569 (right)

Haile XVA

33.6

18.3

2.6 .6

UE

(1eft)

Haile XV

30.8

11.3

13.6

12. 3

10.2

UF 17472 (right)

Santa Fe IT

$$
\begin{aligned}
& 34.2 \\
& 1.6 .5 \\
& 15.2 \\
& 13.5 \\
& 11.4
\end{aligned}
$$

UF 17475 (richi)

Santa $F \in I I$.

29.5

11.2

12.2

15.1

10.5 
Revicw of the chlanytherijnae

Since the genus Kraglievichia is reported here for the first time in North America, this secms to be an appiopriate place for a review of this group on both continents. The nomenclatural history of the various chlamythese genera will first be discussed in the order of their introduction into the liferature. This will be followed by a bricf review of cach genus, in geological order, begjuning wi.th the oj.dest form.

The rirst remains of a cliamytherc were discovercd in a Brazilian cave deposit in 1836 by peter wilhelm wund and clescribed by him as Chlamytherium humboldtii (Lund, 1838). In his early works Lund referyed to this genus as chlemy.-. therium, but later (beginning in about 1840) ne began to call the genus Clllamydotherium without giving any reesul (Castellanos, 1927). Later authors used the name Chlamydotherium, apparent]y not realizing that this name, in the meantime, nad been given to a ganus of glyptodonts by Brann (I333). In 1875 Imeghino proposeo the name pampatherium for this genus, recognizing that the name chlamydotherium was occupied by the glyptodont genus. If later abandoned tinis bume liher he realined that sund had previously named the gonus chlanybherium. Faula couto (i956) has argued that Famatiogrum is a valid nume, as lund mont to call it

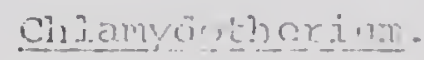


whe first North Anerican record of Chlamytherium was reported by Leidy (1839a) when he designated the species Glyptodon septentrionale. In the same year Ieidy, in another work (1889b), referred these specimens to the south American species ㄷ. humboldtii. Sellards (19.5) belierod that the North and South American forms represented different species and revived Leidy's original trivial name septentrionale.

In 1902 Ameghino described Machlydotherium from the Eocene of Patagonia.

Castellanos (1927) named two new genera of chiamytheres: Vassallial, based on an edentulous manaible and sevecal derinal plates; and Kraglievichia, based upon two skuils, a mandible. ana a small amount of postcranial nateriai. The genocypio species of Vassallia was originally Chlamycherium minutum (Moreno and Mercerat, 1891). Iraglievichia was erected to include C. paranensis, C. intermedia (Ameghino, 1887), and C. sul intermedius (Rovereto, 1914). The trivial lane paranensis was retained.

Simpson (1930) estahlished the genus Ilolmesina while scudying excellent inatorial of septentriora.is from the Seminole field in rostern peninsular Floxida. Subsequent authors have tonded to refar to the North ismerican forms as Holmesina ard th the south Tuncrican forlas as chlanvtherium. 
CastejJanos later (1.937) named plaina, bascd upon the type of c. intermedius which he har earlier placed in Kraglievichia. 'rhe reason for the establishment of this new genus was his interpretation of the lincage of the chlanytheres. He believed that there should be a form intermediate in size betrecn Kraglievichia anc Chlamytherium. Since C. intermedilis is larger than the other material referred to Kraglievicinia, he saw it as representing this intermediate form.

The genus Hoffstetteria of Castellanos (1957) was basen upon a skull collented in Ecuador. This skull had previousily been describei as C. occidentalis by Hoffstetter (1952).

Each of the chlamythere genera will now be briefly reviewed in geologic order keginning with the oldest, Machly... dotherium. This form is known from the Eocene of patagonia ara its relationship to the later chlamythejes is not known (simpson, 1945;. Chlamytheres are not know frcm the oligocene.

Voissclia precelas Kic:glievichia temporajly as it is known from the lü Venta funta of Niocene age in Colombia. The duthor has cxamined a skull from this locality (U.C.M.P. 40401; wich definitely represents Vassallia. This identi-fication is bas ud upor its small size, and the natuse of the anterjor ionijtico, in which tho first five tecth are peq- 
like and rolatca lingually. Vassillia has also been reported fxom Auracanean Reposits (Castellanos, 1946) so it appears that this genus did range into the pliocene.

Porta (1962) has reported Kraglievichia from tho Ia Vonta fauna in colombia, but this record was basea only mpor dermai plates which could just as well represent Vassallia. Other Miocene records of Kraglievichia have been reported as some previous works considcred this to be the age of the Auracanean deposjts; however, more recent interpretations of South Americai stratigraphy (patterson and Pasqual, .1968) demonstrate the furacanean to be Pliocene rathor than Miocene. Therefore, it appears that Ireglievicinia was restricted to the pliocene in South America. Castellanos (1927) has reported morphological aiffer.ences between Vassallia and Kraglievichia. In Vassallia the first five teeth tend to be peg-like and rotated linqually while only the first four teeth of Iraglievichia show this concition. Just how variable this characteristic is cannot be ascertained presently because of the lact: of comparative matorial knom for these genera. Vassallia is also significanty smailer than Kraglievichia. J.t is suspect.ed heie (as castollaros has suggested) that Vassallia is the anceston of krarlinevichia. 
dermal plates, Castejlanos (1927) was probajly comract in lis first juagment when he placed this material in the gonus Kaglicuichia. He considcred these plates to be intermediate in size and sculpluring beiween Kraglievichia and Chlamytherium. They seem, however, to fall within the size range expectea for the older armadillo genis. Furthermore: it seens quite difficult to interpret slight variation in plate rugosity as being generically sigrificant. It is therefore proposed here that plaina is a syronym of kraqIievichial.

The gomus Hoffstetteria (Castellanos, 1957) is base3 upon supposed differences in the shape and measurements of the tecth. The deviations, however, are clearly attributable to irdividual varintion. Hoffstetteria is here corsidered to be a synonym of Chlanytierium.

In Simpson's (1930) Acscription of Iolonesina, he listed a number of characters in which this new genus differea from Clilamytherium. However, Janies (1957) lics shown that the clidracters pointed out by simpson are not sufficient to separate the North and South Amejican forms generically, and that Holmesina is a synonym of Chlamytherimm. This report strengthers James' viows un this issue. Simpson (1930) has also argucd that if Holmesina is noi valia, then all the

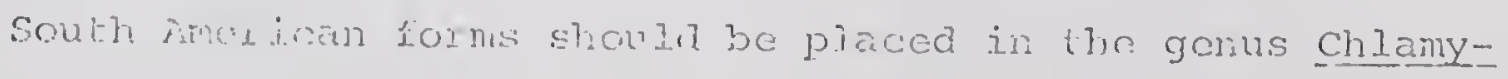


thexium as they are no more different from cach other than Chlamythorium is from Ilolmesind. There may be some justification for doing just this. In this report, however, new characters of Kraglievichia, different from Chlamytherium, have been pointed out whici, tovether with what previous workers have considered generic characters, justify retaining Kraglievichia às a valid genus.

The genera of chlamytheres, then, recognized in this report are Machlydotherium (Eocene), Vassallja (Miocens and Piiocene, South America), Kraglievichia (Pliocene, South America and early Pleistocene, North America), and ChIamytherium (Pleistocene, North and South America).

Evolution of the chlamytheres Tha principle morphological trend in chlamythere evolution since the Miocene was an jucrease in size. Vassaliia was the smallest form in the finorm chlanythere lineage, followed by Kraglievichia which was slightly larger. An examination of the two femora in Figure 9 shows the great size difference between Kraglievichia and chlamytherium. The intemediace steps in this size increase are illustrated in Figure 10, which shows dermal plates from deposits represeniting various stages of the pleistocene. The Blancan Haile XVA plates are the smallest, followed by those from the Irvingtonian Inglis Tf site. Sightly larger still are the plates from 
Figure 9

Kraglievichia and Chlamytheriun Femora

A. Chlamytherium septentricnalis right femis Branford IA

B. kraglicvichie paranonsis right femur, Haile XVA

$\mathrm{X} 0.60$ (Jinear) 

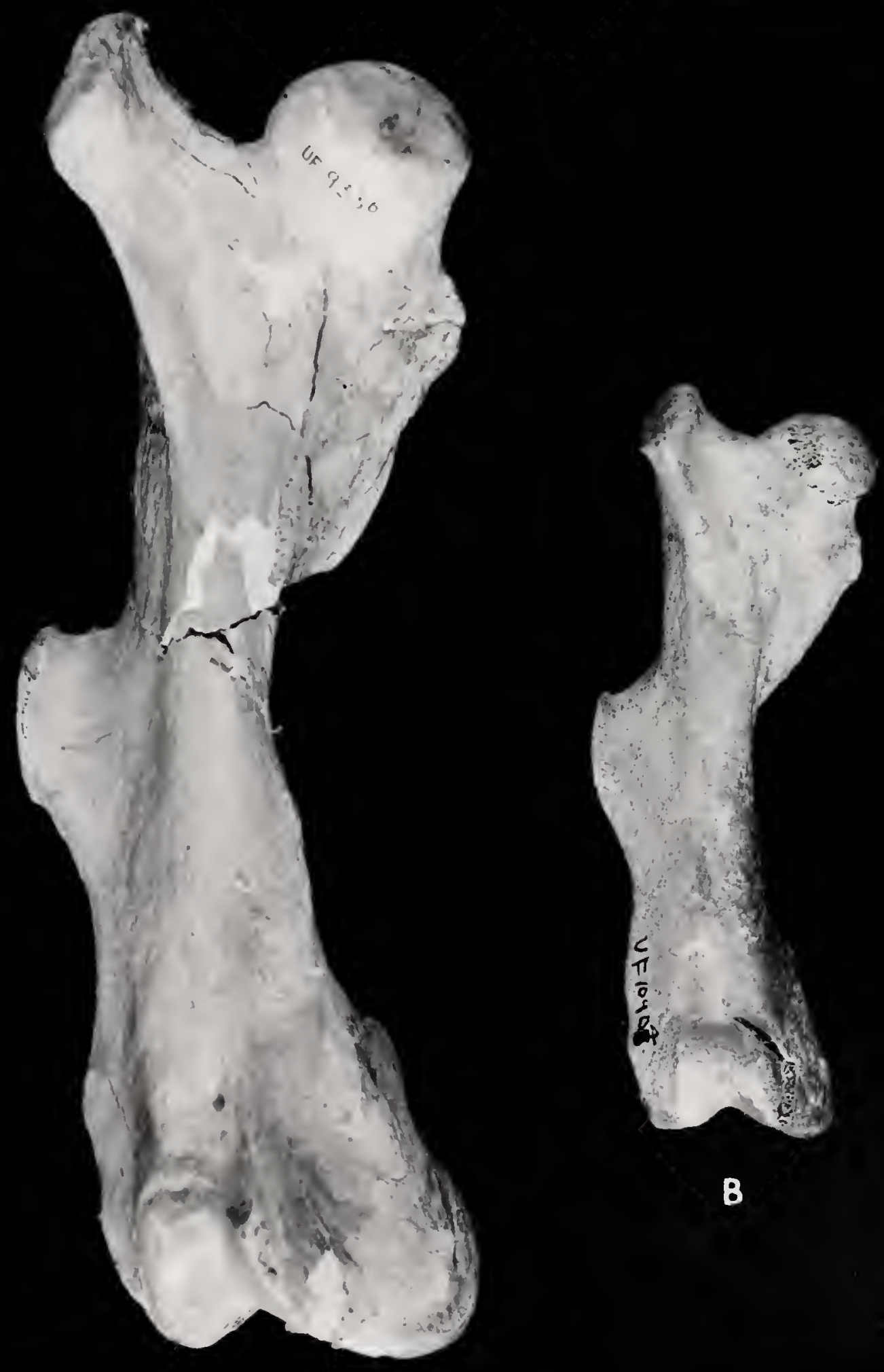

8

\section{A}


Figure 10

Kraglievichia and Chlamytherium Dermal plates

A. Kraglievichia paranesis, Haile XVN, Blancuir

B. ?Kraglievichia sp., Inglis IA, Eariy Jrvingtonian

C. Chlanytherium septentrionalis, Coleman ITA, late Irvingtonian

D. Chlamythexium septentrjonaiis, Branford IA, Ranciolabrean

X 0.40 (linear) 

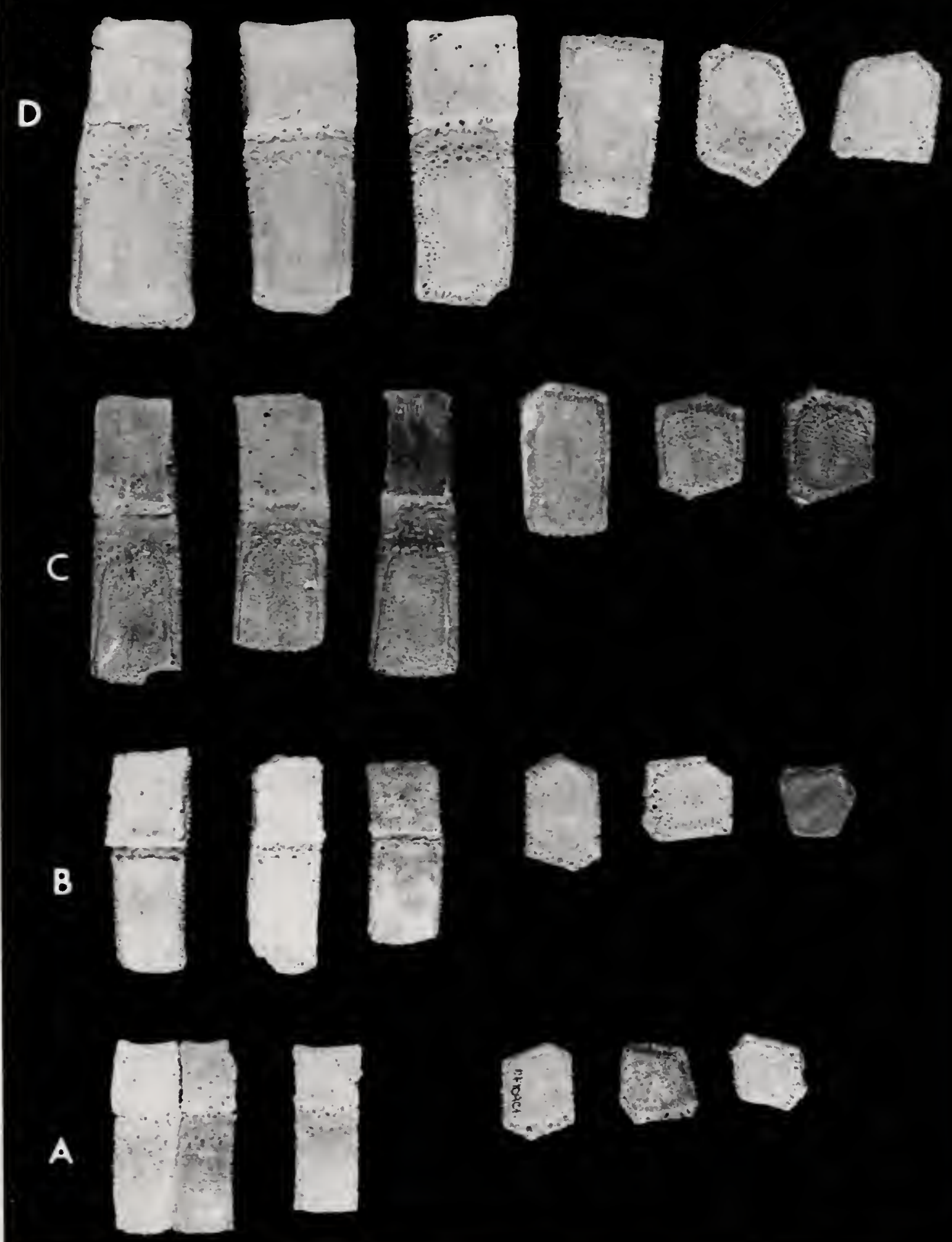
1.he later Irvingtonian Colomen I.t/ sjte, and the largest plates of all are those from the Jancholabrean I3ranford IA locality.

A trend from peg-like t:o bilobate teeth, and from ) blique to parallel tooth row axes was previously noted. Both of these trends secm to liavo extended from the rear of the dentition toward the front, as the number of bilobate and parallel teeth increases from Vassallia through Clllamytherium.

Concerning the geography of chlanythere evolution, it is apparent that these forms originated in Soutin America as all pre-pleistocene records of ihis group are restricted to that continent.

The earliest known Crilamythere is the Eocene Machlyantherium, and no chlamythejes are known fron the oligocrnes. Vassallia is present in Mincene deposits of South America, and both Vassallia and Kraglievi.chia were present in the South American Fliocene. Kraylivvichia is known from ivorth American early Fleistocene deposili, but its plesence in South America during the Pleistocere is guestionable. Chinmytherium is known from tise Fleistocerc of North and south America.

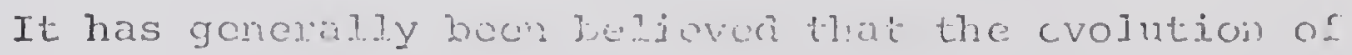

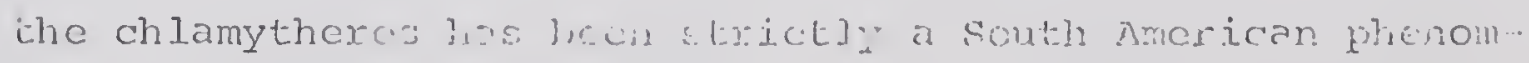


enon, with only the end product, Chlonytherium, migrating to North America duxing kancholabrean time. The evidence supporting this hypothesis is, briefly, that all pre-kancholabrcan records of chlamytheres have been from South America: and all genera of chlamytheres except chlanntherium secmed to have been restricted to South America. The study of the Faire XVA fauna: anci other pre--Rancholabrean sites of Wrorida, has yielded conclusive evidence warranting hodification oi this theoxy.

Ipparently Kraglievichia migrated to North fmerica shortly after the establishment of the late cenozoic land bridge between the two continents. This is substantiated by its presence in the Haile XVA and other Elancon fauns of Florida.

Three hypothesos can be offered regarding the zooge-ography of the evolutionary transition from kraglievichia to Chlamytheriun. The first hypothesis, a ready discussed, is that the evolution of Chlamytheriun took piace in south Amerias and this genus then moved into North Inerica in Rancholabrean times. This intepretation has already been shown to be in error.

The second hypothesis suggeses that Kraglievichia moved into noxth Anerice cur ing the latost pliocene and became oxtinct in sout morica. This rould mate the evolution of 
Chlamyllorium strickly a North Anerican event. According to this liykothesis, ChIanytherium, a North funcican form, then rrinvaded South America in the later pleistocone. Mis would accomit for the apparent lack of chlamytheres in the early pleistocene of South America.

The apparent lack of chlamytheres from the Argentinian Chapactmalalan fauna shoula be briefly discussed here. A dermal. plate has been questionably attributed to this; faurai (Kraglievich, 1.934); however, the specimen was from a local-ity near the major deposit and its horizor is actually unknown. Because of their unusually high number of brory plates available for preservation, if ihe chlomytheres wej. present at all in the fauna, they should be vell represicricu. It is possible that their absence from the fauna js ecolis. ically determined. The early fleistocene Chapadmalal faria reprcscnts a tomperate part of the continent, whereas ihe chlamytheres may have beer resiricted to the jore tropical. parts of the continent. The lack of early plejstocenc deposits in tropical South Amcrica hampers a ciefjnite estabIishrnent: of the presence or auserce of these forms on that contincis: at that time.

The third hypotinesis io be consjored is that the ain.tributzon of chlamytheses his hecn continuous nii both corn tjuchts thromehout the ploisturera, and the volution of 
Chlamythorium from Kraglievichia occurred simultaneously in North and South nmerica. That is the hyjothesis favored here.

\section{Dasypus hellus Simpson 1929}

Material: UF 16698, left nasal, right maxilla and mändible, right astragalus, 51 isclated dermal plates.

The preceding material probably represents one indiridual as the maxillary and mandible articulate nicely and al the material (with the exception of some of the plates) was found closely associated. Comparisons are made here with other specimens of D. bellus and with its closest living relative, Do novemeinctus. The only other known D. bellus material containing teeth is from crankshaft Pit, Missouri (UK 15544, oesch, 1967). Postcranial comparisons are made with material from a number of sites of various ages jri Florida.

The nasal bone is represented by only the anterior portion and is larger than, but morphologically similar to. that of p. noverncinctus.

In discussing the dentition, teeth will be designated

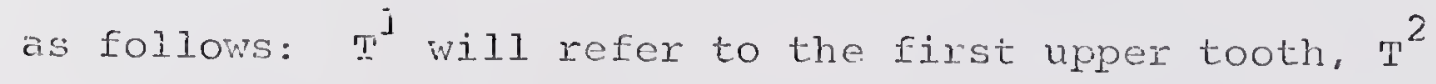
the second upper tooth, and so forti. The same procedure will be used in referring to the lower tecth.

we maxjlary is fragmonted ana concains only $r^{3}-T^{6}$. Fixcept for wize, the lateral portion of this speciiren con- 
pares favorably with the corresponding portion of the crankshaft pit specimen. The first three tecth of Ut 16698 wore probably transversely fiattened as this is the nature of $\mathrm{T}^{3}$. The remaining uppes teeth were probably rourd and peg-like as this is the conclition in $T^{4}-T^{6}$. The crankshaft pit skull is from a juvenile individual, ard $\mathrm{T}^{l}$ has not completely crupted. In this specinen the first tooth is transverscly flattened, but all the rest are round and peg-like. Ir D. novemcinctus the first three teeth tend to be somewhat. Jaterally filationed, but rot as much as in the Haile XVA specimen of D. bejJus. That tooth number and structure is variable in Dasyous has been pointed out by lalmage and Buchanan (1954), as well as by others. In four D. novencinctus skulls examined, the total number of teeth varied. from seven to nine.

The mandible of UF 16698 (Figure 11 ) is lacking the proximal end. The numbex, shape, and location of the nental foramina are highly variable in this genus. In both know D. bellus mandibles there are two foramina, one large and cne smal.1. In UF 15698, the larger of the two foramina

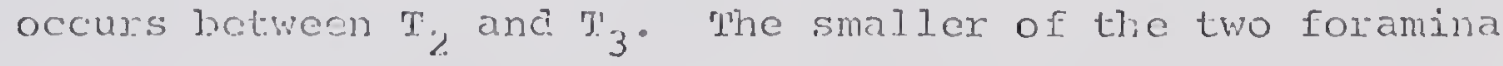
is locatcd 38 min anterior to $\mathrm{T}_{\perp}$. In UK 15544, the larger foramer is anterios to tho smaller and is located direcily

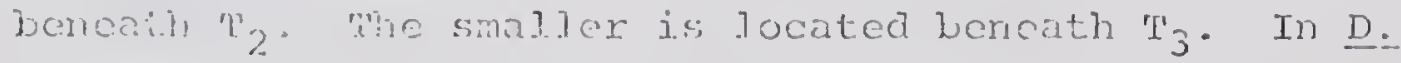


Figure 11

Dasypus bel Ius Mandible

UF 1.6698, Ha.i]c XVA

x 2.26 (Ijinear) 


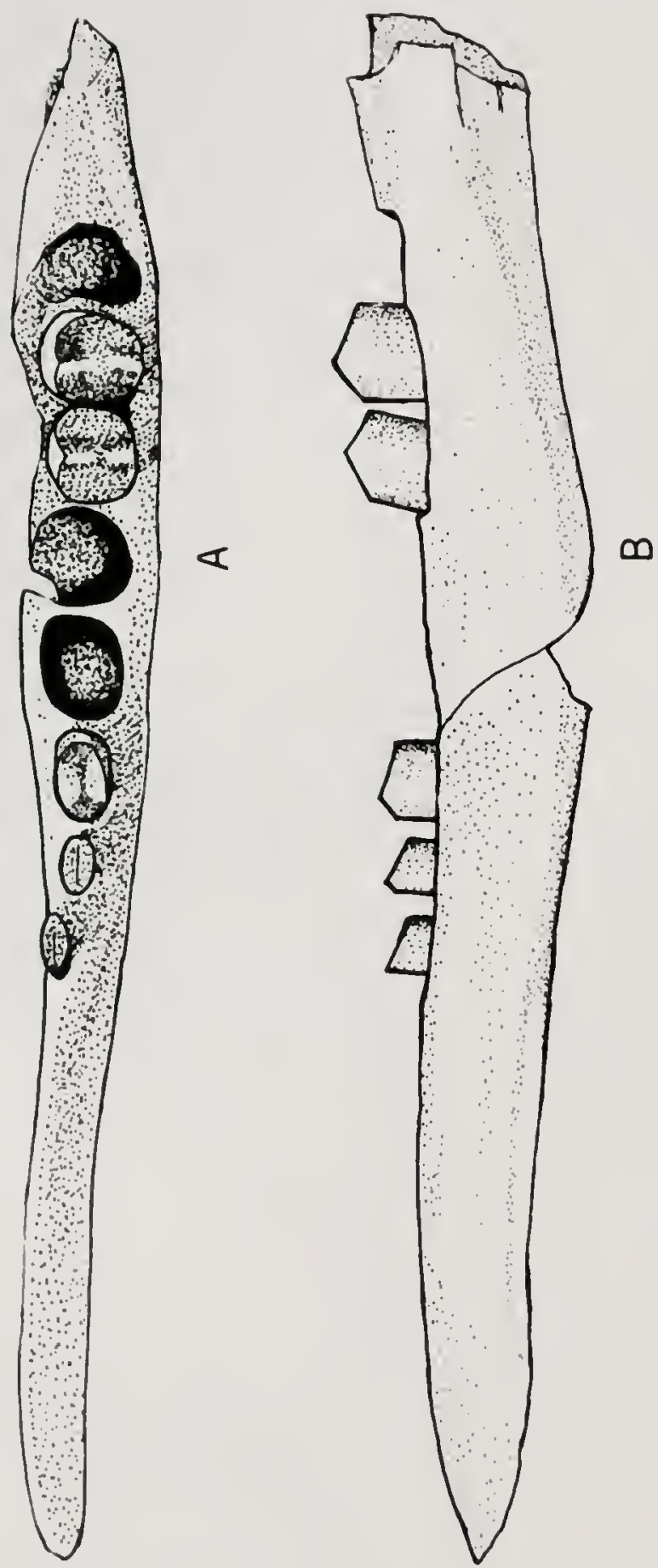


novemeincius, the number of mental foramina varies from one to fous. The symphysis of the Haile XVA specimen is weak, which is characteristic of the genus.

The mandilole of UF 16698 Iacks $\mathrm{T}_{4}-\mathrm{T}_{5} \cdot \mathrm{T}_{I_{1}}-\mathrm{T}_{3}$ are laterally flattened bui ${ }^{6}$ and ${ }^{r_{7}}$ are round. This differs from the lower äentition of UK 155,4 in which all the tecth are round.

Except for smaller size and a tendency toward ilattening of the anterior teeth. the mandibles and dentition of the Haile XVA specimen differ little from othor Dasypus materiai. Denial measurements are provided in rable 9.

Differences in the astragalus of the Haile XVA D. Del ?ug and other specimens of D. bellus from various Florida Plejstocene sites and Recent specimens of D. norcrncinging are insignificant except for size. A comparison of the astragali of Dasypus from various stages of the pleistocene reveals a size trend similax to that of the chianytheres, with one exception (Fjgure 12). The size of Dasypus increascd from B.tancan through Rancholabrean time, then decreased in Recent times when it is represented by D. novemcinctus.

The dernal plates of Ur 16698 do not differ from any other specimens of Dasypus ex:coi for size. Martin (in pross) has mosured semples of plates from sovoral filorida 
Dental Measuremants (in mm) of Dasypus bellus

Maxillary

Total distance, tecth 3-6

Anteroposterior distance, tooth 3 Transverse distance, tooth 3

Antcroposterior distance, tooth 4 Transverse distance, tooth 4 Anteroposterior distance, tooth 5 'Transverse distance, tooth 5 Anteroposterior aistance, tooth 6 iransverse distance, tooth 6

Mandible

Depth of ramus at tooth 1 Width of ramus at tonth 1 Depti of ramus at tooth 6 width of ramus at tooth 6 Depth of ranus at tonth 8 widith of ramus at tooth 8 Length of tooth row

Anteroposterior distance, tooth 1 Transverse distance, tooth ]. Anteroposterior distance, tooth 2 Transverse distance, tooth 2 Anteroposterior distance, tooth 3 Transverse distance, tooth 3 Anteroposterior djstance, tooth 4 Transverise distance, iooth 4 Anteroposterior distance, tooth 5 Transverse distance, tooth 5 Anteroposterior distancc, tooth 6 Transverse disiance, tooth 6 Mrteroposterior distance, tooth 7 Iransverse distance, tooth 7 Antcroposterior aistance, tooth 8 Transverse distance, tooth 8

$\begin{array}{ll}\text { UF } 16698 & \text { UK 1554. } \\ \text { Haile XVA } & \text { Crankshaft Pit } \\ \text { Florida } & \text { Missouri } \\ & \text { left right }\end{array}$

$\begin{array}{rrr}19.9 & 23.8^{1} & 23.7 \\ 3.5 & 4.6^{1} & 4.5 \\ 2.1 & 4.6^{1} & 4.5 \\ 4.4 & ---. & ---- \\ 3.6 & ---- & ---- \\ 4.0 & --- & 4.1 \\ 4.2 & ---- & 5.1 \\ 4.2 & 5.2^{2} & 4.5 \\ 4.1 & -\cdots- & 4.8\end{array}$

6.8

12.4

2.8

$---$

3.7

8.4

4.8

7.2

5.2

15.2

].5. 5

8.2

7.8

i2.?

6.4

38.8

13.5

7.1

45.6

3.0

1. 3

3. 3

1. 4

3. 3

2. 2

$4.8^{1}$

$2.8^{1}$

$4.0^{2}$

$3.3^{2}$

4.5

3.7

4.6

3.5

4. $1^{1}$

$4.2^{2}$

$2.8^{3}$

$1.8^{2}$

2.2 2.1

$2.7 \quad 2.3$

$4.0 \quad 4.5$

$3.2 \quad 3.2$

$4.7 \quad 4.6$

4.54 .2

4.14 .4

4.54 .5

4.34 .5

$4.7 \quad 4.7$

$4.6 \quad 4.2$

$4.7 \quad 4.6$

3.53 .4

$3.5 \quad 3.4$ 
F'igure 12

Dasypus loelius Fstragali

A. UF 16698, Haile XVA, Blancan

13. UF 13187, Coieman IIA, Irvingtonian

C. UT 2478, Mefford Cave, Rancholabrea

X 2.23 (2inear) 

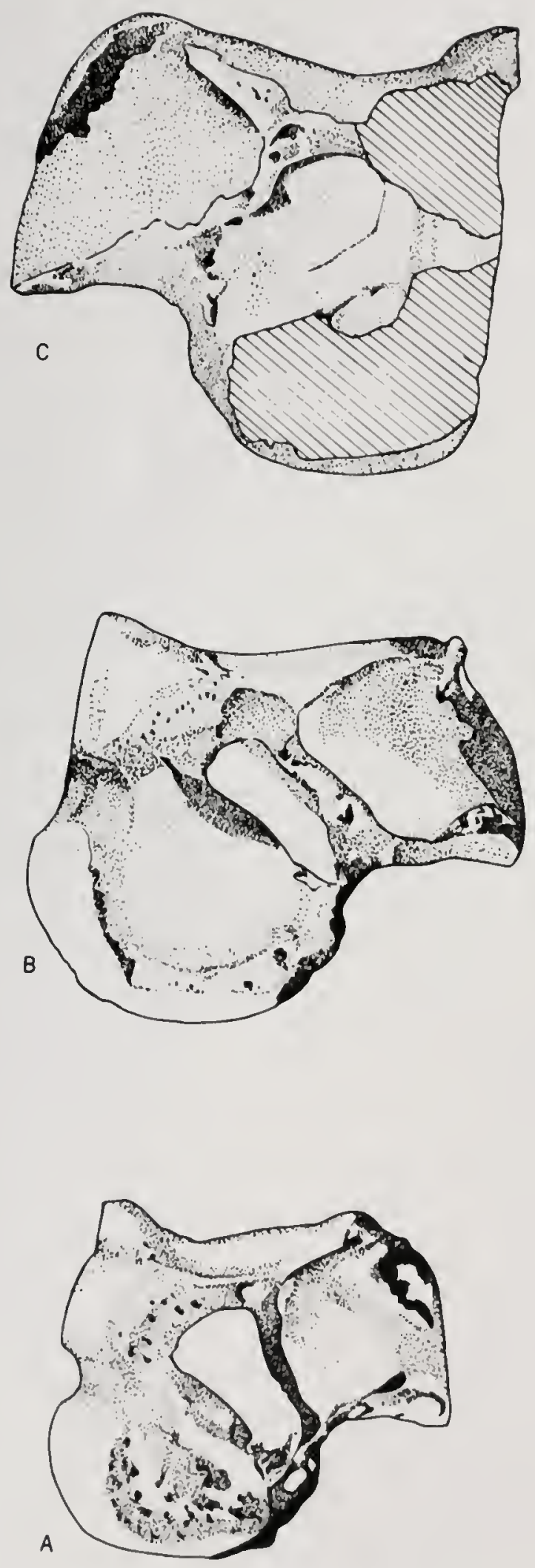
sites ara has shown little overlap in plate size between D. bellus and D. novemcinctus. His measurements indicate that the size of the plates do not follow the trends throughout the pleistocene which are seen for other paxts of the skelcton. The Coleman III 1) ates are small, and overlap slighely with those of D. novemcinctus. However, this was probabiy due to the small sample of plates used. There are approximately 2,500 plates in a single armadillo carapare and little or no satisfactory method for determining the area of the shell from which most of them come. Therefore, size trends based on plates should involve large samples to insure accuracy.

Inasmuch as the morphological differences between the Haile XVA material and other D. bellus material are so sight, and those which were observed probably represent inaividual variation, this material is referred to Dasypus belius.

Dasyrus bellus has typically been considered a southein North American species of Rancholabrean are. Martin's (in press) description of the coleman IIA fauna, however, ox-. tended the temporal range of the species hack to Irvingtonian time. This repori extends this species still further back, into the 31 ancan, and is thus the creliest known record. There is a quostion as to the melationship botween D. 
bellus and D. novemcinctus. These animals are clearly more related to cach other than to any of the other armadillos (Auffenberg, 1957). The question axises as to whether D. rovemcinctus was derjved from D. bellus or existeà allopatrically with D. bellus auring the Pleistocene, replacing it during the Jast few thousand years.

Considering the former possibility first, it would have taken quite rapid seiection for smaller size to devclop D. novemainctus from D. bellus. In Miller's cave (Pation, 1963), a date of: ca 8,000 BP is given for the Travertine stratum bearing D. bellus remains, and a date of ca 3,000 BD for the Brown Clay deposits containing D. noverncirctus. According to patton (persorial communication), even if the D. novemcinctus is a Recent intrusive (which he doesn't believe to be the case), the difference between 8,000 E? and 3,000 BP, or 8,000 $\mathrm{BP}$ and J,000 BP is not that great-it is still rapid cvolution, but possible, particularly if the only change is size.

Conceming the second hypothesis, if D. novemcinctus existed somewhere else during the pleistocene and replaced D. bcllius very late, j.t slould be jnown fiom some contral or South merical Pleistccene deposit. To date, however, D. novemejnctus häs no fossii xccord excopt for Miller's

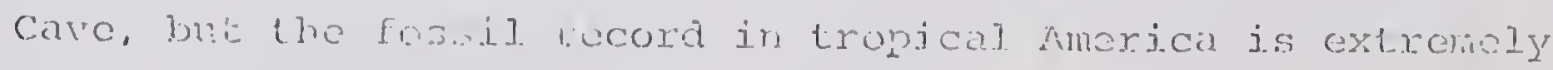
poo:. 
That D. balius is not known from pre-Rancholdbrean deposits outside plorida is puzzling. Slaughter (1961) lists two conditions which he foels were necessary for the occur-rence of this species: winters could have been no more severe than those of North Centrai rexas today; and rainfall probably had to be more than 20 inches per year. That temperature and rainfall could have restricted D. bellus to Florida during the entire pleistocene is possible, hut it seems more likely that the known distribution of this species is a reflection of a lack, outside of Florida, of Gulf Coastal plains sites of the proper age.

order Lagomorpha

Family Leporidae

Sylvilagus sp. Gray 1967

Material: UF 17561, $2 \mathrm{M}^{3}$, UF $17562, \mathrm{M}_{3} ;$ UF 17563 , lumbar vertebra; UF 17564, 3 innominates; UF 17565, 2 femora; UF 17566, 1 tibia; UF 17567, 2 metatarsals.

Hypolagus and Sylvilagus are: two smaller lagomorphs common in North American Blancan deposits. Unfortunately, the generic diagnesis provicied for IIypolagus by Dawson (1958) does not inciude discussion ot either $\mathrm{M}^{3}$ of $\mathrm{in}_{3}$, which are the only teeth preserved in the Haile XVA fauna. A comparison of the innominates from flaile XVA with the descriptions and figures of these elements of Iypolague in bawson (1958) 
shows the llajle specinens possess a less elevated jlital ciest, a condition considereả to be more advanced. All the rest of the maile XVA material also agrees in size and morphology with Sylvilaquis.

Unfortunately, a lack of diagnostic elenents prevents a species deternination. Two living spcoies are present throughout Florida: S. palustris and S. floridanus. The prosent range of the gonus is throughout North America, with two species being present in South Anerica: S. floridanus and S. brasielchsis (Hall and Kelson, 1959).

Previous Blancan records of Sylvilagus inclide the Curtis Ranch fauna. (Gazin, 1942) and the Broaäwater fauna (Baibour and Schultz, 1937). Numerous Irvingtonian ana Rancholabrean occurrences of this genus axe recorded througl-out lorth America.

Order Rodentia

Family Sciuridae

Petauria sp. Dehm 1962

Material: UF 12353, partial right mandisle with is. by Mioccne lime flying squirrels had diversified into two gruups (James, 1963). One of these groups has complicater dreek tooth Inph patterrs. This is due to the presence of "protoloplnles and motinlophules, and cspcoiolly meta-

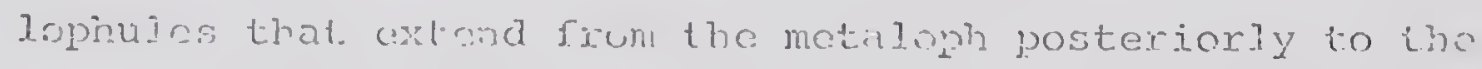


posierior cingulum, dividing the posterjor valley into two, and sometimes three or more smaller valleys." (Janes, 1963) This complicated toothed group contains several Iiving genera incluaing peiaurista. Belomys, Progopterus, and Sciuropterus, as woll as the fossil genera pliopeiaurista (Kretzoi, 1959). Petallia (Dehm, 1962), and Pliosciuropterus (Sulimski, I964). The second group has simpler loph patterns in its cheeli teeth. This group is represented by the living genera Hylopetes, Aeromys, Eoglaucomys, Glaucomys, and others, and by the extinct genus pliopetes (Sulimski, 1964) and several exinct species referred to sciuropierus.

Formerly, Fossil species referred to Sciuropterins included both simple and compler toothed types. Hugueney and Mein (1965), however, have placed the complex toothed fossil spocies of Sciuropterus in the genus pliopetaurista basca on Deperet's (1897) S. pliocenica. The result is that all fossil species remaining in the genus Sciuropterus in both the New and the old world have simple teeth, while the liviny species which are restricted to the old World have compli-cated teeth. This curious arrangement leaves some doubt as to the evolutionary unity of the fossil and recent species rejerrea to scinropterus.

The yaile XVA specinen (Figures 13 and 14) marks the

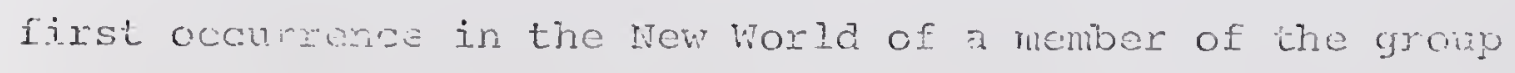


Figure 13

Petauria sp. Right Mandibie

UE 12353, Haile XVA

X 7 (1inear) 


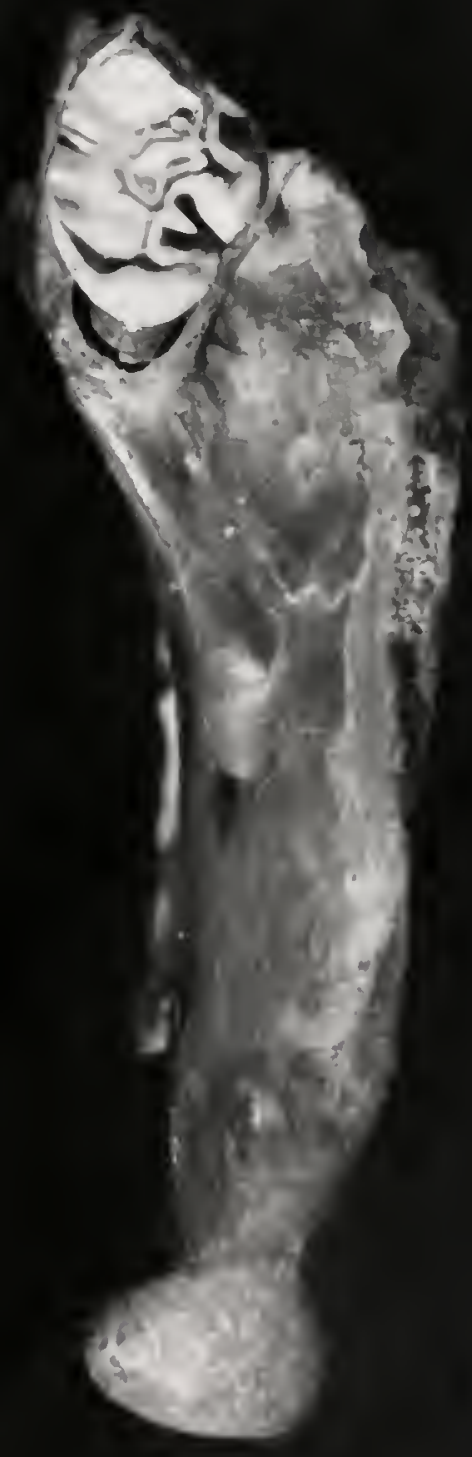


Figure 11

Petauria $s p$. Right $M_{3}$

UF 12353, Haile XVA 


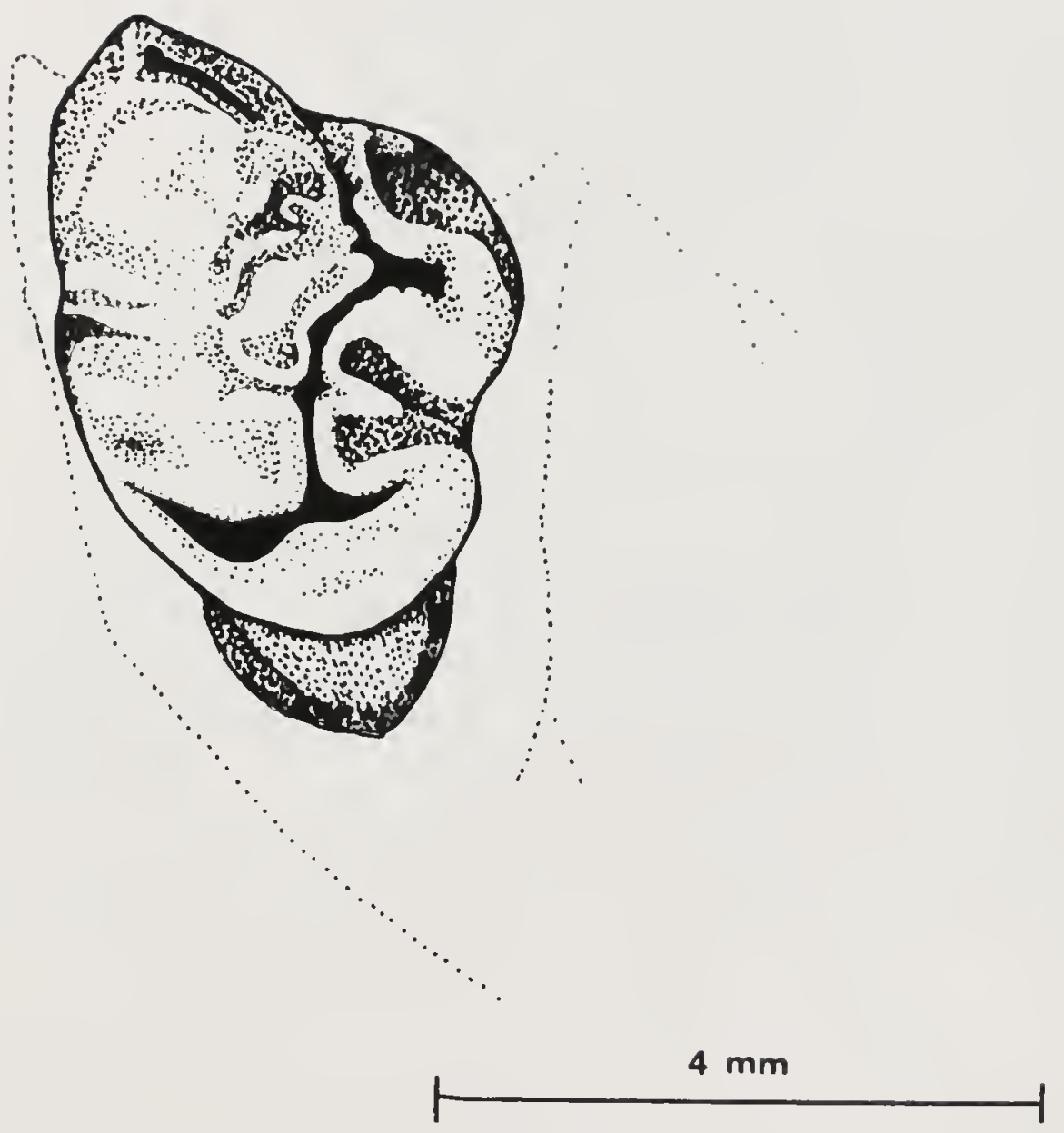


with complicaticd tecth. It is clearly mure closely related to petaurista than any of the other jiving genera.

The Haile XVA specimen (Ut 12353) aiffers from Plio... petauisia in that j.ts $H_{3}$ is oval in shape as opposed to being pointed at the posterior end. 'line metastylid in UF 12353 js only moderately developed as opposed to being well developed in pljopetaurista, and the postflexid is not as we1. developed in the Haile XVA specimen.

UF 32353 differs from the $M_{3}$ of pliosciuropterus in its shape, which is narrow and tapers toward the postorior end. as opposea to being oval in the Haile XVA specincr. Ihe mesocoljich jis only moderately developea intlie Haile XVA specimen wile in pliosciruopterus it is so vell develofod that it forms a labial spur. The postflexid is also we.l developea in piosciuroptexus.

UF 12353 is clearly more allicd with petanria then any of the rossil. genera. On the other hand, one striking difference separates these forms: the mesocnid is completelif alsscnt in petauxia, but it is modeiately well developea in the Haile XVA form (Figure 13 and I4).

The lizilc XTA spocimen shares one inmoutant characteristic with petauristo that does mot occur in poternad, namejy the presence ot: a mascoonit. (1) the other band it stares the followive charactoristics with Putovia mich do not 
occur in petanrista: the grinding surfuce of the talonid is less complex; and the metastylid is moderately developed as opposed to the netaconid-metastylid chaos (McKenna, 1962). Finally, it shares the following characteristics with both Petaurista and Petauria: the grinding surface of the trigonid is complex, with extra lophids and fossetidis; the postflexid is poorly developed; the $\mathrm{M}_{3}$ is oval in shape; and the entoconid is connected to the hypoconid through the hypolopilid.

Since the Haile $X_{V A}$ specimen shares characters with both Fetaurista and Petauria, assignment to a genus is dif.. ficult. Whether the lack of a mesoconid is more important than the presence of extra fossettids and lophids on the talonid would probably be a disputed point among stuảents of rodent cvolution. However, petauia is known from only one dentition, and the variations which may have existed are not: known. Petaurista, bcing extant, has been studied in greater detail and its variations have been taken into accomit. 'I'hus characters known to be peculiar to petaurists are more reliable than those in the diagnosis of Petanria. The simple grinding surface of the talonid (not olservea in a very large sample of Petaurista) becomes a more important character with regard to the Haile XVA specimbur wan the mesence of the masoconid, which may 
have occurred in petanria. Following this line of reasoning, it secms more appropriate to refer the Haile XVA specimen to Fetanria.

The only specinen of petauria previously known is from Bavaria, in the Region of Eichstatt. The deposit was a fissure filling of red loany sand in the Solcnhofn Limestone. The filling has been ascribed to the "older pleistocene" by Dehm (1962).

It is almost ceriain that the populations of fiying squirrels of Florida and Bavaria during the early plcistocene were reproductively isolated; thus the Haile XVA specimen isnot assjgned to the type species, p. helleri. It also seems pointless at this time to describe a new species based upon this single specimen, as even the generic characters are difficult to ascertain with this Iimited amount of material. Until more material is available, it seems mose prudent to refer to the Haile YVA specinen as Petauria sip.

\author{
Familir Castoridae \\ Castor caraacnsis Linnacus 1758
}

Materiai: UT 17489, left fums.

This element, lecking the proximal end, represents a young individual. It shows no morphological differences from the riving specier, A comparison of measurements 
(Iable 10) with examples of young, Recent c. canadensis shows no significant size differences. Other Blancan records of Castor are the San Joaquin locality (Kellogg, 1911; Stirton, 1935) and the Hagerman fauna.

Family Cricetidae

Sigmodon medius Gidley 1922

Material: UF' 12335, left $M^{1}$; UF 12341, right $M^{1}$; UF 12337, left $M^{2}$; UF 12339, UF 12340, right $M^{3}$, UF 12334, UF 12338, left $\mathrm{M}_{1}$; UF 12336, left $\mathrm{M}_{2}$; UF 12342, right $\mathrm{M}^{1}$ and $\mathrm{M}_{3}$ (both univorn).

This species characteristically possesses only two or three roots on the $\mathrm{M}_{1}$. If accessory roots are present, they are centrally located and are very small, peg-like structures. The labial roct is always better developed than the lingual. The two specimens from Haile XVR, UF 12338, agree with the above features.

Sigmodon medius is nearly identical morphologically with a closely ailied species, sigmodon minor. According to Martin (in press), the only difference between the two species, other than size, is that the re-entrant folds are deeper and narrower in S. minor than in s. medius. This character is more obvious in tceth with little wear and since the essential Haile XVA specimens show significant vear, sise ainne nust be relied upon for the separation of 
Table 10

Measurements (in $\mathrm{mm}$ ) of the Femora of Fossil and Recent Castor canadensis

Wiäth, distal end

Anteroposterior depth, distäl end

Width, exiernal condyle width, internal condyle wirith of shaft at third trochanter

Anteroposterior diameter of shaft at third trochanter
C. canadensis C. canadensis UF 17489 Recent

Haile XVA $N \bar{x} \quad$ O.R. $38.7 \quad 6 \quad 36.6 \quad 34.1-38.4$ $29.2 \quad 6 \quad 29.7 \quad 28.5-32.5$ $13.5 \quad 5 \quad 14.0 \quad 12.2-15.5$

$\begin{array}{llll}12.5 & 5 & 12.1 & 11.6-12.5\end{array}$

$25.2 \quad 6 \quad 29.2 \quad 27.0-30.5$

$\begin{array}{llll}13.9 & 6 & 11.5 & 10.2-13.5\end{array}$ 
these two species. Sigmodon medius is significantly larger than S. minor. The Jarger measurements of the Iraile XVA matcrial (Table 11) indicate that it belcngs to s. medius.

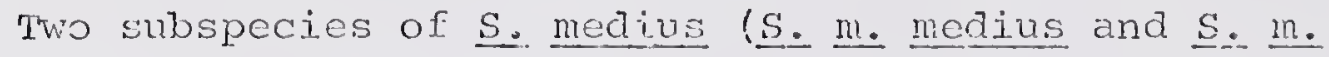
hibbardi) have jeen described, based entirely upon sjze difference. The small sample of material from Haile xva, however, prevents the statistical treatment necessary to determine the subspecies designation.

Sigmodon medius is known only from Blancan deposits of North America. These include the Benson fauna, the Vallecito-Fish Creek sequence (Downs and white, 1968), the Red Light Local Fauna (Akerston, 1970), the Hudspeth fauna (Strain, 1966) and tre Broadwater fauna.

$$
\begin{aligned}
& \text { Order Carnivora } \\
& \text { Family Canidae Gray } 1821
\end{aligned}
$$

Material: UF 17492 and UF 17493, 2 tibiae. The presence in the fauna of two poorly preserved tibiae probably represents the Family Canidac. They are about the size of a fox, but positive identification is not possibie as only the badly morn proximal ends are preserved.

Family Mustelidae of Pteronura Gray 1837 


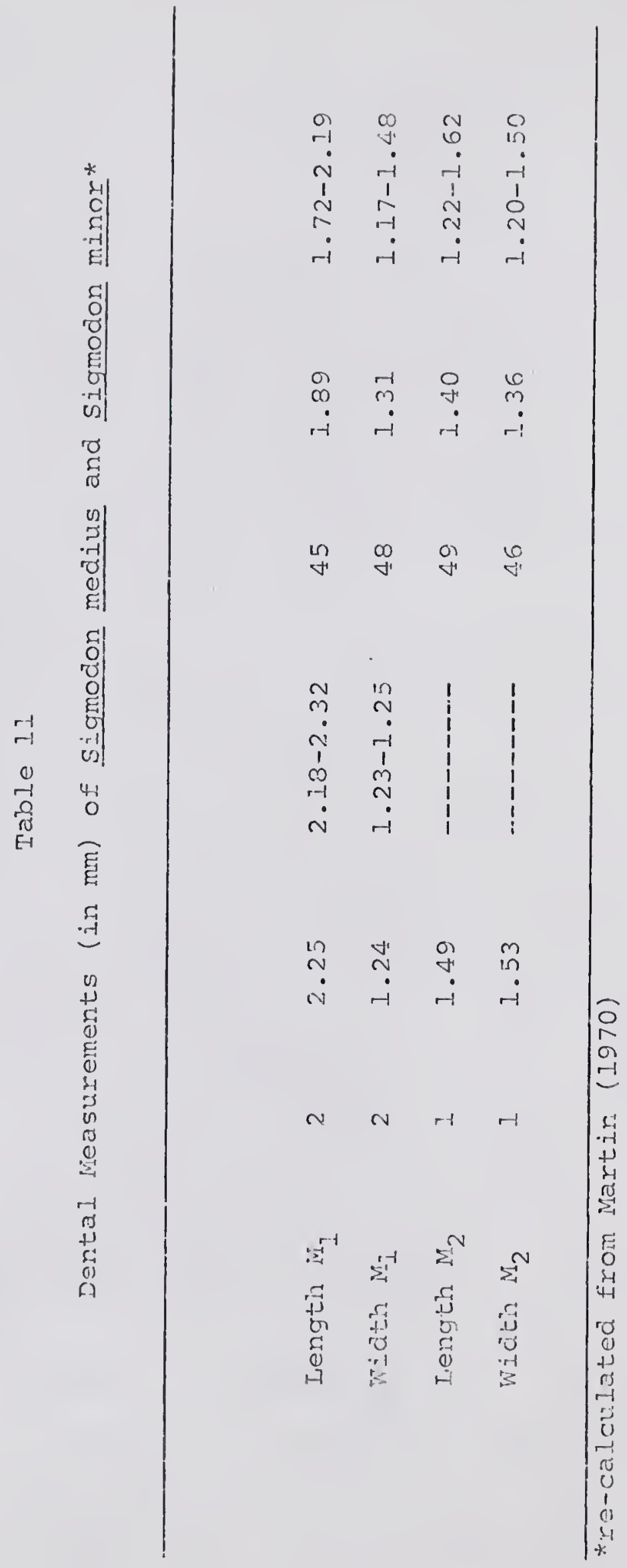


tarsal II; UF 17490, right metatarsal III; UF .17494, niedial. pinalanx.

The humerus (nigure 15) is lacking the proximal end and the distal end has a pathologic abnomality. The element is very porous in the region of the olecranon fossa and on the Jateral and medial edges of the distal end. The abnormal growth of bone on the medial siate of the distal end has resulted in a downward extension of this portion of the humerus to a greater degree than is usual. This growth (and possibly a similas. abnormality in the ulna) has caused al sinite in the articular contact between the humerus and the ulna. The result of this shift in articilar bearing presm sure was a "planing off" of a postion of the distal ar-ticular surface.

Disregarding the abnomalities of the element, it correspendis very closely morphologically with both utura and Ptexonusa. A possible differcnce between these two genexa. other than size, may exist in the shape of the entepicondy lar foramen. In pteconura the foramen is nearly round, while in Iutra it is elongate. The Haile XVA specimen more closeIy agrees with Pteronura. A length/width ratio of the measurements of the foremen shows the following results: Haile XVA specimen 1.3; Ptosnura 1.4; and Intre 2.2. It should be pointed out, however, that this character is likely to 
Figure is

Pteroruya humaxus

UT? 17487, Haile XVA

X 1.85 (lincar) 


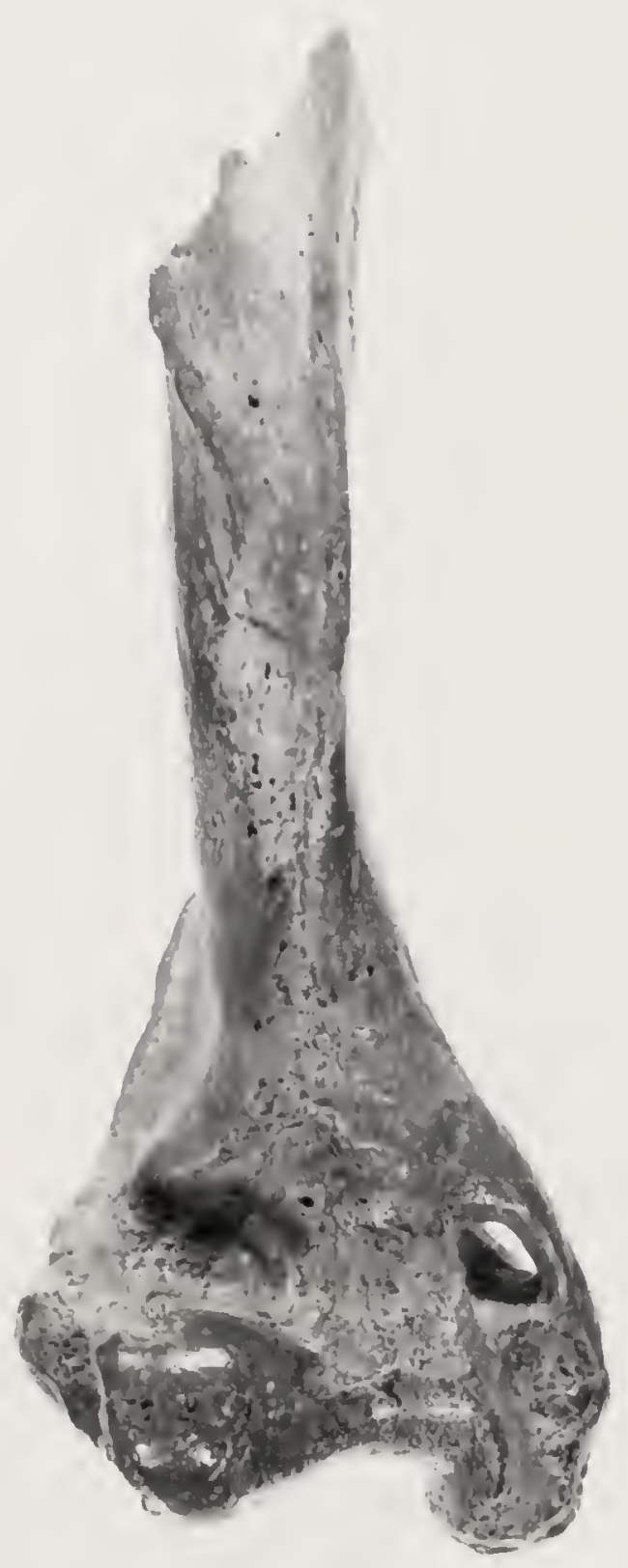


be highly variable, as one of the specimens of Isutua studied compleiely lacked this foramen.

In size tlie Haile XVA specimen also agrees more closcly with pteronura. The majority of the measurements of this specinien agree with the measurements of threc pteronura specimens and were exclusive of the range of measurements of seven Lutra specimens (Table 12). Nonctheless, the relatively small samples gives cause for some reservations, and thus the Haile XVA specimen is only tontatively referred to Pteronura.

Family Felidae

Smilodon gracilis Cope 1880

Material: UE I7496, right tibia (distal end) and righi: astragalus; UI .7498 , right metacarpal II.

Ihis naterial represents a meaium-sized cat and is probably from ore indivjdual siuce the tinia and astragalus articulate wel.l, all the material is similarly preservoä, and all the elemonts were found Logether.

The material is referred to the genus Emjlodon on the basis of tro characters presented by Merriam ard stock (1932). First is the prescnce of the astragalar foramen. Second, the redial facel for the cilcancum and the facct for the navicular are merged. 


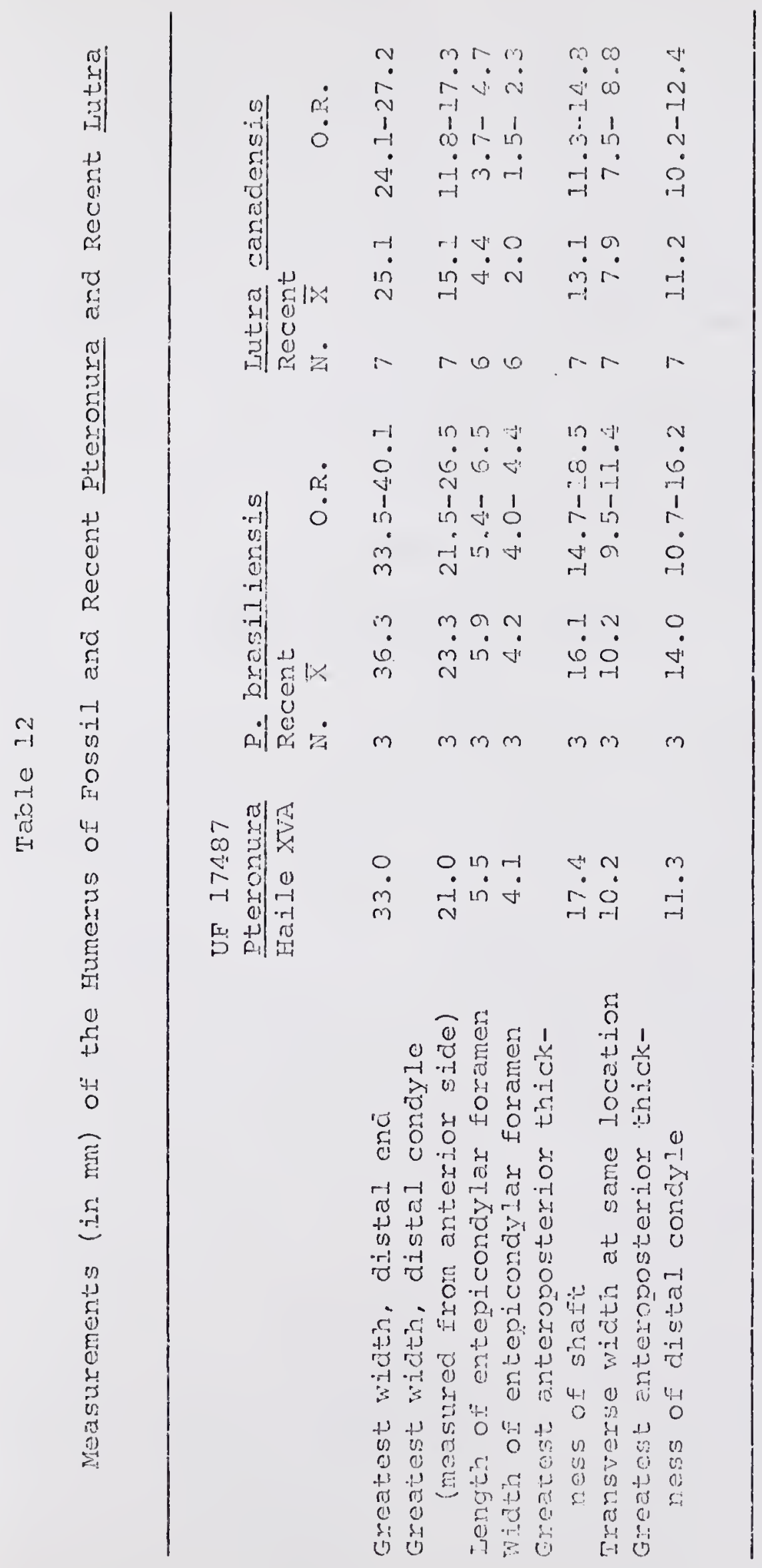


in size to smilodon gracilis. A comparison of the moasurements of the astragalus from Hajle XVA with thosc of the astragalus of S. graci]is from port kenredy Bone Bea (Cope. 1899) shows a close correlation in size (Table 13). Inasmuch as $\mathrm{S}$ gracilis is the only small species of smilodon in North America, the Haile XVA specimen probably represents this species.

Two species of small sabercats are known from south America. Smilodon crucjens is known only from a single mandible (Ameghino, 1904). Smilodontodon riggi (Kraglicvich, 1948) is prescnt in the Chapadmalal Fauna and is known cnly irom postcrarial material. This form is slightly larger than the Hajle XVA form. The astragaluis j: preserved in this specimen but it is in poor condition, and the critical characters of the facets cannot be verifica from the figures. While other species are shared by the Chapadmalal fauna and the vaile XVA fauna, it does not follow that the two cats are necessarily allied. The Haile XVA astragálus so closely resembles Smilodon that if it is the samc ess the chapadmalalan form then the chapadmalalan form must be synonymized with Smjlodon.

order proboscides

Family comphothuridae cabrera 1929

Miatcrial: UE ?7464, a small portion of a molar and two sma 3.] pirces of ivryy. 
Trable 13

Measurements (in mm) of the Astragali of Smilodon gracilis From Haile XVA and Port Kenneciy*

Haile XVA Port Kenneajy

uJ 1.7496

Iiengit,

41.6

48

width

45.2

38

wiath of troclilea

28.7

27

vertical diameter of head

18.7

17

Tryanserse diameter of head

26.6

2.5

Fxternal elevation of trochlea

21.1

22

imeasurements after cope (1899) 
The complicated nature of the tooth clearly jndicates that thjs specimen belonged to a gomphothcisid. Further identification is not possjble becausc of the sma.ll amount of material available.

\section{order perjssodactyla \\ Family Equidae \\ Nannippus phlegon Cope 1892}

Materia]: UF 17484, and UF 17485, both upper cheok teeth; UF 17547, metapodial; UN 17548, proximal jhalanx: UF 17549, four ungual phalanges.

The relatively unworn check tooth indicatas this form was strongly hypsodont. The other tooth (Figure 16) ano the postcranial material agree in all respects wit? the typical Blancan species, N. plilcgon. Measurements are piovided in Table 14.

\section{Plesippus simplicidens}

Material: UF 10909, partial skull; UF 1.7556, pastial maxilla with deciduous molariform tootr; ur j0894, 15 cervical vertebrae; UF 10877, 37 thoracic vertcbrae; UF 10895, 13 lumbar vertebrae; UF 1.0396, 2. sacral vertelsac; UF 10898, 3 humcri (2 left, I right); UF 10919, 1 right radius; Ui 10910, 2 left pelvos: Up 10913, i femola (2 loft, 2. right); UF 10915, ? right metatarsals; US 10921, 9 splints; uj logín, c criajods (2 Ieft: 2 rjght); Uf 10917,3 calcanea; 
Figure 16

Nannippus plilegon Upper Molar UF 17484 Haile XVA

X.4.4 (Iinear) 


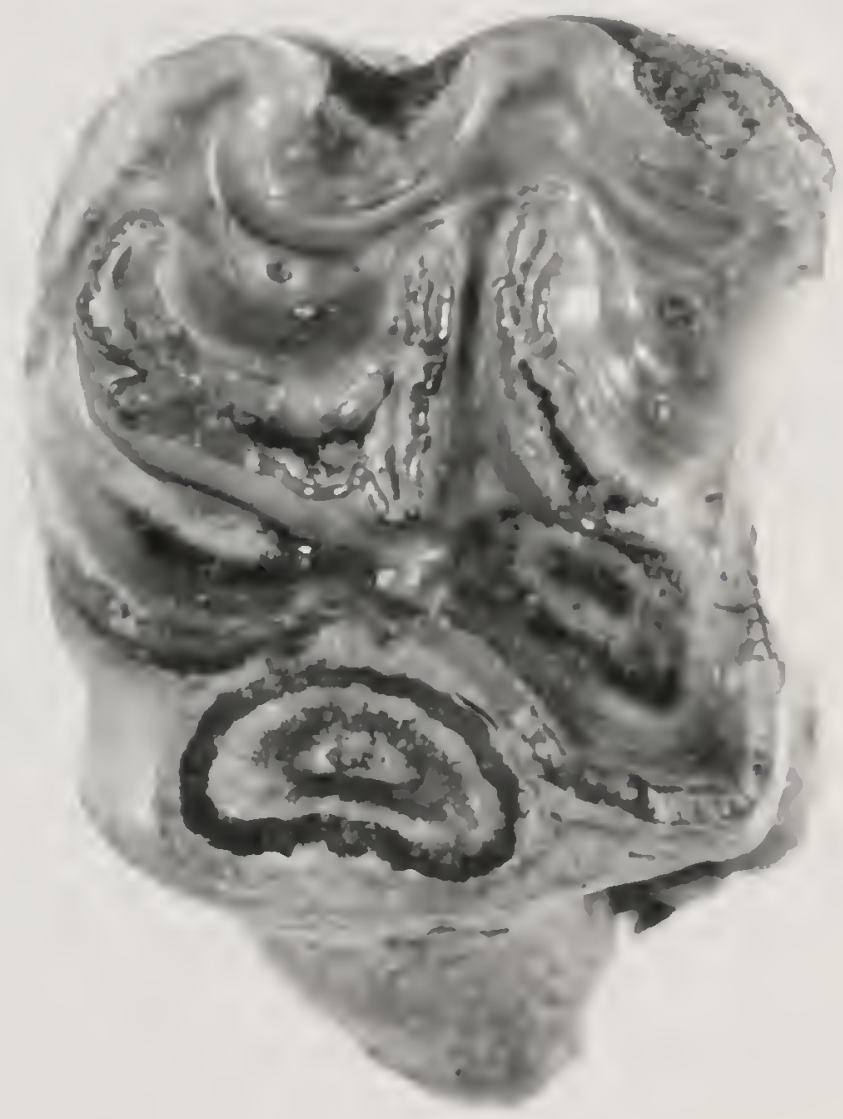


Measurements (in mm) of Nannippus phicgon Cranjal and post-sianial Material From Haile XVA

Upper cheek tooth

Anteroposterior distance

'Transverse distance

crown heiglit

\section{Metapoclial}

Transverse widith, distal end

Anteroposterior width, distal

ená

Proxima. P’alanx

width, proximal end

Widtī, distal end

Ungual Phalanx Total lencytin

width, distal articular

surface

$\begin{array}{cc}\text { UT } 17484 & \text { UF } 1.7485 \\ 17.5 & 19.6 \\ 20.4 & \ldots \ldots . \\ \cdots .-- & 51.0\end{array}$

25.7

24.0

24.4

20.6
UF 17549a UF 17549b UT $17549 \mathrm{c}$ 43.4 43.6

4.3.

22.7

23.9

22.8 
Uy: 10920, 2 astragali; UF los 17, 4 proximal phalanges; UP 1.0913, A distal sesamoids; UF 10914, 7 ungual phalanges. The Haile XVA skull (UF 10909) is in poor condition. and not enough of the fragments are present to allow complete re-construction. Both left and right dentition, hovever, are complete (Figure 17) and a portion of the prenaxillary has been rebuizt. A small portion of the cccipital reginn is preserved hut the rest of the skull consists of isolated fxagments.

The skuld is referred to the genus Elesippus on the hasis of the well developed $\mathrm{p}^{l}$, the poorly developed para-styles and metastyles, the dilation of the fossettes, and the more rounded nature of the protocones.

In dental morphology, UF 10909 resembles both plesjpins shoshonensis and Plesippus simplicidens. Gazin (1936) stites that the ranges of measurements of these two species overlap though E. Simplicidens tends to be smaller. The Haile XVA materias. (Table 15) is smaller than any of the individuals measurea by Gazin (1936). It is, however, about the sizc of the specimer of: P. Sirnplicidens described by Hibbard (1941) from the Blancar Reyrcad fauna of Kansas. The postcranial matcrial is also small (rable 26 ), and falls within the vange of neasurements fou p. Sjmplicidens provided by Gazin (1.936) 
Figure 17

Plesippus simpliciỏens upper Dentition UI' 10909, Hai.le XVA

(slightly less than natural size) 

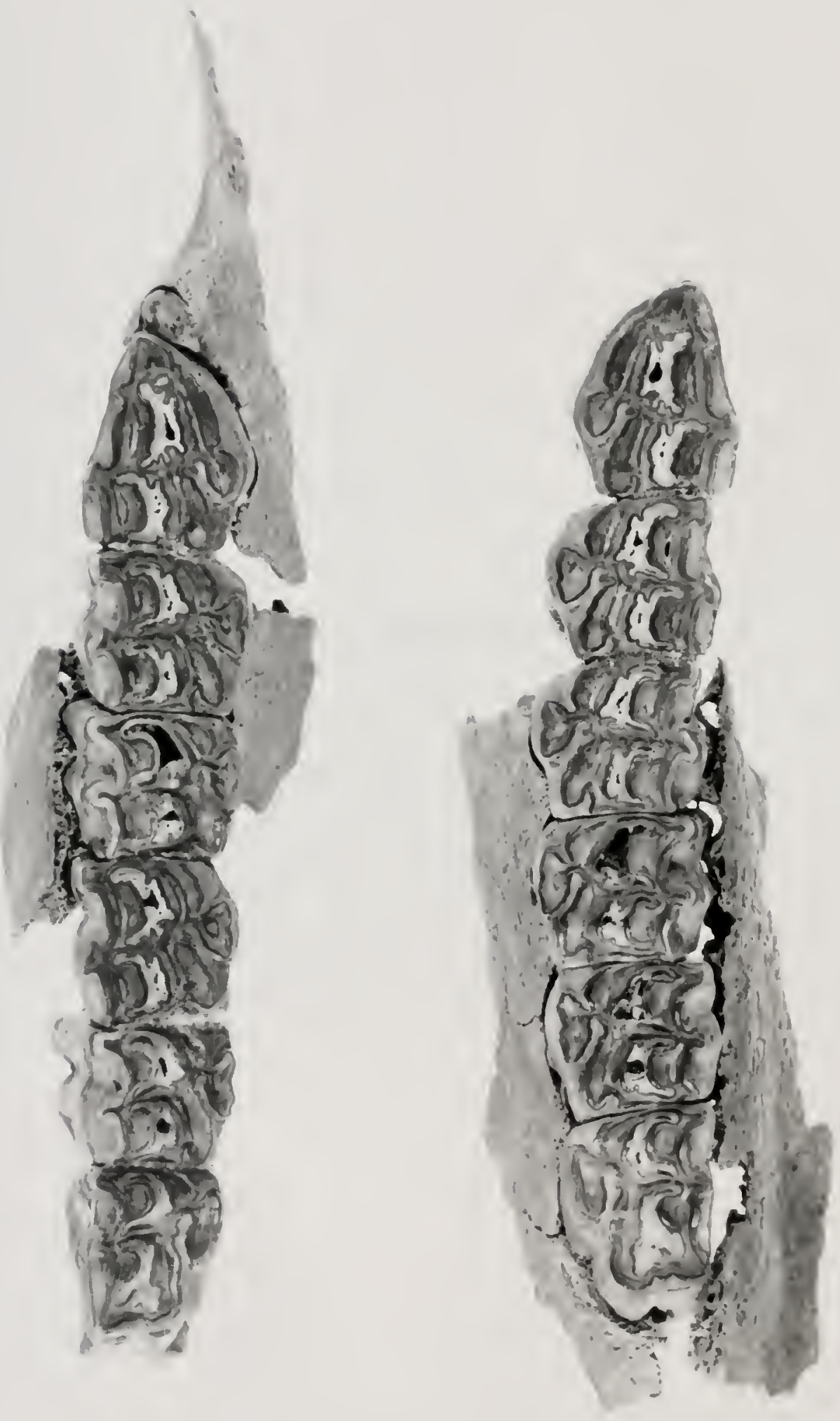
Measurements (in $\mathrm{mm}$ ) of the Upper Dentition of Plesippus simplicidens From Hajle XVA

Jeft

Right

Length of tooth rowt

158

155

Length, ${ }^{3} I$

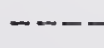

12.2

Width, $P_{1}$

Length, $\mathrm{p}_{2}$

Width, $\mathrm{P}_{2}$

Length, $\mathrm{I}_{3}$

width, $\mathrm{P}_{3}$

Length: $]_{4}$

Width, ${ }_{4}$

Length, $M_{I}$

width, ${ }^{\mathrm{M}} \mathrm{I}$

Length, $\mathrm{M}_{2}$

Width, $\mathrm{M}_{2}$

Lengih, ${ }_{3}$

Wiath, $\mathrm{I}_{3}$
6.4

32.9

32.8

24.7

24.6

24.1

2.4 .0

26.2

25,2

23.3

21.9

24.8

24.3

22.3

23.8

23.8

25.5

22.0

$22 \cdot 4$

22.6

23.9

28.8

33.2

23.0

35.3

All measurements were taken at the grinding surface; width measurements bo not include cement. *not including $P_{1}$ 
Mcasursinents (in rm) of flesippus simplicjacns postcranial Material From Haile XVA

Humerus

Transverse wicith, distal condyie Anteroposterior width, dista].

enc].

Radius

rotal length

Anteroposterior width, proximal end

Trarsverse width, proximal enả Anteroposterior :idith, distal condyle.

rransverse wiatin, äistal condyle

\section{Eenura}

\section{I'otal Lengith}

Transverse wicth, proximal end

Anteroposiericr wiath, proximal

$$
\text { end }
$$

J'ransverse width, distaj. condyle

Interoposterior width, djstál

$$
\text { end }
$$

\section{Metatarsal}

Anteroposterior sidth, proximal end

Transverse width, proximal end

Calcaneun

Total iongih

Jateral vidth

\section{Astragalus}

Total iength

Latojia]. rictll

Pyoximal Phalanx

gotal jengith

Wjath, Juckimai artjcuiar

surface

Wiuith, disial cal? $\begin{array}{lll}3 & \mathrm{X} & \mathrm{O}\end{array}$

$3 \quad 70.1 \quad 69.7-70.5$

$3 \quad 80.7 \quad 77.0-34.0$

1316.0

$1 \quad 77.6$

136.3

137.4

$1 \quad 57.9$

$\begin{array}{lll}1 & 368.5 & \ldots \ldots \\ 1 & 114.0 & \ldots \\ 1 & 88.5 & 84.0-39.7 \\ 4 & 87.2 & 114.0 \ldots 19.0\end{array}$

$2 \quad 41.2$

$39.6-42.8$

248.5

$48.2-48.8$

$\begin{array}{ccc}3 & 107.7 & 103.0-110.0 \\ 3 & 42.0 & 43.2-46.5\end{array}$

$258.0 \quad 57.0-58.9$

$2 \quad 58.8 \quad 57.7-59.8$

$3 \quad 73.5 \quad 76.5-8.1 .2$

$2.43 .7 \quad 42.8-44.5$

$4 \quad 36.1 \quad 33.7-38.5$ 
Table 16 (continued)

\section{Niediaj phalanx}

Total length

Width, proximal articular surface

IN

$\overline{\mathrm{x}}$

O.R.

$6 \quad 45.5 \quad 44.1-47.4$

$6 \quad 40.7 \quad 39.1-43.2$

$640.9 \quad 33.8-42.8$

ungual Phalanx

Total length.

$5 \quad 54.4 \quad 50.6-58.8$

hidth, proximal articular surface

$63 \varepsilon .5 \quad 34.1-43.3$




\section{Eguus (Asinus) sp.}

Material: UF 1.7750, upper cheek tooth; U1 17483, lower molar; Ul 17482, $M_{3}$; UF 1.7551, left humerus; UF 17552, astragalus; UF 17553, proximal phalanx; UF 17554, medial plialanx; UF 17555, ungual. phalanx.

The three tecth listed above do not agree morphologically with those of Plesippus. Regarding the upper tooth, the fossettes are much more complicated than in plesippus. The lower teeth are also quite distinct from those of plesippus Figured by Gazin (1936), Hibbard (1941), and McGrew (1944). In all the lower teeth figured by the above authors, the median valley enters the commissure. This is not the case with the Haile XVA specimens. Ir these, the median valley approaches the cominissure but does not enter it. In tiide respect, the Haile XVA specimens resemble Equus fraternus, a PJeistocere ass.

Several postcranial elements in the Heile XVA fauna also suggest the presence of an ass. These are much smaliex than specimens attributed to $\mathrm{P}$ - simplicidens. Hibbarci (1956) has reported the presence of an ass in the Meade County famna, in Meade Comty, Kansas. The referred specimen was a medial phalanx. The Haile XVA medial phalanx agrees very alusely with jegard to size (Table 17). 
Measurements (in mm) of Ecuus (Asinus) sp. Cranial and Postcranial Material From Haile XVA

Upper Cheek Tooth

Anteroposterior distance

iransverse distance

25.4

23.4

$\mathrm{M}_{3}$

Anteroposterior distance

Transverse distance

UF $17482 \mathrm{a}$ UF $17482 \mathrm{~T}$

-..- 28.7

$11.2 \quad 10.7$

Humerus

Total length

Transverse width, anterior end

255.0

$88 \%$

68. ]

Lateral width, distal condyles

46.9

Astragalus

Total length

50.4

Greatest wi.dth

50.0

Proxinal phälanx

Total length

60.6

wiath, proximal end

34.8

width, distal end

30.5

Medial Phalanx

Total length

Wiath, proximal articular surface

40.0

38.1

width, distal end

Unguai phalanx

Total lerigtr:

45.7

width, proximal articular surface

33.1

*estimated 
Family Tapiridae

Tapirus sp. Brisson $i 762$

Material: UF 17468, partial crown of a cheek tooth.

since only one genus of tapirs is known from postHemplifilian deposits of North America, it scents reasonable to ascribe this specimen to Tapirus. The material only serves to record the presence of this genus in the fauna. The only other 3 lancan record of this genus is the santa re I fauna (Webo, in press a).

$$
\begin{aligned}
& \text { Order Artiodactyla } \\
& \text { Family Trayassuidae } \\
& \text { Mylohyus floridanus Kinsey (in press) }
\end{aligned}
$$

Material: UF 18002, left and right mandibular ranj. arid luper left canine (holotype).

This species has recentiy been described by Kinsey (in press) based upon the material from Haile XVA. It represcits one of the few Blincan records for this genus. The material. is figured (Figures 18 and 19) and the diagnosis is included hexe in order to complete the siudy of the fauma. Measure-ments of the hoivtype are presented in Table 18.

Close to mylolyzis nasutus in size and clongation of the snout. Larger and more robust than Mylohyus fossilis and lacking extreme constriction of the symplyysis diagnostic of that species (tundeljus, i.960). Pre- and post-canine diastema longer than $i$ in oiner species of Mrlohvus. Symphysis mech more slender than in prosthcopos. Cormoid process triangular with straight, rot conval, artesior margin. 
Figure 18

Mylohyus floridanus Mandibular Ramus UF i8002, Haile XVA

X.89 (Iinear) 


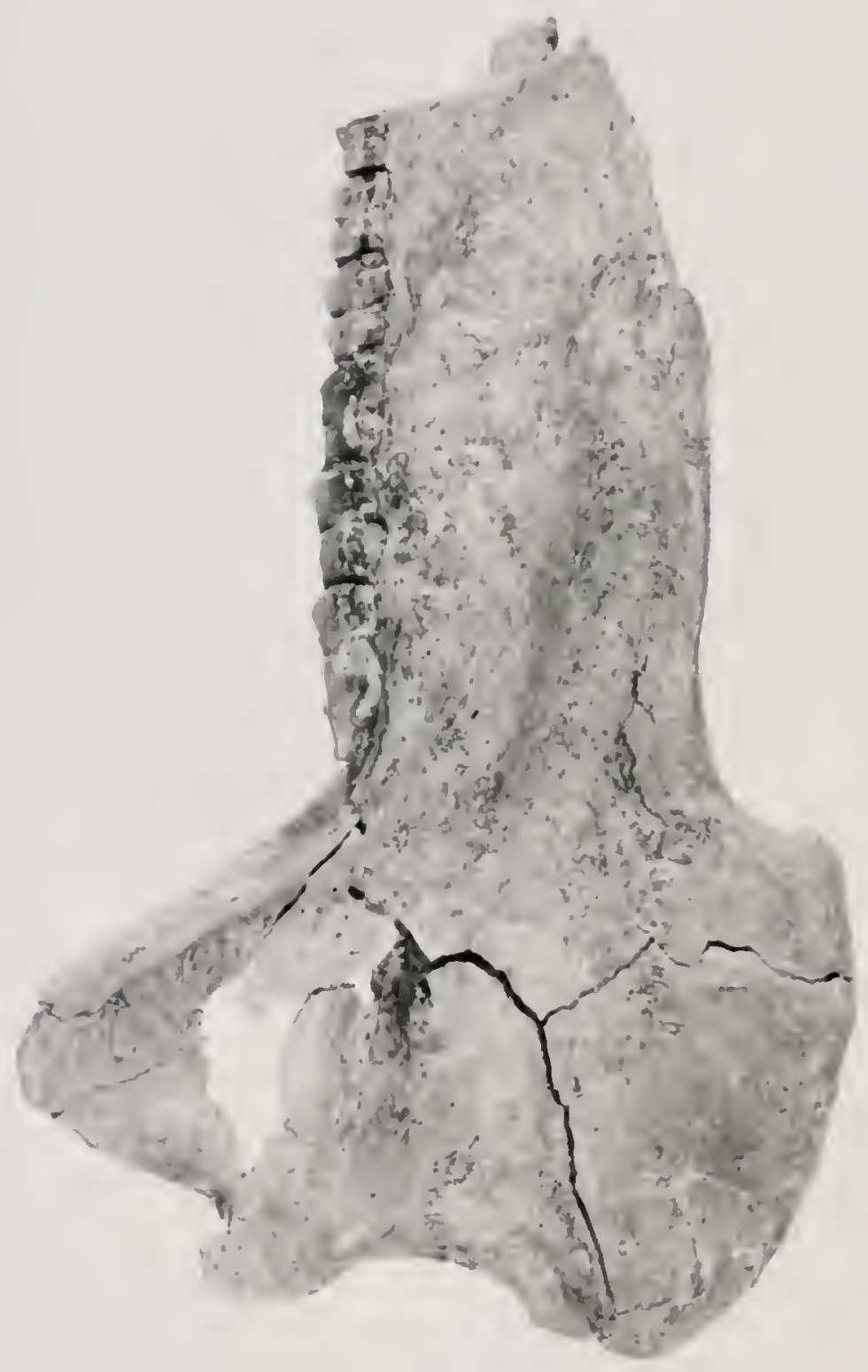


Figure is

Mylohyus floridanus Mandibular Symphysis

UF 18002, Haile XVA

X.89 (1inear) 


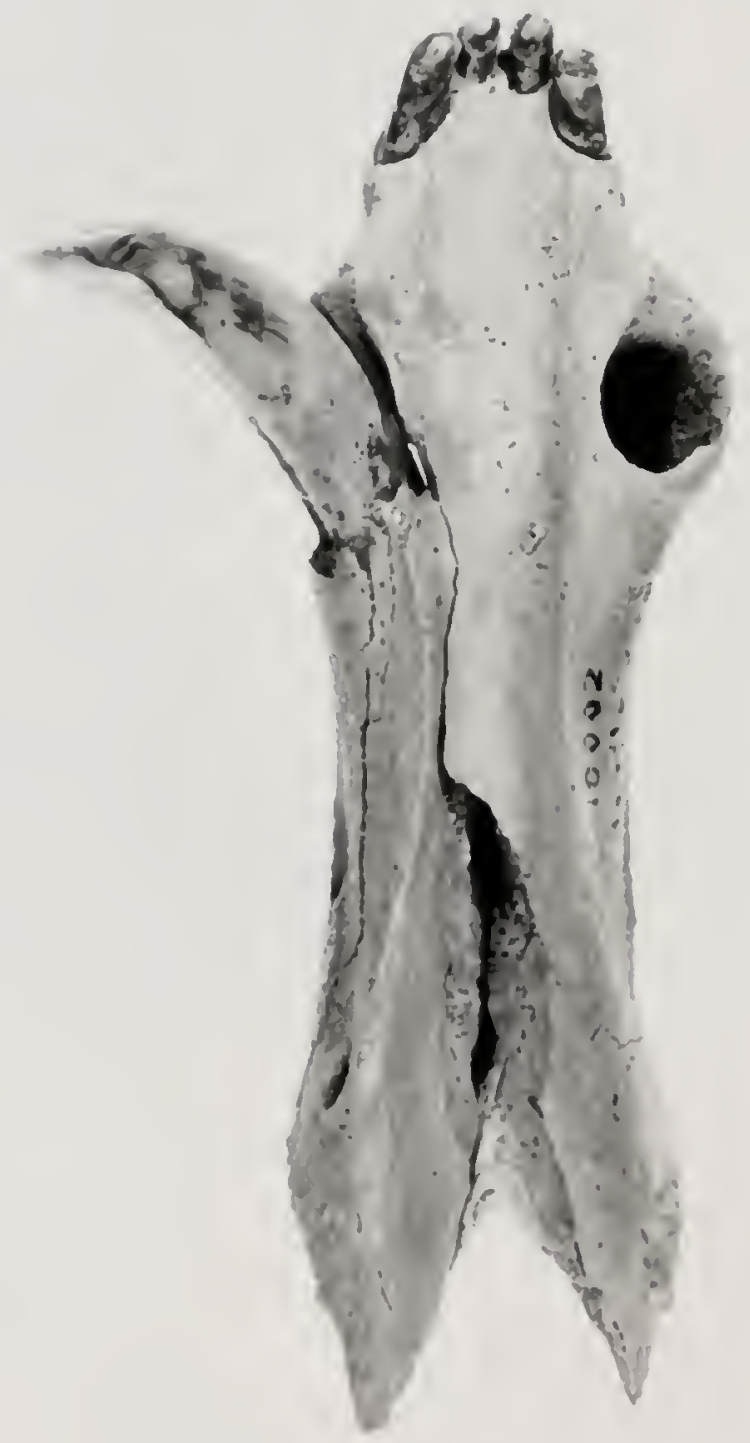


Measurements (in min) of the Dentition of Mylohyus floridanus*

Length, upper canine width, upper cainine Jength, lower canine Width, lower canine Length, $P_{2}$ Anterior width, $\mathrm{P}_{2}$ Posterior Wicith, $\mathrm{P}_{2}$ Lengith: $\mathrm{P}_{3}$ Anterior vidth, $P_{3}$ Posterior widih, $\mathrm{P}_{3}$ Lengtli, $\mathrm{P}_{4}$. Anterior width, $\mathrm{P}_{4}$ Posterior width, $\mathrm{P}_{4}$ Jength, $\mathrm{M}_{1}$ Anterior widtin, $M_{I}$ Posterior width, $\bar{M}_{1}$ Length, $\mathrm{M}_{2}$

Anterior width, $\mathrm{M}_{2}$

Posterior width, $\mathrm{M}_{2}$.

Jength, $\mathrm{M}_{3}$

Anterior width, $\mathrm{M}_{3}$ Posterior width, $\mathrm{M}_{3}$ Jength, premolars

Lengtis; molats

I.ength, molar-premolar series

Post-canine äiastema

Fre-canine diastema

Depth of jaw at $\mathrm{MI}_{1}$

Thickness of jaw at $\mathrm{M}_{1}$

hicith, jaw at canines

IVidth between canine alveoli

Least width, symphysis

Jength, articular condyles to anterior encl of: symphysis

\begin{tabular}{|c|c|}
\hline Ieft & Right \\
\hline 15.1 & $-\cdots$ \\
\hline 11.1 & ...... \\
\hline ]. 4.0 & \\
\hline 10.6 & $\cdots--$ \\
\hline 8.5 & $\ldots$ \\
\hline 4.9 & \\
\hline 5.1 & $\ldots \ldots$ \\
\hline 12.0 & \\
\hline 9.0 & \\
\hline 9.1 & $--\ldots$ \\
\hline 13.0 & \\
\hline 10.6 & \\
\hline 12.6 & \\
\hline 13.2 & 13.5 \\
\hline 12.6 & 12.8 \\
\hline 12.8 & 12.7 \\
\hline 15.2 & 15.5 \\
\hline 14.0 & 14.1 \\
\hline 13.9 & 14.1 \\
\hline 21.1 & 21.0 \\
\hline 13.1 & 13.1 \\
\hline 1$] .8$ & 1.1 .9 \\
\hline 33.1 & -..... \\
\hline 49.9 & 50.3 \\
\hline 83.0 & $\ldots \ldots$ \\
\hline 80.0 & $\ldots \ldots$ \\
\hline 14.0 & 13.0 \\
\hline 4. 1.2 & 41.0 \\
\hline 21.2 & 2.1 .1 \\
\hline 41.2 & $\ldots-\ldots$ \\
\hline 17.6 & ....- \\
\hline 26.4 & $\ldots$ \\
\hline 73.0 & \\
\hline
\end{tabular}

* measurements aftej Kinsey (in press) 
Total length of the $\mathrm{p}^{-1 \cdot 1_{3}}$ scries less thin in other Mylohyus, both absolutely and relative to the overall length of the jaw. $M_{1}$ and $M_{2}$ relatively shorter than in other Mylohyus except $M$. exot jeus (USNM 8876). Anteroposterior diameter of $\tau^{r}$ greater than in all. other Mylohyus, both absolutely and relative to the chock teeth serics. Width of C greater relative to width of $\mathrm{P}_{2}$ anci ${ }^{M_{1}}$ than in other Mylohyus. (Kinsey, in press)

It is interesting that Mylohyus does not occur in the other Blancān faunas of Floridà. Such a large fauna äs Santa Fe I, For example, should contain some remains of this genus if it were present in the axca in any great rumbers. That it was scarce in Florida in pre-Rancholabrean time is suggested by the coleman. IIA fauna in which platygonus cutnumbexs Mylohyus eleven to one. platygonus is plescnt ir: the Santa Fe I fauna. The occurrence of differant peccary genera in the Haile XVA and Santa Fe I faunas may sugyost an ecological difference between the two. This possibijily will be discussed in the paleoccology section.

Family Camelidae

Hemiauchenia cf macrocophal cope 1893

Matejiall: UF 10900, partial s3ull; Ui lo894, ? cexvicai vertobrae; UF 10899, phalanges (3 modial, ] ungual).

The liaile XVA skull (UH 10900) consisus of the joildate with upper dentitjon (F'jure 20) and pert of the cranium. The cyanial Eragnent incindos parts oi lle parietal, left

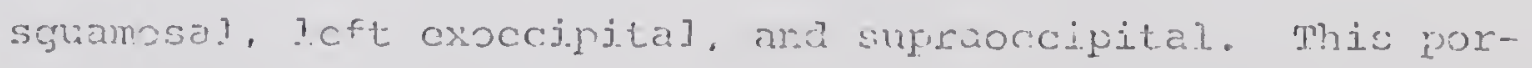


Figure 20

Hemiauchenia cf macrocephala upper Dentition UF 10900, Haile XVA X.93 (Iinear) 


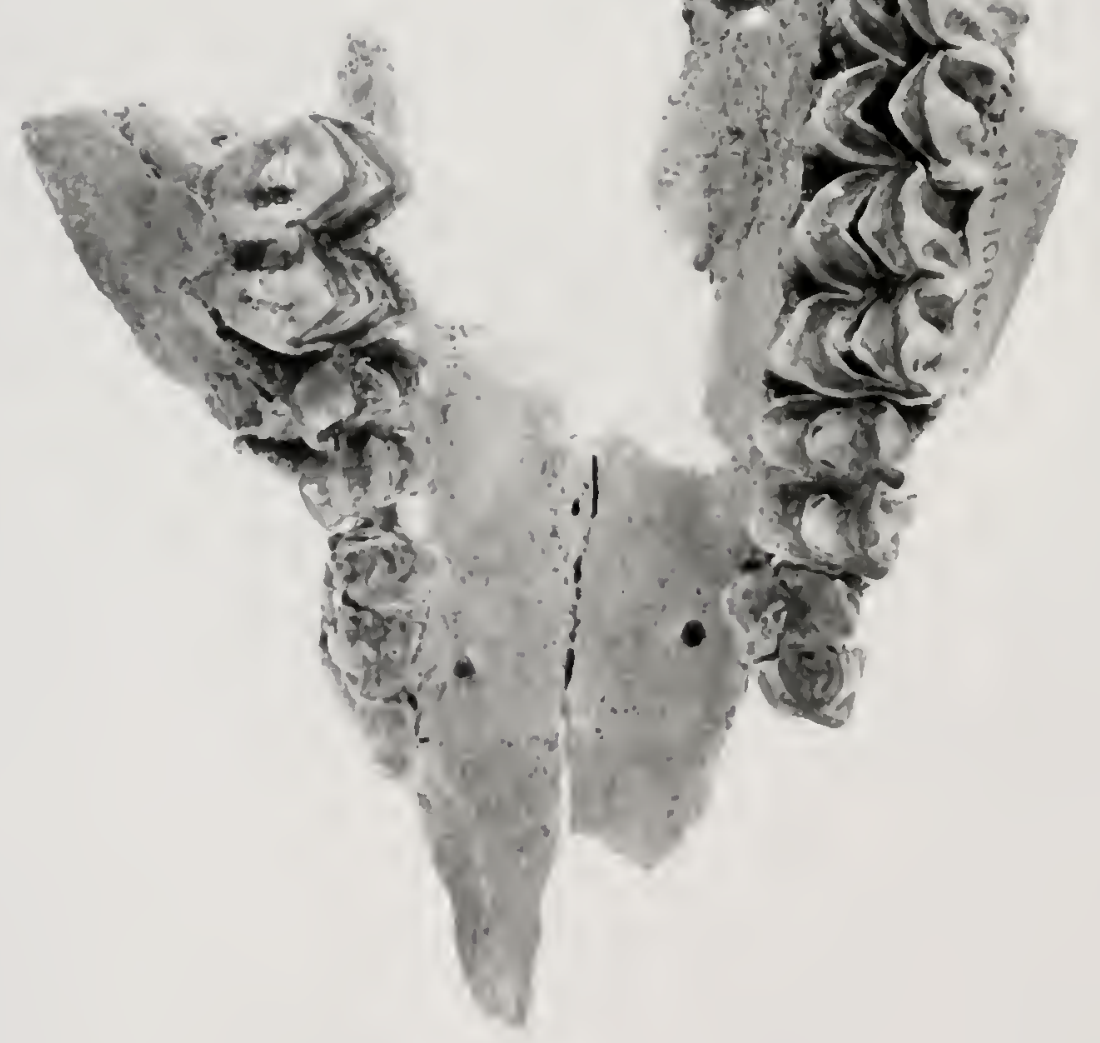


tion of the sloull, particularly the extemal auditory meatus and the subsquamosal foramina, acrees very closely with the type material for Tanupolama figured by stock (1928). The Haile XVA specimen represents a juvenile individual. The left $\mathrm{DP}^{2}$ is present as are the left and right $\mathrm{DP} \mathrm{P}^{3}$ and $\mathrm{DP} \mathrm{P}^{4}$. Left and right $\mathrm{P}^{3}$ and $\mathrm{P}^{4}$ are present but unerupted. The complete right molar series is prescrit while the left is represented by only $Y^{3}$.

The Haile XVA specimen is a small 1 lama referrable to what most authors have called Tanupolama winich is now part.ly inclucied in Hemialucinenia in a recent: revision (webb, in press b). In this revision (webb, in press b) three Nortn American species are recognized: H. b]ancoensj.s, H. seyman.ensis, and H. macrocephala. Hemiaudlenia blancoensis is large and has a relatively narrow $\mathrm{P}_{4}$. Hemiaucheria seyinurensis is about as large as H. blancoensis and differs from it in the nature of the $\mathrm{P}_{4}$ (Hibbard and Dalquest. 1962). Memiauchenia macrocephala is the smallest of the North American species and has a relatively wider ${ }^{{ }_{4}} \cdot$ me Haile XVM specimen lacks the $\underline{p}_{4}$, but the specimen is guite small (Table 19) and tonizive species allocation is based on size.

The occurrence of 1 . macrccephala in the Haile XVA faund marlis its earliest record anymere. That this species nas a $20 n 9$ cortiruous history in Florida is indicetea by its 
Measuroments (in unm) of the Upper Dentition of Iemiauchenia cf macroccphala From Haile XVA

Length, Jp/ ${ }^{2}$

Widin, $\mathrm{DP}^{2}$

length, DP $^{3}$

Anterior width, $\mathrm{DP}^{3}$

Fosterior width, $D p^{3}$

Length, jop 4

Anterior width, $\mathrm{DP}^{4}$

Posterior width, $\mathrm{DP}^{4}$

Jiength, $\mathrm{p}^{3}$

width, $\mathrm{P}^{3}$

Length, $\mathrm{p}^{4}$

wj.dth, $\mathrm{P}^{4}$

Length, $\mathrm{M}^{\mathrm{I}}$

Anterior width, MI

Posterior, width, $\mathrm{M}^{l}$

Length, $M^{2}$

Anterior widih, $\mathrm{N}^{2}$

Posterior width, $\mathrm{M}^{2}$

Length, $\mathrm{M}^{3}$

Anterios width, $\mathrm{M}^{3}$

Posterios width, $\mathrm{M}^{3}$

Length of deciduous premolar series

Length of molax series

Lengtis of tooth low functional at time of denise

Length of permancint tooth row

palatal width ai $\mathrm{DP}^{3}$

Palatal widir at. $\mathrm{DP}^{4}$

palatal width at $M^{1}$

\begin{tabular}{|c|c|}
\hline Left & Right \\
\hline 10.8 & --- \\
\hline 5.8 & $\cdots--$ \\
\hline 19.7 & 19.2 \\
\hline $11.5^{1}$ & 12.4 \\
\hline--- & 17.3 \\
\hline 19.6 & 18.8 \\
\hline 17.7 & 17.8 \\
\hline 19.2 & $1.9 .1_{2}$ \\
\hline$---\cdot$ & $16.5^{2}$ \\
\hline---- & 9.9 \\
\hline--- & $18.8^{2}$ \\
\hline 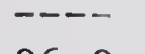 & 15.2 \\
\hline 26.2 & 25.7 \\
\hline 20.2 & 2.1 .2 \\
\hline 19.8 & 2.0 .4 \\
\hline---- & $22 . ?$ \\
\hline$--\cdots$ & 23.2 \\
\hline--- & 19.7 \\
\hline---- & 26.6 \\
\hline$-\cdots-$ & 11.2 \\
\hline--- & 19.1 \\
\hline 50.1 & ......... \\
\hline---- & 75.0 \\
\hline
\end{tabular}

$125^{1}$

1. $10^{1}$

34.5

37.5

47.5

Iestimated

2unerupted 
presence in the Irvingtonian Inglis IA faune (Webb, in

press a). Hemiauchenia blancoensis cccurs in the santa Fe I fauna (Webb, in press b) possibly inaicating ecological differences.

This genus was widespread in the Blancan, being present in most North American faunas of this age. It also occurred in the Argentinian Chapadmalaian Fauna (Kraglievidhia, 1946). Fanily Cervidae

odocoileus virginianus zimnerman

Material: UF 10885, 6 partial upper dentitions; UF 17431. right mandible with $\mathrm{P}_{2}, \mathrm{DP}_{4}, \mathrm{M}_{2}, \mathrm{M}_{3}$; UP 17478 , left $\mathrm{P}_{1}$, UF 17477, right $M_{3}$; UF 10883, 19 cervical vertebrae; UF 10889, 25 thoracic vertebrae; UF I0884, 35 Iumbar vertebrae; UE 10891, 3 left humeri; UF 10893, right humerus; UF 174.79. 3 metacarpals (2 left, 1 right); UF 10887, metatarsal; UF 17480, left astragalus; UF 10886, 3 podials; UF 10888, 15 phalanges.

The genus odocoilens is recognized in many of the Blancan faunas of North America. In most cases, however, the material has been scarce and species allocation has not been possible.

Tha defiritions of closely related species (and genera) of deer are very similar, and the taxonomic problom is compouncice by the iarge amount of indiviciual variation in these 
forms. The nature of the ${ }^{2}{ }_{4}$ is considered impertant in decr taxonomiy at the generjic or sulggenerjc level; unfortunstcly, this tooth is also the most vuriable. In Simpson's (1928) discussion of Blastncerus extrancolis, he pointed out that specimens of odocnileus studied approached Blastocerus in character, and some Recent Blastocerus material diverged from his specimen toward odocoileus. The subgenus procoileus (Frick, 1937) is basco primarily on the characters of the $P_{4}$. An examination of a large sample of odocoileus teeth from the Santa Fe I. fauna showed individual. variation approaching the characters of Blastocerus, procoileus, and even cranioccrus. A similar, though not as arastic, example o: individual variation observed in a sample of odocoilcus teeth from scvoral lates: Plcistocene and Recent sites in Floridi. It appears as though $\mathrm{P}_{4}$ morpiology is not reliable for taxonomic studies.

One $\mathrm{P}_{4}$ is preserved in the Haile XVA material. Only the labial portion of the tooth is prescrved, and it shows little wear. The portion present, however, compares favorably with most specimens of o. virginianus observed. The sholpe and rolitive size of antlers are other characters usnd in decr taxonomy (Frick, 1937), Unfortunately, no ant]er matcial. is prosent in Hajle XVA. 
of fossil deer. The Haile XVA decr are relatively small. This is not considered taronomically significant, howcver, as a size comparison of certain postcranial elements from various stages of the Pleistocene (Table 20) shows random size Eluctuations. Evidentlÿ, odocoileus exhibits no such size trend throughuit the Pleistocene as was shown for the edentates. The size variations seen are probably a reilection of ecolngical conditions. Harlow and Jones (1955) show that the size of Recent deer fluctuates significantiy from habitat to habitat within the state of Florido.

Finally: an element by element comparisor of the Jaile XVA doer material with specimens of o. virginianus fyor othex Florjac pleistocene sites, and with Recent soeaimens, shows no conspicuous differerces. It is considared ther, that: the Haile XVh cervid represents odocoileus virgiriarus. 


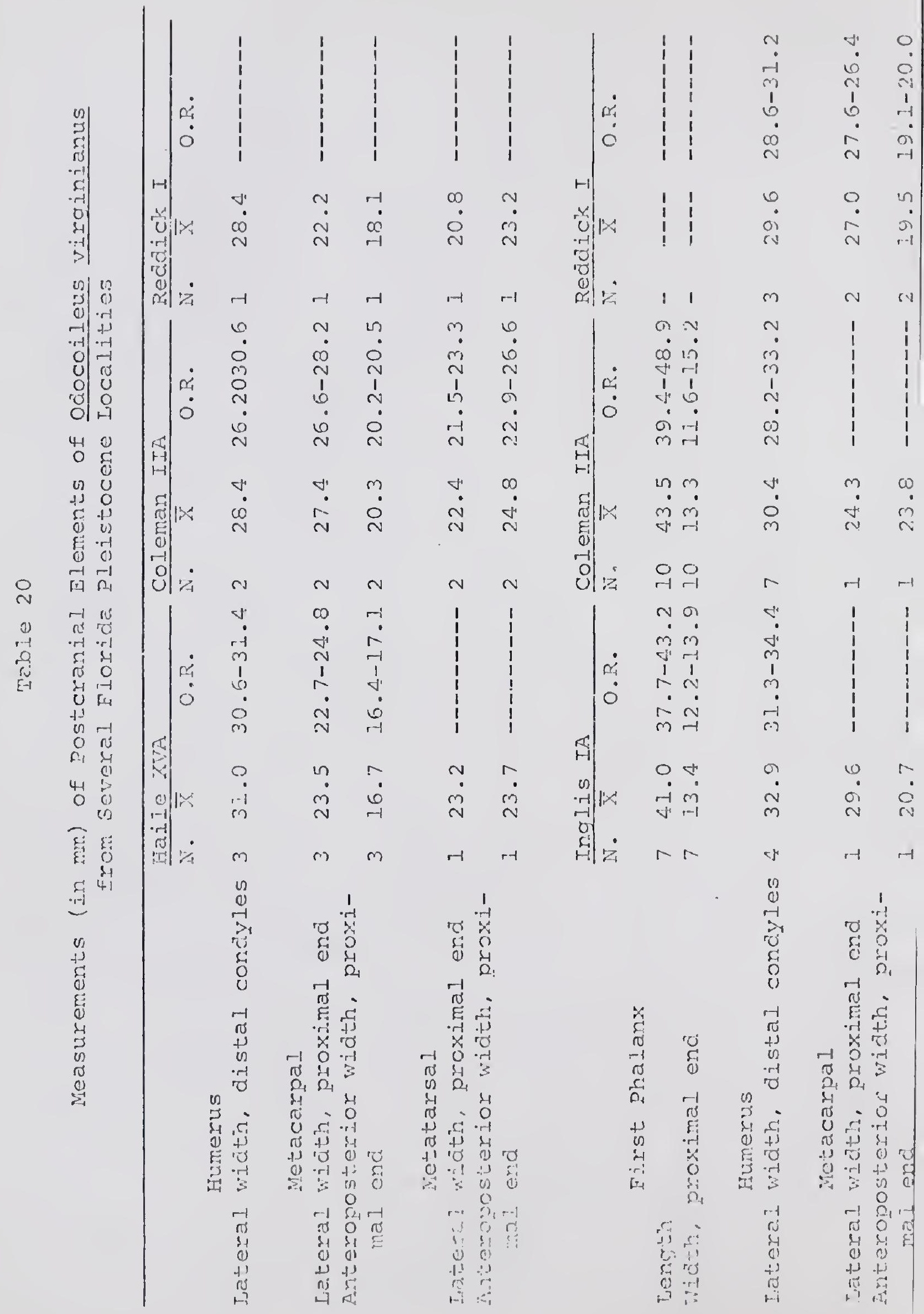




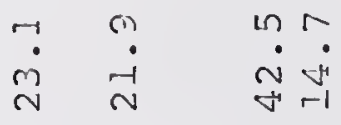

ri Hi

$\infty \infty \infty$

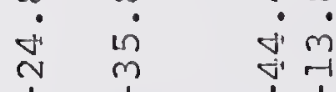

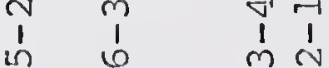

i $\dot{0} \dot{0}$

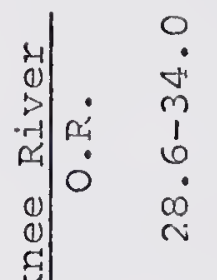

In $\quad$ In

$\infty 0$

ก

मिं

$\begin{array}{cccc}1 & 1 & 1 & 1 \\ 1 & 1 & 0 & 1\end{array}$

$\begin{array}{rr}1 & 1 \\ -1 & 1\end{array}$

$\ddot{\sim} \stackrel{-r}{\sim} \stackrel{\sim}{N}$

m $:-1$

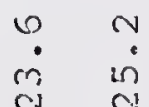

$\nabla 0$

(i)

$\begin{array}{llll}\pi & 0 & n \\ i & 0 & n & \text { in } \\ i & n & N\end{array}$

in $N$

+

rr r-1

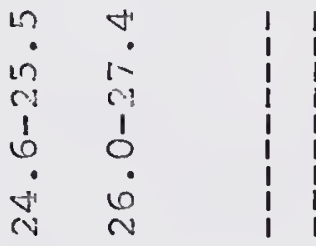

บ I ?

ये

$m m r$

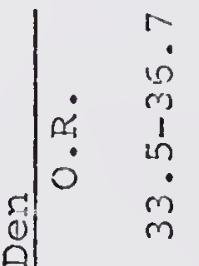

i m i

m

1 in

in

$\begin{array}{cc}n & 1 \\ i & 1 \\ 1 & 1\end{array}$

ì

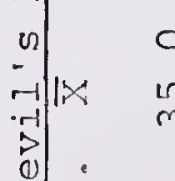

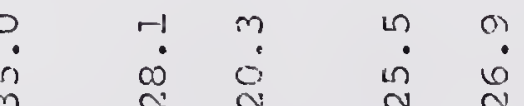

$\begin{array}{lllll}0 & m & m & n & 0\end{array}$

ấ

$\begin{array}{llll}H & r & r-1 & r-1 \\ & H & r\end{array}$

$-i \dot{i}$

स. $m$

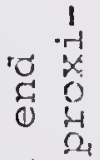

त)

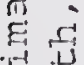

:

$\rightarrow 00$

of 1

दू

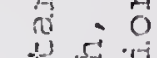

कs

?1

(i) $\rightarrow+15$

302 in 0 in

ñ

is $i_{i=1}$

() (1)

+

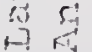
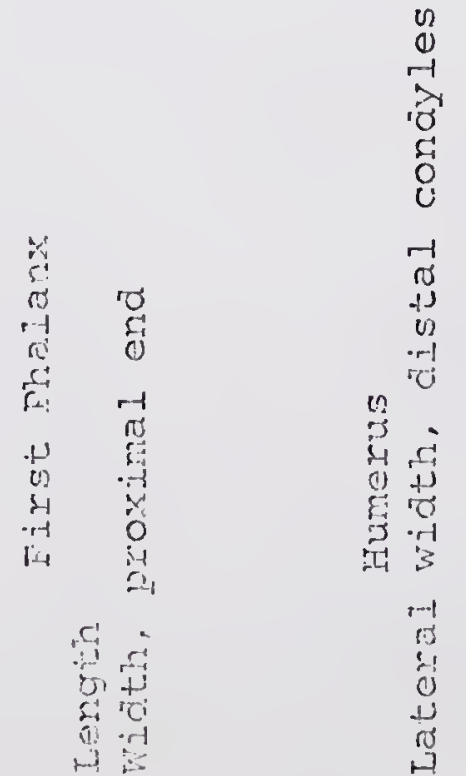

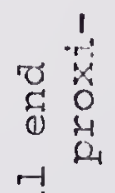

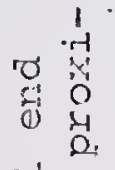

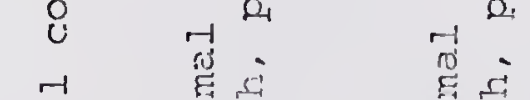

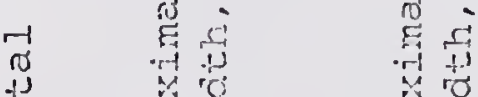

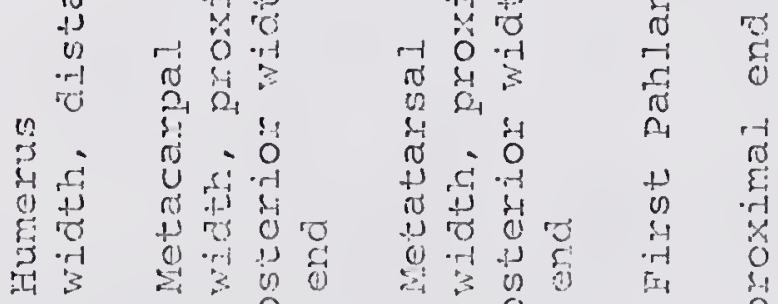

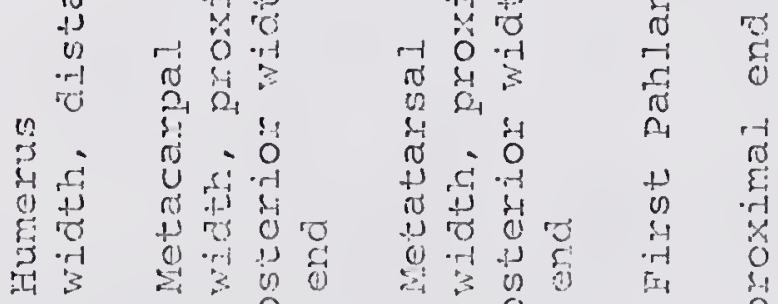

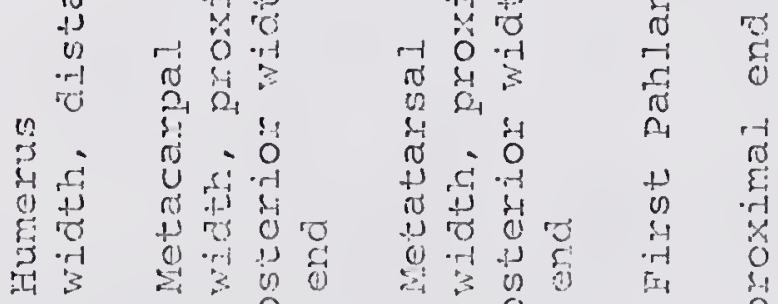

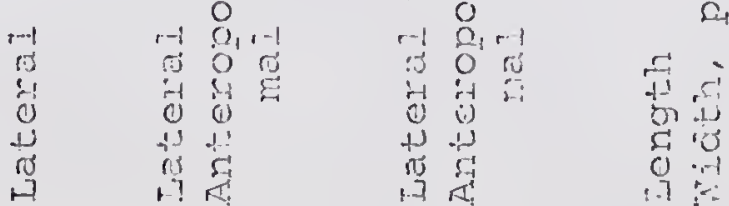

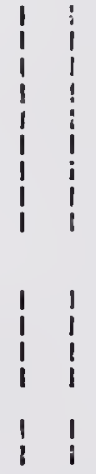




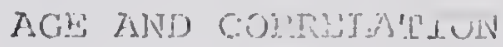

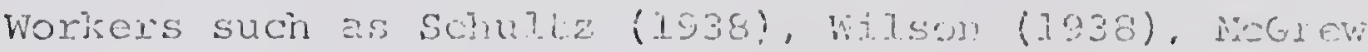
(1944), and others have Jorg recogedized thet the istarem faunas of North Anerica car 30 jocrijfick by tin prosence

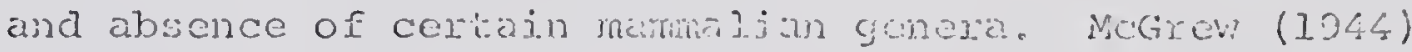
summarized thesc as foljois:

(1.) the absence of iypicaliy Eliocene cienex: (2) the presence of charactoristical.y nicio and late Fleistocene genera; (3) the presence of certain genera that survived from the Iemplinian but which dict not out Ive the Blancan; (4) hle presence of certain gcrisis that wexe limited to the shiscari anc? (5) the ahsence of certaju gencra that dici not make theis appearance until. after the close of the intarabn.

In the folluwing section, each of tire above critroxia will be examined with regard to the liajle xtra fama.

There are no typically ivouth irwicen! pljocenc gonern rep-

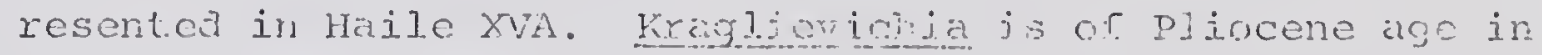
South America but j.s B]ancian or iater in Noris Amorica. yt should be pointed out here, howsver, tinat negative evidence,

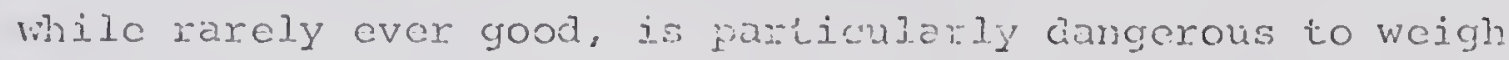
heavily in relition to the Haile XVX faund. The small number of tara and individuale yolnoly indicates that the

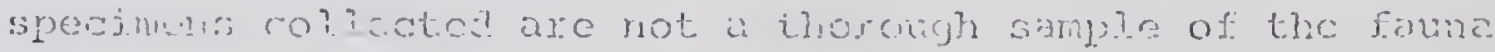
coxisting in thre ireal at that ine. 
(2) There are some characteristically midale and jate Pleistocene genera present in the fauna: odocoilevs. Mylohyus, Smilodon, and Sigmodon represent this elcment.

(3) Of the genera which survived the Hemphillian but: not the Blancan, only Nannippus is prosent for certain. rithe prosence in the fauna of a gomphotheriia may fit this category, but the lack of a definite generic allocation makes its inclusion here tenuous.

(4) There is only one representative of the genera which are totally restricted to the Blancan, the plesippus. The accurrence of Sigmodon hedius and Nannippus phlegon is critical, however, as these species are restricted to the Blancan。

(5) No gerus appearing after the close of the Blancan is present in raile XvA. This again is negative evicence, and the remarks previous ly made concerning this also apply here.

Wheir all the mammalian faunal evidence is considered (see Table 2l), particularly the presence of Nannipus, Plesippus, and sigmodon medjus, a Blancan age seems conclusive.

More refined correlation of the Hajie XVA Faund witi other North American biancan faunas (outside of Florida) leads to cifficulties resulting from geographic djstance and 
'lat).tc 21

lamnal. Comparisons of Hailc XVA and othrx Blancan Jocalitics

Hajle XNAA

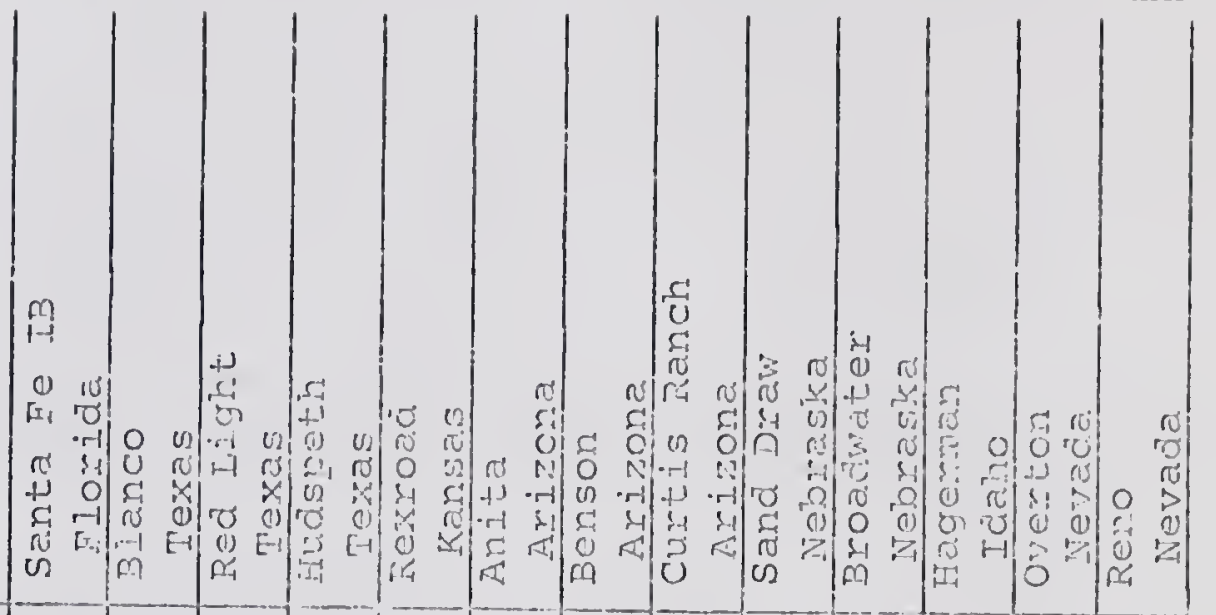

Cryptotis

Sical lopus:

Glossotherium

Dasypus

Kraglievichia

Sylvi]agus

Petauria

Costox

Sigmodon

Smilodon

Pteromura

Tapirus

Nannippus:

piesippus

pyebrys

ogocoileusis

Ioninuelising

x x y 背.

$x$

$+1-1$

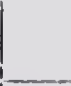
$+[\mathrm{x}$

\begin{tabular}{l|l|l|l|l|l}
$x$ & $x$ & $x$ & $x$ & $x$ \\
\hline
\end{tabular} $\mathrm{x}$

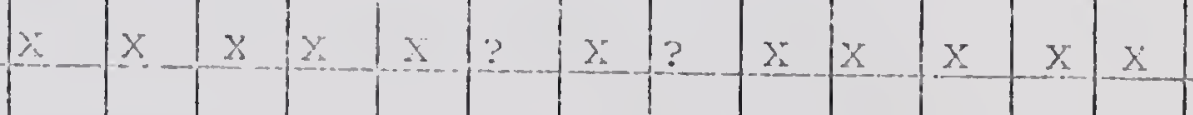

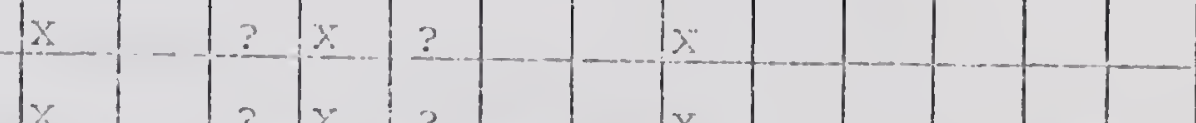


pable 21 (continuea)

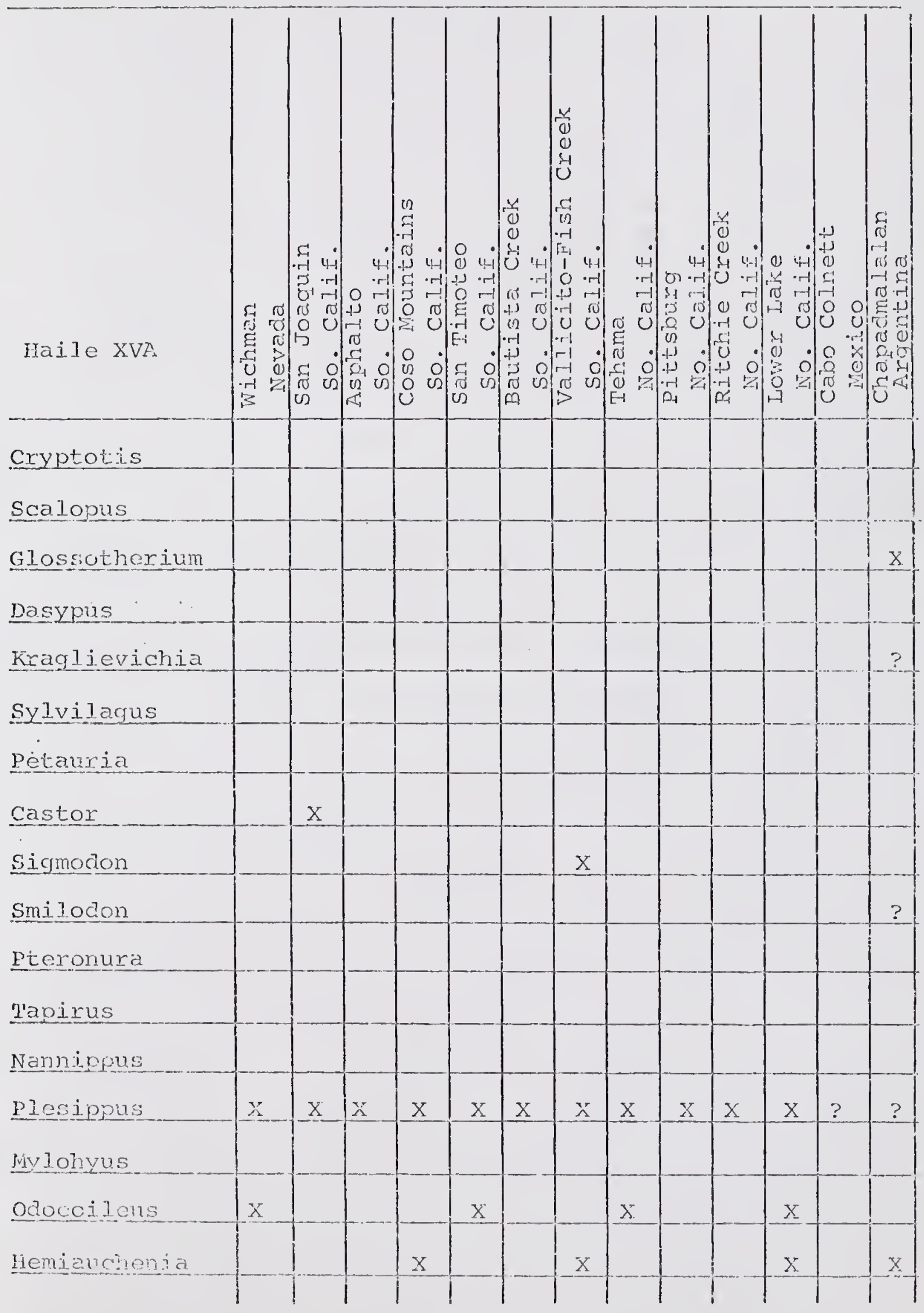


coloçicnl differences. Most Blancan fäunas are located in western North Mmerica, and no Blancan faunes outsiaje of Floj:icta are known from the Gulf coastal plain. Consecquentry. it is easy to see that the lack of a more detailea faunal comparison need not imply a great difererence in time. The absence or Kravlievichia and Dasypus from Blancan situs elsewhere in North Anerica is probably cue to the geographic difference and not a temporal one. Conversely, a closer corielation with other Blancan famas in Flojida (for example, Santa $\mathrm{FC}$ I) does not necessarily indicate precise equivalence in time. Althougl. close similarities exist botween the Haj.lc XVA and Santa Fe I famas, enough differences are present to indicate a difference in time. me Santa Fe I camel belongs to the typically Blancan species Iemiauchenia blancoensis while the fiaile XVA form mosi closely resembles 1 . macrocephala. This possibly inaicatas: a younger age for Haile XVA, as $\mathrm{H}$. macrocephala is the typical Irvinctonias and Rancholabrean form.

Thexe are certain forms found in the santa Fe I fauna which onc woule also expect to find at Haile XVA but does not. Notable among these is the typically Blancan dog Boroplagus. The absence of this form from the Haile XVA fauna probaty mei he attributed to sampling error. rihe abscnce er casiogoising and rivdrochocruss from Haile XVA is 
probably due to the same phenomenon. Other differences between the faunas of Haile XVA and Santa Fe I are most likely ccological1y induced. These are discussed in the next section.

Fmong the best represented animals in the Haile XVA fauna axe the edentates, a group of undoubted South Anerican origin. of the three genera at Haile XVA, only Glossotherium has been previously recogizized in Nortin American Blancan faunas, being present in the Blancan faunas of Texas and Nebraska (Table 2l). Dasypus has not been found so early elscwhere in North America. Kraglievichia has not been recognized at all in Norin America, although its probable descendant Chlamytherium (=Folmesina) has been found in Irvinçtonian and Rancloolabrear deposit.s.

This record of a major influx of edentates from south America is a fucther indication of the pliomleistocenc age of Haile XVA. The small chlamythere from Iaile XVA shows a remarkable resemblance to the species Kraglievichial paranesis rrom jate Pliocene deposits of South America. AIthough no authentic Chapadmalalan (early pleistocene) species is hnown, it probably lived in regions nore tropical than Argentina and probably also resembled the florida material. Forida and Argentina apparently represent the northern ard solithern Iimits of the range for this form, and it seems 
safe to conclude that the memises occupying the middie portion of the range were similar. The close rescmblance of the Ilaile XVA G]ossotherium to that from the Chapadmalal. also supports the correlation between the Haile XVA deposit and the Argenitine Chapadmalalan oposits.

Thj.s Blancan influx of edentates into Floxida muderIines previous correlation between the Biancar stage of North America and the Chapadnalalan stage of South America. That correlation previously has been based upon the appearance of mumerous Nearctic species in South Mmerica (Patterson and Pascual, 1968). Those Nearctic forms from Haile XVA which closely resemble elements of the Chapadmalalan fauna are Smilodon, Equus, and Hemiauchenia. The corbindtion of correlative Eaxa of both Nearctic anä Neotropical origin! makes the resemblance between the Blancan fauna of Florida and the Chapadinalalan fauna of Argentina extraordinariny strorig.

The presence in the Haile XVA fauna of shark vertebrae that are simijar in preservation to the other vertebratess (and therefcre probably not intrusive) indicates that the sed stood nearby cluring the time of deposition. Fven thongh sharks are partially able to tolcuate fresh water, tineir presence in latge chough mimers to become part of the fosidj falina suggonts that the sea was nearby. Buring the 
interglacial stages of the pJeistocene sea levels were high. Inland localities of higher elevation such as Hajle XVA (90 fect above present sea level) which were near the sea must represent interglacial deposits. This evidence, in combination with the Blancan age of the mammalian assemblage, indicates tinat the Haile XVA deposit represents the Aftonian Interglacial. 


\section{PALEOECOLOEY}

A complcte palcoecological study of an area j.s not possilole by exumining a small sample of its vertcbrates. That the Haj.le XVA fossil mammal assemblage is not a representative sample of the manmalian communty which once Iived in that region is shown by the relatively small number of inaividuals present and the lack of a significant variety of small mammal species.

The locality seems to represent an aguaitc locai situation such as à lake or a stream bed. This is irdjeated by the large amount of fish, amphibjan, and aquatic roptile remains recovered from the site. Anong the fish are three species of catfish as well as Amia, Centropomus, Lcpisostcus, anō a rost of other as yet unidentified species. These forms alc prescibly not found in sinksoles containing water, but live in oper ponds or straams. r'he varicus turtles which have boon collected at Haile XVA, including chryscmys platymarginata, poinyz, kinostcrnon, and Chalycira, also indicate an aqualic local crivironment. The box turt te perrapene is alsa roprosented in tie fauna but was probably trapped in 
the same manner as the terrestrial mamals. The Amphibia include both anurans and urodeles, and further suggests the aguatic situation as most of these forms rarely travel far fxom water. Ainong the birds present at Haile XVA are a duck, a heron, and a greise. A thorough sturly of the birds is presenty $y$ being conducted by Mr. Kenneth Campineli, a graduate student in zoology at the university of flocida. Although the non-mammalian fauna has not heen studied in detail, a preliminary analysis is enough to indicate samoliing of an open aquatic environment of deposition. The marnars divide readily into two ecological components, a smalier group of aquatic types and a larger group of terxestitij taxa. Castor, as is well known, inhabits mediuin to large: permanent bodies of flowing water. Pteronura inhabits streams from the Guianas to Argentina (Walker, 1960). Its surrounding habitat is probably secondary to its stream habitat as it lives in suitable rivers which flow throngh a variety of habitat types. Jhese mammals: thorefore, are ecologically allied with the turtles, fishes, and water birds, as primary inhabitants of the aquatic site. The ctiner marumals lived on land adjacent to the site of deposition.

Beforc consjdering the terrestrial community, let us Further consicor the aquatic situation. In attempting to 
interpret the aquatic cnvironment of doposition at Hailc $X Y \lambda$, the following possible situations are considerch:

(1) a cave containing a pond into which animals wandereci:

(2) a quicksand or mud mire adjacent to a slower moving portion of a stream which trapped animals as they came to dirink; (3) the spring-head of a river into which arimals fell. Thesc possibilities are discusser? holow:

(I) The cave pond hypothesis seems unlikely for two reasons. First, the very coarse naiure of the principle fossiliferous horizons suggests more rapid transportation of sediments than would occurs in a cave pond. Sccond, ith abundance of inhabitents that prefer open moving water seems to precluae the cave pond hypothesis.

(2) A quicksand or mud trap would tend to select for large: anjmals as the smaller ores would be less like?y to become bogged down. However, it would not be expected to ¿ large and varied aquatic fauna, nor would it normally contain such coarse sediments as those or the Haile xVA aeposit.

(3) The spring-hoad hypothesis appcass quite appealing. It coulc explain the accumulation of a great number of large torrestrial animals and the relative scarcity of smaller terrestrial ones. J'lue presence of a row acnse clements of signodon, Sen?ogus: Cyypioits, aud petaugja would have to 
be ascribed to fortuitous burial. The only other smaller matmals in the fauna are Castor and pteronura, and because these are normally aquatic animals anvway, they should occur throughout the stream. All the rest of the manmals in the Haile YVA fauna are liage terrestrial forms, the bypes one would expect to we trapped by the treaclierous slopes and abrupt limestone ledges which often occur arowid Elorida springs.

Nest. we may consider the nature of the terxestrial commurity adjacent to the spring-head site of depositior. The terrestrial animals sampled consist of a fen small mammals and a greater variety of large mammals.

The presence of wide ranging forms such as Hemiaunhend, Plesippus, Nannippus, and Smilodon and eurytopic forms such as odocoileus, Cryptotis, Scalopus, and Sylvilacus do not reveal much about the paleocology of the area. These forms are present in most of the North American Blaroin faunas and probably ranged througin many hajitats.

Several taxa in the Haile XVA Eauna indicate the preserice of a forest community adjacent to the site of deposition. The presence of Mylohyus lends critical support to this interpretation. Iundelius (1960) revicws the evidence that strongly injlicates Mylohyus as a foresi aweller. He also incluaes Castor, Iapirus, and glaucomys (among others) 
as forcst forms. Both castor: and Iapixus are present in the Haile XVA fauna, ind the flying squirrel petauria (like

Glaucomys) cortainly indicates a forcst cnvironment. Glossotheriun. also presumably favored forcsted areas.

Dasypus and Kradlievichia were probably restricted in Iorth Amexica to the Gulf Coastal plain by their need for moderate to warm temperatures and high rainfall. rlis ¿s indjcated by their absence from all other North Imerican Blancan faunas. In South America, Kraglicvichia seems to have been largely restricted to the northern tropical por.tion of the continent. These edentates suggest a tropicai or subtropical climate for central Florida during the 2 ritonian.

In summary, tlie geologic and paj.contologic evidence seems to indicate that the Haile XVA site lay at the spinghead of a toastal strcam which flowed through a tropical or subtropjcal forest. 


\section{ZOUGEOGRA DHY}

The Haile XVA fauna is the first Gulr coastal plain Blancan fauna to be described. Apparently its unusual faunal assemblage compared to other Blancan faunas is a. reflection of its location. All other described North American Blancan faunas probably represent upland areas which were peripheral to the subtropical corridor through which most of the South Anerican emigrants passed.

Among the edentates, only Glossotherium was not restricted to the tropical portion of North America. This is indicated by its presence in the Blanco (Texas) and Lroalwater (Nebraska) faunas. In South America this genus was probably distributed throughout the continent as the presence of $\mathrm{G}$. chapadmalensis in Argentina would indicate. They were no doubt also present in the more equatorial regions of South America during Plio-Pleistocene time although fossil deposits of corresponding age in these areas have not yet been found. 'riroughout the later pleistocene this genus was wichespread on both continents.

Ir cortrast to Glossotherium, Kraglievichia was 
apparcntly restricterl to the tropical or subtropical. portions of North Ancrica during Blanuan time. Their tota] absence from all other North American plancan faumas outside Florida bears this out. The presence of these forms in Fliocene deposits of Argentina suggests that this genus was able to move into more temperace climes in that conitinent, something that it apparently never accompljshed in Nortin Anerica. Apparently the evolution from Kcaglievichia to Chlamytherium involved, among other things, an increased tolerance to colder wcainer, perhaps reflected by the greater size of Chlamytherium. Chlamytherium was able. later in the pleistocene, to disperse northwestward from the Gulf Coastal Plain and in Souih America it was able to spread southward throughout Argentina. It never, however. attain ea the widespread distribution on both continenis en joyed by G.lossotherium.

The genus Dasypus seems to have been more restrictur to tropical regions during the Blancan than were Glossotherim and Kraglicvichic. It, tco, was able to move out of the Gulf Coastai Plain later in the pleistocene, reaching as fiar wost as Texas and as far north as Missouri and oklahoma. The probable mecianism allowing for iolerance to coldou: weather may also have beer ar incrcase in sizc as ju chlis

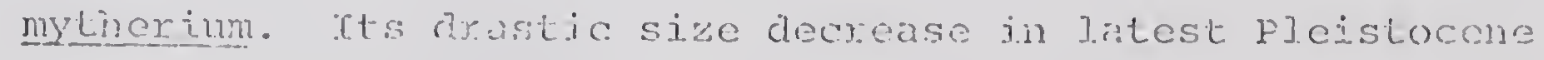


time (assuming D. bellus is ancestral to D. novemeinctus) could account for its present southern distsibution. Dasypus bellus is not known from South Americail fossil deposits although there is Iittle doubt that je originated there. This is good evidence that it was totally restricted to tropical areas on that continent, wrere fossil sites happen to be rare.

The unusual distributional pattern of petauria (early Pleistocene of Florida and Bavaria) indicates a wide cis-txibution complicated tooth group of flying squirrels. Apparontly this group was restricted to the eastern portion of North America while an alternate form existeo as an ecological equivalent in the west. James (1963) has reported flying squirrels of the simple tooth group ini deposits of western North America. 
SUMMARY

The Haile XVA mammais repxescrit a unique fama as it samples one of the few Gulf Coastal plain Blancan fauras, and is the only such faund which has been extensivel.y studical to date.

Among the important new pieces of information brought to light is the presence in North America of Glossotherinm chapadmalensis, which was heretofore known only from Argertina. It is possible that this form gave rise to G. I0.busius in South America and G. harlani in Nortir America. Apparently, Glossothorium was able to apread throughout North America while the other edentates represented in the Haile xVA fauna were restricted to the Gulf Coastal Plein throughout most of: the pleistocene.

The occuxrence of Kraglievichin paranensis at Haile XVA and Sania $F C I$ is the first record of this genus in North America. The presence of this species and of $r$. chanacimalensis strongthens the corrclation betweon North and South Aracican faunas of Blancar and Chapadmilatan?

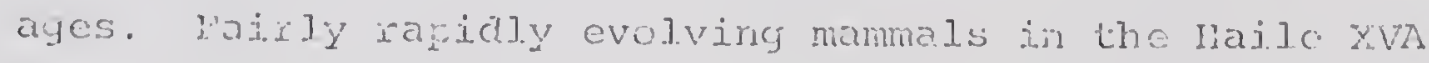


fauna which are corspecific with those in the chapadmajalan famn and in some of the Auricanean faunds are good evidence of closely similar ages.

The earliest know occurrence of Dasypus bellus is at Haile XVA. This creature undoubtedly originated in south America although its ancestors are not known. Further discovery of northern South American fossil deposits will more than likely turn up the ancestral forms as it was probably restricted to the equatorial portions of the continent where fossil deposits are rare.

The old world flying squirrel Petauria gives the fauna an unerpected lin\}: with the European faunas. The presence of this form refiects the Miocene or pliocene migration of European forms to North Ainerica (Simpson, 1947). That more remains of these forins are not known is probably due to the natural scarcity of small arboreal forms in the fossil record, as well as the possible restriction of this lincage of flying squirrels to the fores's of eastern North Anerica. Wine preseice of Pteronura in the Haile XVA fauna marks the first record of this large aquatic otter as a fossil. The possibility that the Haile XVA form was ancesiral to both Pteronurd and Lutra should be considered.

The preserice of ryylohyus rjoridanus at Haile XVA narks one of the eartiest records for this genus, though its 
anceston, Prosthenops, is known from the pliocenc. Platygonus occurs at santa Fe I, suggesting a difference in ecology

If the tontative assigninent of the Haile XVA camelici to Ilemiauchenia macrocephala is correct, it marks the cauliest record for this species anywhere. The typical Blancan species H. blancoensis occurs at Santa Fe I suggesting a possible age difference between the two localitics.

The remaining members of the Haile XVA fauna of fairly typical representatives of the North Amexicin Blancan (early Pleistocene) fauna. Such characteristic taxa as plesippus, Nannippus phlegon, and Sigmodon medius strengthen the assignment of a Blancen age to the fauna.

The presence of sharks and brackish water fishes indicates that the sea stood near Haile during the time that Haile XVA vas depositeả. Presumably this stand of the sea near 90 feet represents the Aftonian interglacial level. Although the bulk of the faura at Haile XVA represents an acuatic stream, an adjacont terrestrial community is also wej.l represented. Anong the mammals only pteronura and Castor represcnt the aquatic commuity. The terrostrial community includes several clear jndicators of a tropical forcst situation, these bejng Mylolyus, petauria, and the edeniates. 
I.ITERATURE CITED

Ikersien, W. A. 1970 Interpretation of sediments and vertehrate fossils in fili of Rea light bolson, southeastern Huaspeth County, Texas. Soc. Econ. Paleo. Miner. Permiar Basin Sec., 1970 Field Jrip Guidebooli, Publ. $70-12: \quad 82-87$.

Alt, D. and $\mathrm{H}$. K. Brooks. 1965 Age of the Florida marine terraces. Journ. Geol., 73(2): $406-411$.

Aneghino, F. 1375 Notas sobre algunos fosiles nuevos de la. Formacion Pampeana. Ameghino obras, 11: 13-17.

- 1887 Apuntes preliminares sobre algunos mamiferos extinguidos del yacimiento de Montehermoso existentes en el Museo de la Plata. Estracto, Entraga 1, Tomo I, Boletin Museo La Plata Imprenata, El Censos, $8: 339-353$.

1902 Notices preliminajres sur des maminifeies noveaux des terrains cretaces de Patagonie. Boletin de la Academia Nacinal de Ciencias de Cordoba, Iomo 1. $7: \quad 5-70$.

- 1904 IJuevas especies de mammiferos, cretacios y lerciarios, de la Republica Argentina, Ann. Soc. Cient: Arg., 16: 193-208.

Auffenberg, W. 1955 Glass lizards (Ophisaurus) from the pleistocene and pliocene of Florida. Herpetologica, 2: $133-136$.

$195 \%$ A note on ar unusually complete specimen of Dasypus bellus (Simpson) from Plorida. Quart. Jourr. Florida Aciu. Sci., 20(4): 233-237.

- 1958 Fossil turtes of the genus Terrapene in Florida. Rull. Jlorida state Mus., 3(2): 53-92. 
Bader, R. S. $19 ! 77$ Two Pleistorene mammil an faunas firom Alachua County. Florida. Buli. Hlorida stale Mus., $2(5): 53-75$.

Burbour, E. II. and C. B. Schultz. 1937 An carly plej.stocone fauna froln Nebraska. Amer. Mus. Novilates, No. 942: t- 10 .

Mrisson, M. J. 1762 regnum animale in classes IX distributum sive synopsis metlodica. Editio Altera. Leidon, rineodorum Haak: 1-295.

Brodkorb, P. 1963 A giant flightless bird from the pleistoccne of rlorida. Auk., 80(2): 111-115.

Bromn, M. 1838 Lethaea geognostica. Stuttgart, Vol. 2: $545-1350$.

Brown, B. 1903 A new genus of ground sloth from the Pleis... tocene of Nebraska, Paramy?odon nov. gell. Bull. Aner. Mus. Nat. Hist., 19: 569-583.

Cabrcra, A. 1929 Una revision de los mastociontes Argentinos. Rev. Mus. La Plata, 32: 61-141.

Castellanos, A. 1927 Breves notas sobre los clamiterios. publicacion Centre Estudiantes de Ingenierja de Rosario: $1-8$.

- 1937 Anotaciones soure 1 a linea filogenetica de los clamitcrios. Publicaciones de la fracultad de Ciencias de la Universidad Nacional del Litoral. Serie Tecnico-cientifica publicarion 8: 1-135.

1946 Una nueva especie de clamiterio Vassallia maxima n. sp. Publicaciones del Tnstituto de pisografia y Geolugia, Unjversidad Nacional. de Liloral, $6(26): 5-47$.

- 1957 iucvos goneros de clamiterio y de gervo y una nueva especic de plohophorus. Ameghiniana, 1(3): $5-14$.

Cooke, C.W. 1945 Gcology of Florida. Florida Geol. Surv. [3u] . 20: 1.-339. 
Cope, E. D. 1880 on the eximct cats oi America. Amer. Nautralist, 11: 838-858.

- $1892 \AA$ contribution to the vertebrate paleontology of mexas. Proc. Amer. Hhilos. Soc., 30: 123-13..

- 1893 A preliminary report on the vertebrate paleontology of the Ilano Estacado. Gcol. Surv. Texas Fourth injual Report: 1-136.

- 1839 Vertejorate remiins from Port Kennedy bone deposit. Journ. Acad. Nat, Sci. Phila., 11: 193-286.

Dawson, M. R. 1958 Later rertiary Leporiaje of Norti Mmeri-ca. Univ. Kan. Paleo. Contr., Vertebrata, 6: 1-75.

Dehm, R. 1962 Altoleistocane sauger von Schernfeld bei Eichstatt in Bayern. Munich. Bayerische Staatssanmlung für Palaontologie und Historisclue Geologie. ivitteilunsen, 2: 17-61.

Deperet, C. 1897 Les animaux pljocenes du Roussi11or. Mamoires de la Société Geologique de France, Paris. paleontologie, 3: 1-164.

Downs, T. and J. A. White. 1958 A vertebrate faunaI suc-.cesion in superposed sediments from late pliocene to middle pleistocene in california. 23 rd Int. Geol. Congress, 10: 41-4.7.

Frick, C. 1937 Fiormed ruminants of Nortin America. Amer. Mus. Nat. Hist. Bull. 69: 1-669.

Gazin, C. L. 1936 A stuay of the fossil horse remains from the upper Pliocene of Idaho. Proc. U. S. Nat. lius., $83(2985): 281-320$.

- 1942 The late Cenezoic vertebrate faunas from the San Pedro Valley, Arizona. Proc. U. S. Nat. Mus., $92(3155): 475-518$.

Gidley, J.W. 1922 preliminary report on fossil vertebrates of the San jedro Valley, Arizona. U. S. Gool. Surv., Prof. Paper 131-E: 119-131.

Gray: J. E. 1821 On the natiral arrangement of vertebrose aninals. Lordoil Med. Reposit., 15(1): 290-310. 
1837 Description of some new or little known Mammilia, principly in the British Muscum Collection. Mag. Nat. List. Now Series, 1: 577-587.

- 1867 Notics on the skulls of some lares (Lcpori.dac) and picas (Lagomyidae) in the British Muscum. Fnn. Mag. Nit. Hist., 20: 219-225.

Hal.], E R. and K. R. Knlson. 7959 The mammals of North America. The Ronald Press, New Yorti, 1-1079.

larlow, R. F. and $\mathrm{F}$. K. Jones. 1965 'l'he white-tajled decr in Florida. Florida Gane and Froshwater Fish Commis.. sion Tect. Buli. 9: 1-240.

Hay, O. P. 1917 Vertebrata mostly from stratum No. 3, Vero. Florida, togetler with descriptions of new speries. Florida Geol. Surv., 9th Annual Rept., 43-68.

1928 Again on pleistocene man at vero, Florida. Journ. Washington Acid. Sci., 18(9): 233-24l.

IIibbarả, C. W. 1937 An upper Pliocene fauna from Meacie County, Kansas. Trans. Kan. Acad. Sci., 40: 239.-265.

1941 Mammals of the Rexroad fauna from the upper Pliocene of southwestern Kansas. Trans. Kan. Acad. Sci., 44: 265-312.

Mibbard $C . W$. and $W . W$. Dalquest. 1962 Artiodactyls from the seymour Formation of Knox County, Texas. Pap. Mich. Acad. Sci.. 48: 83-99.

Hirschfeld, S. I. and S. D. Weblo. 1968 Plj.o-Pleistocene Miegalonyclid sloths of North America. Bull. Fla. state ius., 12(5): 213-296.

Hoffstetter, R. 1952. Los mammiferes pleistocenes de la Republique de i'Fguatour. Mem. Soc. Geol. France, $66: 1-391$.

Huguency, M. and P. Mein. 1966 Les rongemrs Plioconcs du Roussil] lon, dans colloctions Lyonnaises. Lyons Universice, haculté des sujences, Labaratoire de Geologie, Travaux, New Series, 13: 243-266. 
Janes, G T. 1957 Ar caentate from the plejstccene of Texas. Journ. Paleo, 31(4): 796-803.

1963 paieontology and nommarine stratigraphy of the Cuyama Valley badlanäs, Californio. Part. T. Geology, famal interpretations, and systematic descriptions of Chjroptera, Insectivora, and Rodentia. Univ. Calif. Publ. Ceol. Sci., 45: 1-154.

Kellogg, L。 1911. A fossil beaver from the Kettleman Hills. California. Univ. Calít. Publ., Bull. Dept. Geol., $6(17): 401-402$.

Kinsey, P. E. (in press) A new species of the peccary: Mylohyus, from tre early pleistocene of Florida.

Kraglievich, L. 1925 Cuacto nuevos gravigracios de la fauna araucana Chapadmalense. Anales del Museo Nacional de Historia Naturel, 33: 215-235.

- 1928 Mylodon darwinij Owen, es la especie genotipo de Mylodon owen. Rectificacion de la nomonclatura generica de los milodontes. Physis, 9: 169185.

- 1934. La antiquedad Piiocena de las fauras de Monte Hermoso y Chapadmalal, dediciáas desu comraracion con las que le precedieron y sucedieron. Montievideo, $1-136$.

- 1946 Sobre camelidos Chapadmalenses. Instituto del Museo de la Universidad Nacional de la plata. Notas del Museo de La Plata, Tomo 11. Paleontologia 93: $317-329$.

1918 Smilodontodoi riggi, n. gen.n. sp., un nuevo y pecrueno esmilodor: Chapadmale1. Revista del Nusec Argentina de Ciencjas Naturales, Ciencias zoologicus, $1(1): 1-44$.

Kretzoi, M. I959 Fama und famenhorizont von Csarnota. Jahresbericht cier Ungais chon Geologischen Anstali. $.1-395$.

Ieidy, J. I839a Description of the verteluate remains from pence Cacek, Florjad. Irans. Wagner Proc Irst. Sci.. $2: 19-32$. 
- 18801 rosisil vortrimatcis rom Florida. Proc. racad. Nat. Sci. phila., 96-97.

Linnacus, C. 1758 systema Naturac per reana tria naturae. secundum classes, ordines, generd, species cum chiracteribus, differentiis, symymis, locis. Editio decima, Reformata. Stocklojm, Laurentii Salvii, 1: 1-324.

Luna, P. W. 1838 B.li] paa Brasiliens Dyreverden for Siciste Jojdomvacltning. Overs. K. Dansíe Videnskeiernes Selskilis.. Porh., 8: 29-144.

Jundelius, E. I. 1960 Mylohyus masutus, long-nosed peccary of the rexas Pleistocene. bull. Texas Mem. lus., 1: 9- 40 .

MacNeil, F. S. 1949 pleistocene shorelines in plorida and Georgia. U. S. Geol. Surv., Prof. Paper 221-F: 95-107.

Martin, R. A. (in press) jossil mamnals fron the colcman IJA Local Fauma, Citrus County, Flonda.

McGrew, p. o. 1944 An early Pleistocene (Blancan) fauna ircu Nebraska. Field Mus. Nat. Hist., Gcol. Ser., 9(2): 33-66.

McKenna, M. C. 1962 Eupetaurus and the livirg petauristine sciurids. Amer. Mus. Novitates, no. 2104: I-38.

Merriam, J. C. and C. Stock. 1932 The Fejiclae of Rarcho Is Brea. Carnegie Inst. Wastrington Publ. 422: 3-231.

Morcno, F. P. and $A$. Mercerat. 1891 Exploraciois arcueoJogica de la Provincià de Catamarca. Paleontologica, en cichma misma Revista, del Museo de la plata, I: $2.22-2.34$.

Oesch, R. D. 1.967 A prelininary investigation of a pleistocone vertcbraie fauna from crankshift pit, Jefferson Comney, Missouri. National spoliological Soc. Bul1., $29(4): 363-185$.

Owen R. 1840 The zoology of the voyage of H. M. S. Beagle... Paid ?: Possil Mammitia. jondon. 13-111.

1842 boscristion of the skelcton of an ryinct oiganic sjoth, Mylodnm robustus Oren... Jondon. ]-i76. 
Patterson, B. and R. Pasqual. $I 968$ Evolution of mamals on southern continents. $V$. The fossil manmal fauna of

South America. The Quart. Rev. Biol., 43(4): 409-45t.

Patton, T. H. 1963 Fossil vertebrates from Miller's Cave, IIano County, Texas. Bull. Texas Mem. Mus., 7: 1-4l.

Paula Couto, C. de 1956 Resumo de memorias de Iuna sobre as cavernas de Lagoa santa e seu conteudo animal. Universidade do Brasij. Museu Nacional, publicacnes avulsas, 16: 1-14.

Porta T. de 1962 Edentata del Mioceno de La Venta (Colornbia). I Dasypodoidea y Glyptodontoidea. Boletin de Geologia, universidad Industrial de Santander, 10 : $5-23$.

Ray, C. E. 1957 A list, bibliography, and index of the fos.-. sil vertebrates of florida. Florida Geol. Surv., spec. publ. no. 3: 1-175.

Robertson, J. S. (in press) The fossil Bison of Florida:

Rovereto, C. 1914 Los estratos Araucanos y sus fosiles. Arales del Nuseo Nacional de Historia Naturel de Buoros Aires, 25: 1-236.

Savage, D. E. 1951 Late Cenozic vertebrates in the san Francisco Bay Region. Univ. Calif. Publ., Bull. Dept. Geol. Sci., 28(10): 215-314.

Schultz, J. R. 1938 A late cenezoic vertelorate fama from the Coso Mountains, Inyo County, California, Carnegie Inst. Washington Publ., no. 487: 76-109.

Sellaxds, E. H. 1915 Cliamytherium septentrionalis, ar edentate from the pleistocene of Florida. Amer. Journ. Sci., 4(40): 19-31.

- $\quad 193.7$ On the association of human remains and extinct vertebrates at Vero, Floxida. Journ. Geol., $25(1): 4-21$.

Simpson, G. G. 1928 pleistocene mamals from a cave in Citrus County, florida. amer. Mus. Novitates no. 328 : $1-16$. 
- 1929 Mlcistocene mammatian fauna of the Scminolc Ficld, pincllas county, Florida. Amer. Mus. ivat. Hist. Bul]., $56(8): 56]-599$.

1930 Holmesina sepicntrionalis, extinct giant armadilo of Forida. żmer. Mus. Novitates no. 42: $3-10$.

- 1945 The principles of classificalion and a classification of mannals. Bull. Amex. Mus. Nat. Irisi.., 85: $1-350$.

1947 Holarctic mammalian faumas and continenta?. relationships during the Cenozoje. Bull. Geol. Soc. iner., 58: 613-888.

Slaughter, B. H. 1961 The significance of Dasypus bellus (simpson) in Pleistocene local faunas. Texas Journ. Sci.., 13: $311-315$.

Stirton, R. A. 1935 A review of the Tertiary beavers. Uni. Calif. Publ., Buld. Dept. Geol., 23(13): 39j-458.

Stocis, $\therefore 1925$ cenorojc gravigrade edentates of westeril Nortin America, with special referene to the pleistocere Megalonychiciae and Mylocionticlae of Rancho La Brea. Camegie Inst. Washington Publ. no. 331: 1-206.

- 2928 Tanupolama, a now genus of llama from the ploistocene of California. Carnegie Inst. Washington [र(1) ], $10.393: 30-37$.

Strijn. W. S. 1966 Blancan mamalian fauna and lieistocene formatinns, Hudspeth County, 'fexas. Bull. Tcras Mem. tíns. 10: 1-55.

Sulinist:i, $\lambda .1964$ pliocene Ingomorpha and Rodentia from Werce ]. (Poland). Acta palaeontologica Polonica, Polska Akacionia Nauk, Fomitet Geologicany, 9(2): 149-240.

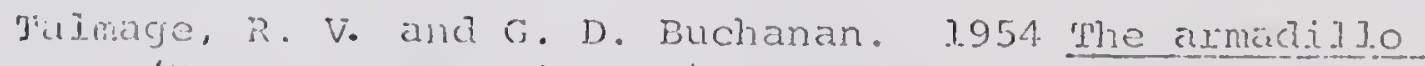
(Dasypus novenicinctus). A roviow of its natuxal history, enolngy, encatony, and relioductive physiology. The Rice Institnte Parmphiet, 4j(2): ]-135.

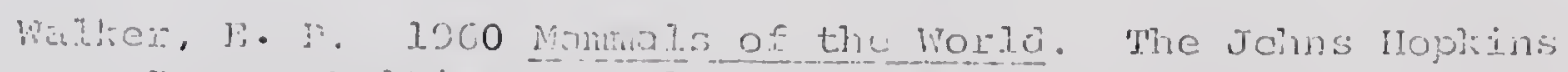

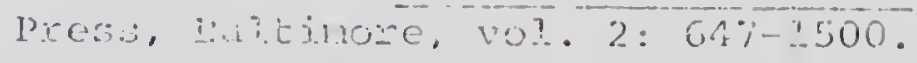


Weaver, W. G. and J. S. Robertson. 1967 A re-evaluation of fossit turties of the chrysomys scripta group. Tulane studies in Geology, 5(2): 53-66.

Weisb, S. D. (in press a) Chronology of pleictocene land mainmals in Florida.

- (in press b) pleistocene llarnas of plorida with notes on the lamini.

White, W. A. 1958 Some geomorphic features of central penin-sular Florida. Florida Geol. Surv, Geol. Bull. 4l: $1-42$.

Wiegel, R. 1962 Fossil vertebrates of Vero, Florida. F.jorida Geol. Surv., Spec. Publ. no. 10: 1.59.

Wilson, R. W. 1938 pliocene rodents of western North America. Carnegie Inst. Washington publ., no. 487: 22-73.

Winge, H. 1915 IordFundne og nulevende Gumlere (Edentata) fra Lagoa Santa, Minas Geraes, Brasilien. E. Museo Iundii, 3(2): 1-319.

Woodburne, M. O. 1966 Equid remains from the Sonoma VoIcanics, California. Bull. So. Calif. Acad. Sci., $65(3): 185-189$. 


\section{BIOGRAPHICAL, SKERCJ}

Jossc Stcadman Robertson, Jr., was born in St. Augustinc, Florida, on December 11, 1934. He attended public schools of New Smyina Beach and St. Iucie County righ School. He entered the United States Nary in 1952 and served fox four years. In 1956 he entered Jaclisorville Unirersity from which institution he was awarded a Bachelor of science degree in bjology in 1960.

He talght: in the public high suhoois for two yeais in Jacksonville and entered Graduate Schcol at the University cf Florida in 1962. He received a Master of Science degrou in zoology from this institution in 1965.

After another year in public high school teacining, ho joinca the faculty of Jacksonville University in 1966. In 1968 he again enrolled in the Graduate School at the Univeisjly of florida where he has been pursuing work toward a Jactor of Philosoplyy dogree.

lie is marrica to the former Miss Shirley Toyce Harth of Ner Ious, West Virginia, and has one som, Janny. 
He is à member of the society of vertebrate paleontologists, American Society of Mammajogists, Tri-reta Bio.logical Society, and The Anerican Association of University professurs. 
I certify that I have rowd this study and that in my opining it conforms to acceptable strincturds of scholarly

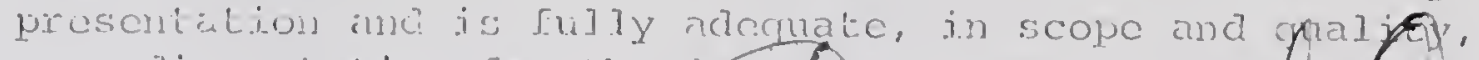

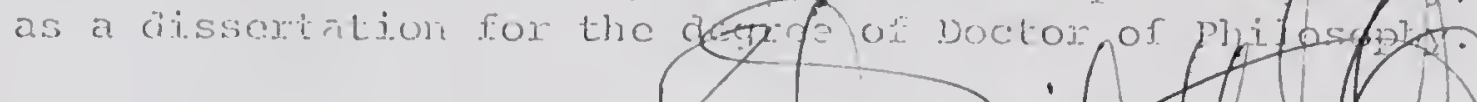

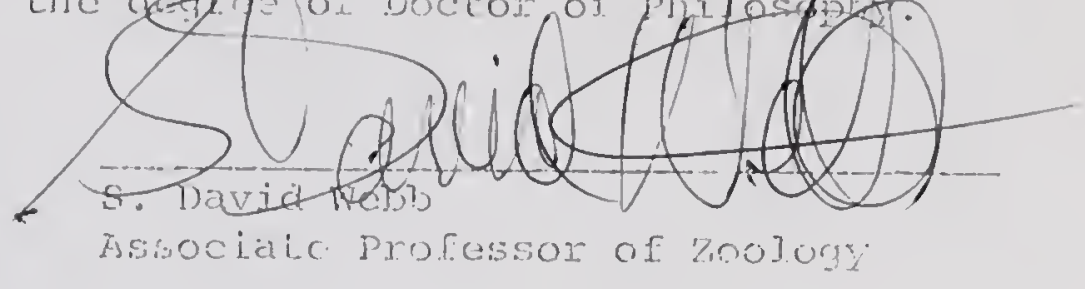

$x$ cortify that I llave read this study and that in liy opinjon it conformis to acceptable standands of seluolar yy prescutation and is fully adrquate, in scope and quality. as a disscitation for the degree of Doclor of prindosopliz.

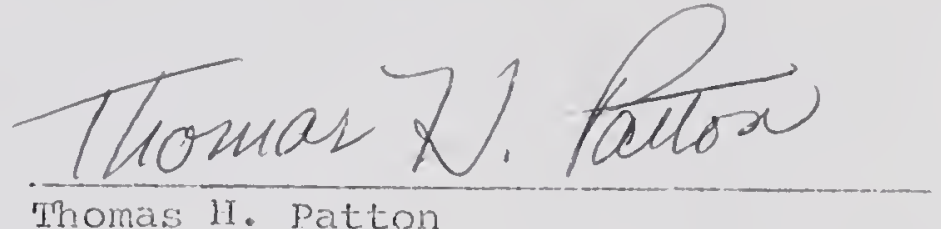

Associate professox of Zoology

I cortijy that I hare road this study and thai in my opinion it conforms to acrejtabie standards of acholat ly presentetion and is fully acequitc, in scope ard cuality. as a disscriation for the degree of Jocton of pritiosopiy.

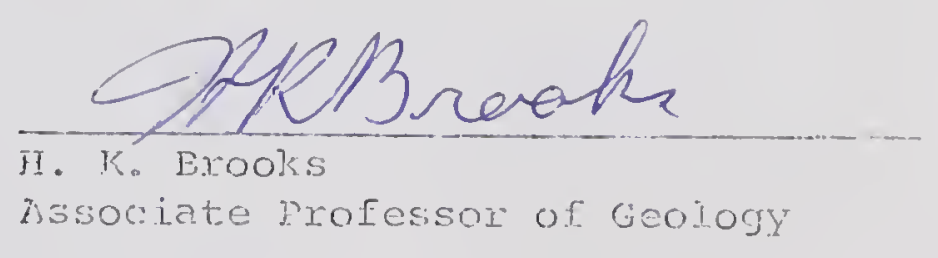

'his ainsertation was summitied to the Dean of the Collegc

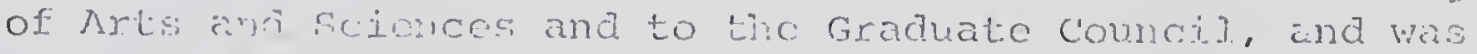
accepich as joritirl fulfilinent of the roguinemants for the degree of lortur of risilosophy.

Decemt:oi, $\quad 2379$

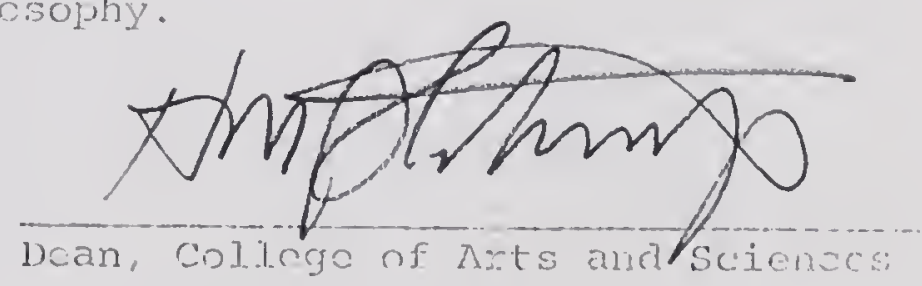


